\title{
A record of climatic changes in the Triassic palynological spectra from Poland
}

\author{
Anna FIJAŁKOWSKA-MADER ${ }^{1, *}$ \\ 1 Polish Geological Institute - National Research Institute, Holy Cross Mts Branch, Zgoda 21, 25-953 Kielce, Poland
}

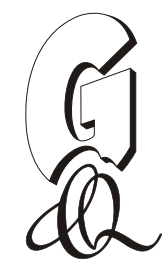

Fijałkowska-Mader, A., 2015. A record of climatic changes in the Triassic palynological spectra from Poland. Geological Quarterly, 59 (4): 615-653, doi: 10.7306/gq.1239

\begin{abstract}
Based on quantitative and qualitative analyses of Triassic miospore assemblages from different regions of Poland, climatic changes have been documented. The material came from published and archival works of Orłowska-Zwolińska and of the present author. It comprises ten palynological zones distinguished in the Triassic of Poland. Two different palynological methods were applied in this study - palyno-palaeoclimatic (PPC) model and sporomorph ecogroup (SEG) model - to obtain palaeoclimatic and palaeoenvironmetal data. The PPC model is based on the percent ratio of xerophytic and hygrophytic elements in miospore assemblages. Dominance of xerophytic elements (spores and pollen grains of xerophytic plants) indicates dry climate conditions, and a higher ratio of hygrophytic forms (spores and pollen grains of hygrohytic plants) reflects humid phases. A significant dominance of xerophytic elements in majority of the analysed assemblages suggests a dry climate during most of the Triassic. An increase of the number of hygrophytic elements is observed in the assemblages found in the Middle Buntsandstein, Upper Muschelkalk, Lower Keuper (Sulechów Beds), Schilfsandstein, Jarkowo Beds and Wielichowo Beds. It marks climate humidification in the Olenekian, Ladinian, Middle Carnian, Late Norian and Rhaetian, respectively. The SEG model, connecting dispersed spores and pollen with the floristic palaeocommunites that occupied determined ecological niches, was applied for palaeoenvironmetal interpretation. Four SEGs were recognized in the Triassic spore-pollen assemblages: Upland, Lowland and River, Coastal, and not attributed. The Uppland SEG dominates in these assemblages with exception of the spectra found in the Lower and Middle Buntsandstein, Upper Muschelkalk, Lower Keuper, Schilfsandstein, Jarkowo Beds and Wielichowo Beds, where the Lowland and River SEG occur more numerously.
\end{abstract}

Key words: miospores, climate, Triassic, palyno-palaeoclimatic (PPC) model, sporomorph ecogroup (SEG) model.

\section{INTRODUCTION}

Analysis of palynomorph assemblages in palaeoecological and palaeoclimatic studies is a common research tool. Despite effects of external factors, such as transportation or depositional environment, the palynomorphs assemblages reflect the composition of plant communities and, indirectly, the environmental changes caused by climatic fluctuations. Based on the analysis of assemblages from Carnian evaporites and coals, Visscher and Van der Zwan (1981) presented a palaeoclimatological model based on hygrophytic and xerophytic elements (spores and pollen), characteristic for humid and arid climates. Predominant xerophytic elements indicate an arid climate, prevailing hygrophytic ones - a humid climate. The xerophytic or hygrophytic character of miospores is determined by their botanical affinity (Table 1) and palaeoecology of the parent plants. Advanced studies on both teshe issues enabled to develop the model of Visscher and Van der Zwan (1981) (see Jelen and Kušej, 1982; Heunisch, 1990; Kustatscher et al., 2010). Since 1994, I have used this method in palynological studies of Triassic

\section{*E-mail: anna.mader@pgi.gov.pl}

Received: January 4, 2015; accepted: May 11, 2015; first published online: July 1,2015 deposits from Poland (Fig. 1) and proposed to call it the palyno-palaeoclimatic (PPC) model. This paper summarizes the results of application of the PPC model as well as the sporomorph ecogroup (SEG) model of Abbink (1998; Abbink et al., 2004a, b) for the Triassic miospore assemblages described by Orłowska-Zwolińska and the present author from epicontinental deposits of Poland. The author consistently uses the palynozonation after Orłowska-Zwolińska (1985) as it is the most suitable for the miospore assemblages from the Polish epicontinental basin. Differences in relation to the zones proposed by Kürschner and Herngreen (2010) for Central and NW Europe may result from the influences of the Siberian palaeofloristic province (see Dobruskina, 1994).

\section{GEOLOGICAL SETTING}

During the Triassic, the Polish part of the epicontinental Southern Permian Basin was temporally connected to the Boreal Sea and the Tethys (e.g., Feist-Burhkardt et al., 2008; Bachmann et al., 2010). The Early Triassic sedimentation of the Buntsandstein took place in fluvio-lacustrine environments influenced by short-time marine ingressions of the Boreal Sea in the Early Induan and Early Olenekian (Kopik and Senkowiczowa, 1973; Pieńkowski, 1991; Szyperko-Teller, 1997; Dadlez et al., 1998; Beutler and Szulc, 1999; Feist-Burhkardt et al., 2008; Bachmann et al., 2010; Figs. 2 and 3). In the Middle Tri- 
Quantitatively important Triassic miospore genera in the Polish assemblages and their botanical affinity

\begin{tabular}{|c|c|}
\hline Miospore genera & Botanical affinity \\
\hline Acanthotriletes & Filicales (Balme, 1995) \\
\hline Accinctisporites & Unknown botanical affinity \\
\hline Alisporites & $\begin{array}{c}\text { Coniferales: Podocarpaceae, Voltziaceae (Grauvogel-Stamm, 1978; Balme, 1995), Pteridosperms (De Jersey, } \\
\text { 1962; Van Konijnenburg-Van Cittert, 1971; Balme, 1995) }\end{array}$ \\
\hline Anapiculatisporites & Lycopodiales (Balme, 1995) \\
\hline Angustisulcites & Coniferales (Kürschner and Herngreen, 2010) \\
\hline Apiculatisporis & Filicales (Balme, 1995) \\
\hline Aratrisporites & $\begin{array}{c}\text { Lycopodiales: Izoetaceae, Selaginellaceae (Helby and Martin, 1965; Grauvogel-Stamm, 1978; } \\
\text { Grauvogel-Stamm and Duringer, 1983; Orłowska-Zwolińska, 1979, 1983; Mader, 1990b, 1997; Ruckwied, } \\
\text { 2009; Kürschner and Herngreen, 2010) }\end{array}$ \\
\hline Aulisporites & Equisetales (Orłowska-Zwolińska, 1983); Cycadales (Balme, 1995; Kustatscher et al., 2012) \\
\hline Baculatisporites & Filicales: Osmundaceae (Balme, 1995; Van Konijnenburg-Van Cittert, 2002) \\
\hline Brachysaccus & Coniferales (Orłowska-Zwolińska, 1979) \\
\hline Calamospora & Equisetales (Orłowska-Zwolińska, 1979; Kelber and Van Konijnenburg-Van Cittert, 1998) \\
\hline Camerozonosporites & Lycopodiales (Orłowska-Zwolińska, 1979) \\
\hline Camerosporites & Pteridosperms (Balme, 1995); Coniferales: Cheirolepidaceae (Scheuring, 1970; Visscher et al., 1994; Roghi, 2004) \\
\hline Carnisporites & Filicales (Roghi, 2004) \\
\hline Cedripites & Coniferales: Cedraceae (Potonié, 1967) \\
\hline Cerebropollenites & Coniferales: Taxodiaceae (Larsson, 2009) \\
\hline Chasmatosporites & Cycadales (Tralau, 1968; Kürschner et al., 2014), Ginkgoales (Balme, 1995) \\
\hline Conbaculatisporites & Filicales: Dipteridaceae (Pedersen and Lund, 1980; Roghi, 2004) \\
\hline Concavisporites & Filicales: Dicksoniaceae (Balme, 1995), Matoniaceae (Van Konijnenburg-Van Cittert, 1993; Roghi, 2004) \\
\hline Concentricisporites & Filicales (Kustatscher et al., 2010) \\
\hline Corollina (Classopolis) & Coniferales: Cheirolepidiaceae (Van Konijnenburg-Van Cittert, 1987; Balme, 1995) \\
\hline Cycadopites & Cycadales, Pteridosperms (Balme, 1995), Bennettitales (Kürschner et al., 2014) \\
\hline Cyclotriletes & Filicales: Osmundaceae (Mädler, 1964; Orłowska-Zwolińska, 1979, 1983) \\
\hline Cycloverrutriletes & Filicales (Orłowska-Zwolińska, 1979) \\
\hline $\begin{array}{l}\text { Deltoidospora } \\
\text { (Cyathidites) }\end{array}$ & $\begin{array}{l}\text { Filicales: Cyathaeaceae, Dicksoniaceae, Dipteridaceae, Marattiaceae, Matoniaceae, Schizeaceae (Douglas, } \\
\text { 1973; Van Konijnenburg-Van Cittert, 1989, 1993; Balme, 1995) }\end{array}$ \\
\hline Densoisporites & $\begin{array}{c}\text { Lycopodiales : Pleuromeiaceae (Knox, 1950; Lundblad, 1950, Yaroshenko, 1975; Orłowska-Zwolińska, 1979; } \\
\text { Meyen, 1987; Raine et al.,1988; Wang and Wang, 1990; Abbink, 1998; Looy et al., 2005) }\end{array}$ \\
\hline Densosporites & Lycopodiales: Selaginellaceae (Balme, 1995) \\
\hline Dictyophyllidites & Filicales: Dipteridaceae, Matoniaceae (Van Konijnenburg-Van Cittert, 1989, 1993; Balme, 1995) \\
\hline Duplicisporites & Coniferales: Cheirolepidiaceae (Visscher et al., 1994; Roghi, 2004) \\
\hline Echinitosporites & ?Filicales (Scheuring, 1970) \\
\hline Ellipsovelatisporites & Coniferales (Mader, 1997) \\
\hline Endosporites & Lycopodiales (Kürschner and Herngreen, 2010) \\
\hline Enzonalasporites & Coniferales (Balme, 1995; Visscher et al. 1994; Roghi, 2004) \\
\hline $\begin{array}{l}\text { Equisetumsporites } \\
\text { Eucommiidites }\end{array}$ & $\begin{array}{c}\text { Equisetales (Balme, 1995), Cycadales (Van Konijnenburg-Van Cittert, 1987; Balme, 1995), Erdtmannithecales } \\
\text { (Petersen et al., 2013),?Gnetales (Pedersen el al., 1989) }\end{array}$ \\
\hline Gleicheniidites & Filicales: Gleicheniaceae (Potonié, 1967) \\
\hline Granuloperculatipollis & Coniferales: Cheirolepidaceae (Orłowska-Zwolińska, 1983; Roghi, 2004) \\
\hline Heliosaccus & Coniferales: Cheirolepidaceae (Orłowska-Zwolińska, 1979) \\
\hline Heliosporites & Lycopodiales: Selaginellaceae (Orłowska-Zwolińska, 1979) \\
\hline $\begin{array}{l}\text { Illinites } \\
\text { (Succinctisporites) }\end{array}$ & $\begin{array}{c}\text { Coniferales: Lebachiaceae (Orłowska-Zwolińska, 1979, 1983; Balme, 1995), Voltziaceae (Grauvogel-Stamm } \\
\text { and Grauvogel, 1973), Pteridosperms (Kürschner and Herngreen, 2010) }\end{array}$ \\
\hline Infernopollenites & Coniferales (Visscher et al., 1994; Roghi, 2004) \\
\hline Keuperisporites & Unknown botanical affinity \\
\hline Klausipollenites & Coniferales: Voltziaceae (Potonié, 1967) \\
\hline
\end{tabular}


Tab. 1 cont.

\begin{tabular}{|c|c|}
\hline Miospore genera & Botanical affinity \\
\hline Kraeuselisporites & Lycopodiales (Balme, 1995; Roghi, 2004; Kürschner and Herngreen, 2010) \\
\hline Kugelina & Coniferales: Cheirolepidaceae (Roghi, 2004) \\
\hline Labiisporites & Coniferales: ?Voltziaceae (Orłowska-Zwolińska, 1983) \\
\hline Leschikisporis & Filicales: Marattiaceae (Orłowska-Zwolińska, 1983; Balme, 1995) \\
\hline Lunatisporites & $\begin{array}{c}\text { Coniferales: Podocarpaceae (Clement-Westernhof, 1974; Visscher et al., 1994; Balme, 1995), Pteridosperms } \\
\text { (Looy et al., 2005) }\end{array}$ \\
\hline Lundbladispora & $\begin{array}{c}\text { Lycopodiales: Pleuromeiaceae (Yaroshenko, 1975; Orłowska-Zwolińska, 1979; Kürschner and Herngreen, } \\
\text { 2010; Looy et al., 2005) }\end{array}$ \\
\hline Lycopodiacidites & Lycopodiales (Filatoff, 1975; Abbink, 1998) \\
\hline Lycopodiumsporites & Lycopodiales (Filatoff, 1975) \\
\hline Marattisporites & Filicales: Marattiaceae (Orłowska-Zwolińska, 1983) \\
\hline Microcachryidites & Coniferales: Podocarpaceae (Balme, 1964, 1995) \\
\hline $\begin{array}{l}\text { Minutosaccus } \\
\text { (Protodiploxypinus) }\end{array}$ & Coniferales: Voltziacae (Kürschner and Herngreen, 2010) \\
\hline Monosulcites & $\begin{array}{c}\text { Cycadales, Bennettitales (Potonié, 1967; Van Konijnenburg-Van Cittert, 1971; Boutler and Windle, 1993), } \\
\text { Ginkgoales (Van Konijnenburg-Van Cittert, 1971) }\end{array}$ \\
\hline Nevesisporites & Lycopodiales (Kustatscher et al., 2010) \\
\hline Osmundacidites & Filicales: Osmundaceae (Van Konijnenburg-Van Cittert, 1978) \\
\hline Ovalipollis & Coniferales: Voltziaceae (Scheuring, 1970; Orłowska-Zwolińska, 1979; Roghi, 2004) \\
\hline Palaeospongisporis & Unknown biological affinity \\
\hline Parillinites & Coniferales (Balme, 1995) \\
\hline $\begin{array}{l}\text { Partitisporites } \\
\text { (Paracirculina) }\end{array}$ & Coniferales: Cheirolepidaceae (Orłowska-Zwolińska, 1979, 1983; Visscher et al., 1994; Roghi, 2004) \\
\hline Perinopollenites & $\begin{array}{c}\text { Coniferales: Taxodiaceae/Cupressaceae (Balme, 1985; Van Konijnenburg-Van Cittert and Van der Burgh, } \\
\text { 1989; Van Konijnenburg-Van Cittert, 2002; Larsson, 2009) }\end{array}$ \\
\hline Perotrilites & Unknown biological affinity \\
\hline Platysaccus & Coniferales: Podocarpaceae (Balme, 1995) \\
\hline Podosporites & Coniferales: Podocarpaceae (Orłowska-Zwolińska, 1983; Balme, 1995; Kürschner and Herngreen, 2010) \\
\hline Polypodiumsporites & Filicales: Polypodiaceae (Balme, 1995) \\
\hline Porcellispora & Mosses (Mader, 1997; Reinhardt et Ricken, 2000; Roghi, 2004) \\
\hline Praecirculina & Coniferales: Cheirolepidacae (Kürschner and Herngreen, 2010) \\
\hline Protohaploxypinus & Coniferales (Orłowska-Zwolińska, 1983), Pteridosperms (Balme, 1995) \\
\hline Puntatisporites & Filicales: Marattiaceae, Osmundaceae (Grauvogel-Stamm and Grauvogel, 1980) \\
\hline Rhaetipollis & Coniferales (Larsson, 2009) \\
\hline Riccisporites & $\begin{array}{l}\text { Mosses: Marchanteaceae (Lundblad, 1954; Balme, 1995), Gymnosperms (Orłowska-Zwolińska, 1979, 1983), } \\
\text { Conifers (Rhotwell et al., 2000; Vajda et al., 2013), ?Bennettitales (Mander et al., 2012; Kürschner et al., 2014) }\end{array}$ \\
\hline Sphaeripollenites & Coniferales: Taxodiaceae, Cheirolepidiaceae (Abbink, 1998) \\
\hline Sphagnumsporites & Mosses (Filatoff, 1975) \\
\hline Striatoabietites & Coniferales (Scheuring, 1970; Meyen, 1981, 1987), ?Pteridosperms (Kustatscher et al., 2010) \\
\hline Todisporites & Filicales: Osmundaceae (Orłowska-Zwolińska, 1983; Balme, 1995) \\
\hline Toroisporis & Filicales (Roghi, 2004) \\
\hline Trachysporites & Filicales (Bonis, 2010) \\
\hline Triadispora & $\begin{array}{c}\text { Coniferales: Albertiaceae, Voltziaceae (Grauvogel-Stamm, 1969, 1978; Orłowska-Zwolińska, 1979, 1983; } \\
\text { Balme, 1995; Brugman, 1986; Visscher et al., 1994; Kürschner and Herngreen, 2010) }\end{array}$ \\
\hline Tsugaepollenites & Pteridosperms (Kürschner and Herngreen, 2010) \\
\hline Uvaesporites & Filicales (Roghi, 2004), Lycopodiales: Pleuromeiaceae (Looy et al., 2005) \\
\hline Verrucosisporites & Filicales: Marattiaceae, Osmundaceae (Orłowska-Zwolińska, 1979; Balme, 1995) \\
\hline Vitreisporites & $\begin{array}{c}\text { Ginkgoales: Caytoniaceae (Van Konijnenburg-Van Cittert, 1971; Balme, 1995); Bennettitales (Van } \\
\text { Konijnenburg-Van Cittert, 2008), Pteridosperms (Mander et al., 2011) }\end{array}$ \\
\hline Voltziacaesporites & Coniferales: Voltziaceae (Balme, 1995) \\
\hline Zebrasporites & Filicales (Petersen et al., 2013) \\
\hline
\end{tabular}




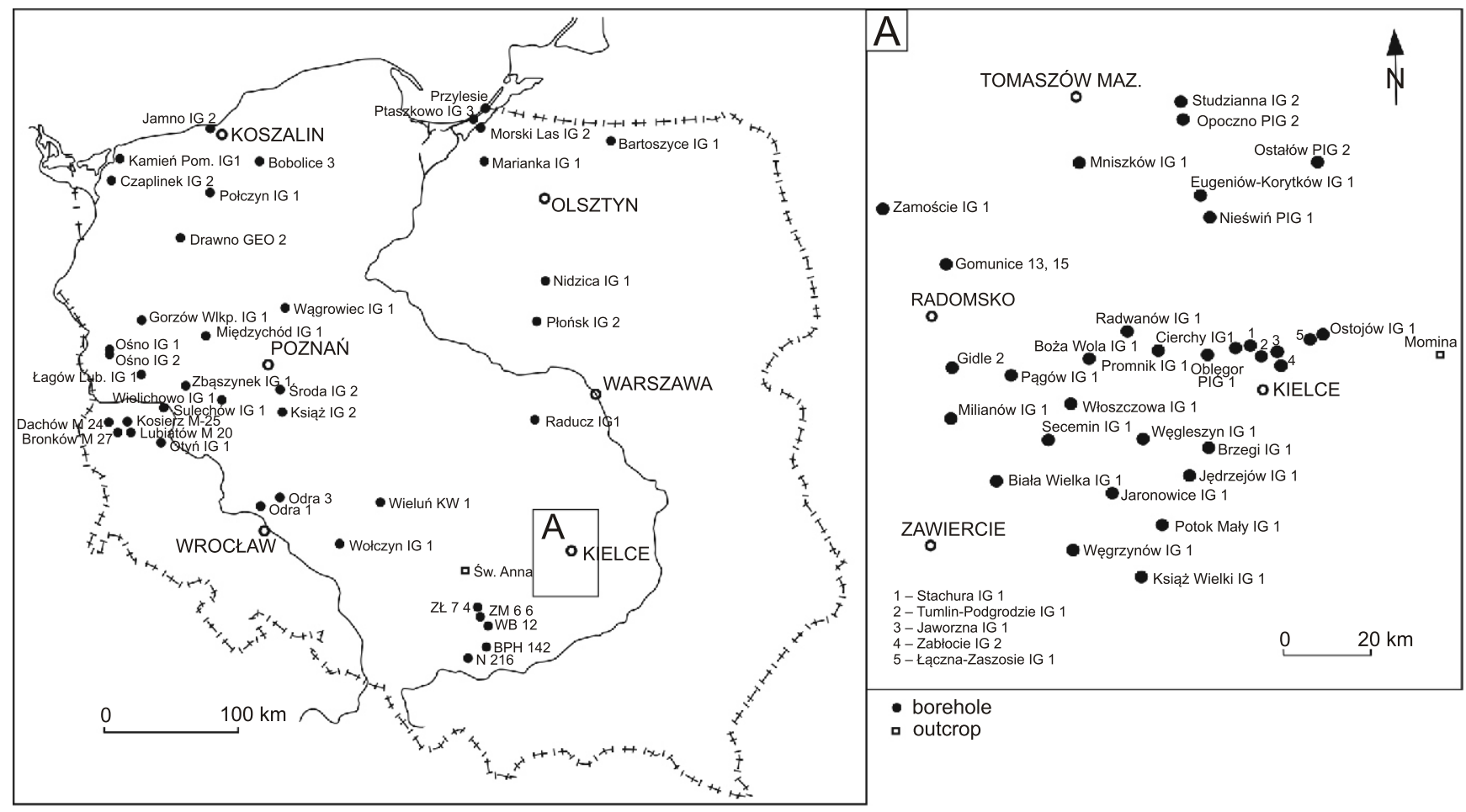

Fig. 1. Location of the studied boreholes and outcrops

assic the Polish Basin was open toward the south and temporally connected with the Tethys, which resulted in marine sedimentation of the Röt and Muschelkalk in the Anisian and Early Ladinian (Figs. 4 and 5). The author correlates the Röt deposits to Early Anisian based on the occurrence of the Anisian pollen Stellapollenites thergartii (Mädler) Brugman in miospore assemblages found in the Röt deposits (see also Feist-Burkhardt et al., 2008: fig. 13.1; Lucas, 2010: fig. 3). In the Late Ladinian, the marine basin was replaced by an alluvial plain with lakes and swamps, where the Lower Keuper Sulechów Beds (Lettenkohle) originated, surrounded by areas with fluvial sedimentation (Fig. 6). The latest Ladinian transgression resulted in deposition of the Grenzdolomit. Subsequently, the Polish Basin lost definitely its connection to the Tethys, and deposition of the Lower Gipskeuper occurred in hypersaline lagoon, sabkha and playa environments (Gajewska et al., 1985; Dadlez et al., 1998; Feist-Burkhardt et al., 2008; Bachmann et al., 2010; Fig. 7). During the Middle Carnian (Julian), the Schilfsandstein sedimentation took place in fluvial, deltaic and lacustrine environments (Gajewska, 1977; Szulc, 2000; Fig. 8). In the latest Carnian, evaporitic sedimentation of the Upper Gipskeuper was restricted to the central part of the Polish Basin, whereas fluvial deposition dominated in the adjacent areas (Dadlez et al., 1998). The later, Norian marine ingression resulted in deposition of the lowest part of the Jarkowo Beds. The upper part of the Jarkowo Beds and the Zbąszynek Beds were deposited in varied continental environments - mudflats, lakes, swamps and ephemeral streams with weak marine influences especially in the upper part of the Zbąszynek Beds (Deczkowski, 1997; Dadlez et al., 1998; Fig. 9). Similar sedimentation in fluvial and lacustrine environments continued in the Rhaetian (Feist-Burkhardt et al., 2008; Bachmann et al., 2010; Fig. 10).

\section{MATERIAL AND METHODS}

The analysis covered 172 miospore assemblages in 605 samples from 71 boreholes and two outcrops (Figs. 1-10; Appendix $\left.1^{*}\right)$. They represent 10 miospore zones distinguished in the Triassic deposits of Poland by Orłowska-Zwolińska (1985; Fig. 11). In majority of samples, 100 sporomorphs have been counted for quantitative analyses. The palaeoclimatic interpretation of palynomorph assemblages was done with the slightly modified palaeoclimatological model of Visscher and Van Der Zwan (1981) (I proposed the term "palyno-palaeoclimatic model" - PPC model). In this model, sporomorphs are divided into the following 18 morphogroups: $\mathrm{A}$ - alete and monolete spores, B - trilete laevigate and apiculate spores, C - trilete verrucate, reticulate and murornate spores, $D$ - trilete zonate and cingulate spores (excluding Densoisporites specimens), E - Aratrisporites spp., and F - Porcellispora spp., which represent hygrophytic elements; $\mathrm{H}$ - monosulcate pollen, I - Illinites spp., Parillinites spp., and $\mathrm{J}$ - asaccate pollen (excluding circumpollen), which are intermediate elements; $\mathrm{K}$ - Ovalipollis spp., $\mathrm{L}$ - alete bisaccate pollen, $\mathrm{M}$ - taeniate bisaccate pollen, $\mathrm{N}$ - Triadispora spp., $\mathrm{O}$ - trilete bisaccate pollen, $\mathrm{P}$ - vesicate pollen, $\mathrm{R}$ - monosaccate pollen, and $\mathrm{S}$ - circumpollen, which represent xerophytic elements. There is one "problematic" group G consisting of the Early Triassic spores of Densoisporites produced by lycopsid Pleuromeia, a succulent bushy quillwort (Orłowska-Zwolińska, 1979; Meyen, 1987; Grauvogel-Stamm, 1999) characterized by wide environmental tolerance (Mader, 1990a). Van der Zwan and Spaak (1992), Galfetti et al. (2007) and Hochuli and Vigran (2010) included it to xerophytic forms, whereas Yaroshenko (1977) considered it to be a hygrophytic element. To solve this problem, group $\mathrm{G}$ was placed into intermediate elements in the PPC model. 


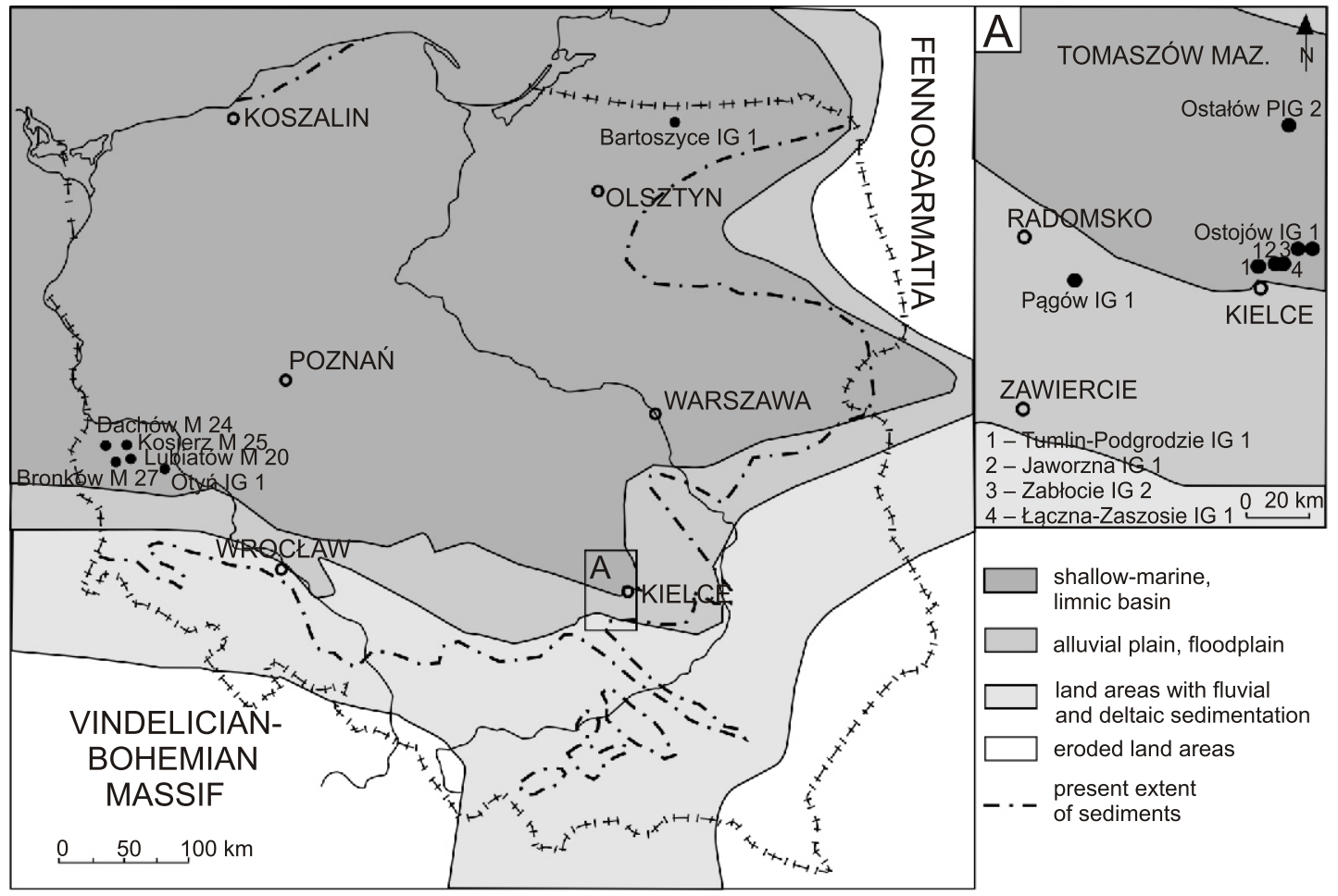

Fig. 2. Palaeogeographic map of the Lower Buntsandstein basin (after Szyperko-Teller, 1977; Dadlez et al., 1998; Kuleta and Zbroja, 2006; Feist-Burkhardt et al., 2008) with location of the boreholes containing miospore assemblages of the obsoleta-pantii zone

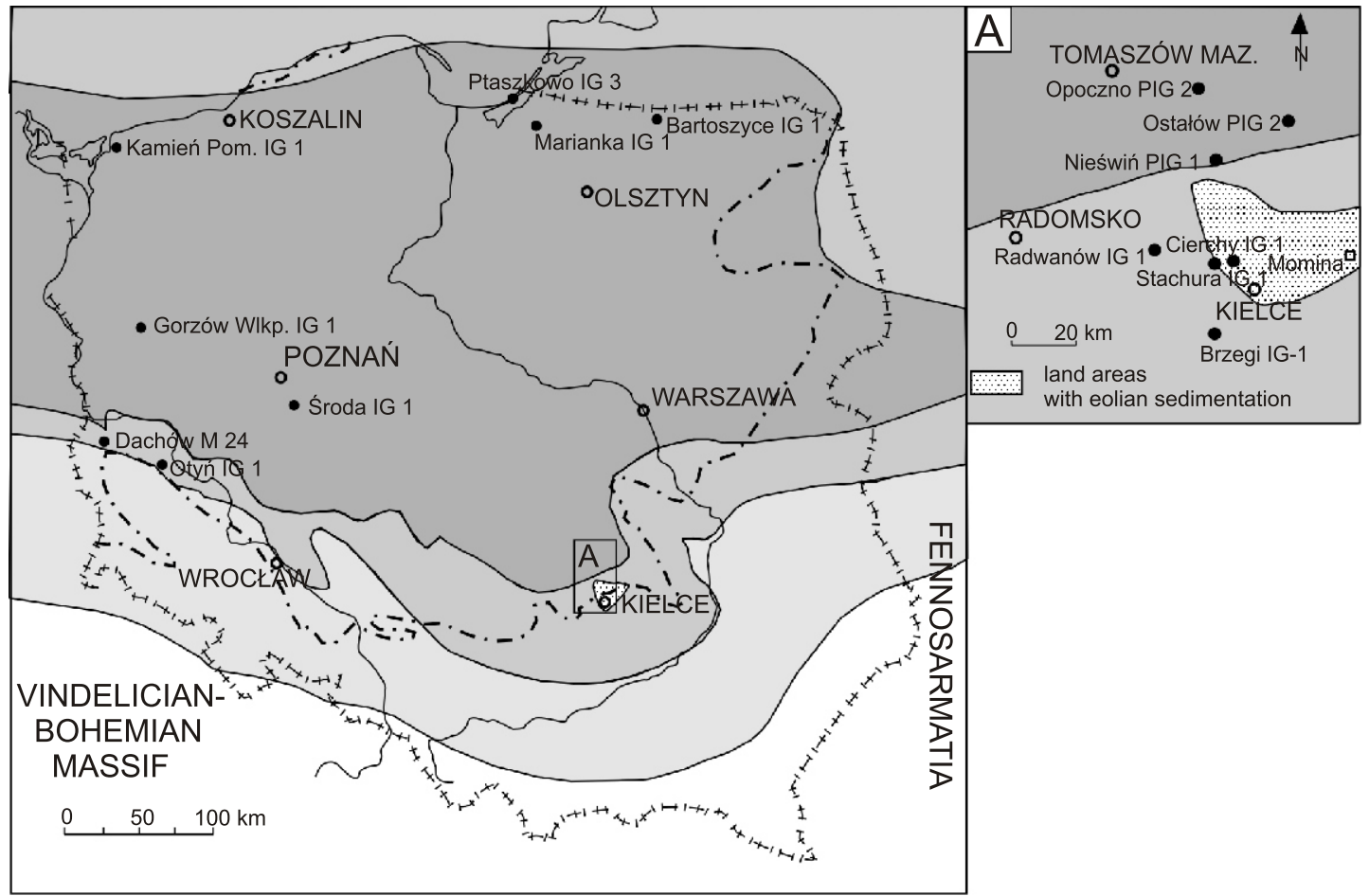

Fig. 3. Palaeogeographic map of the Middle Buntsandstein basin (after Dadlez et al., 1998) with location of the boreholes containing miospore assemblages of the nejburgii zone 


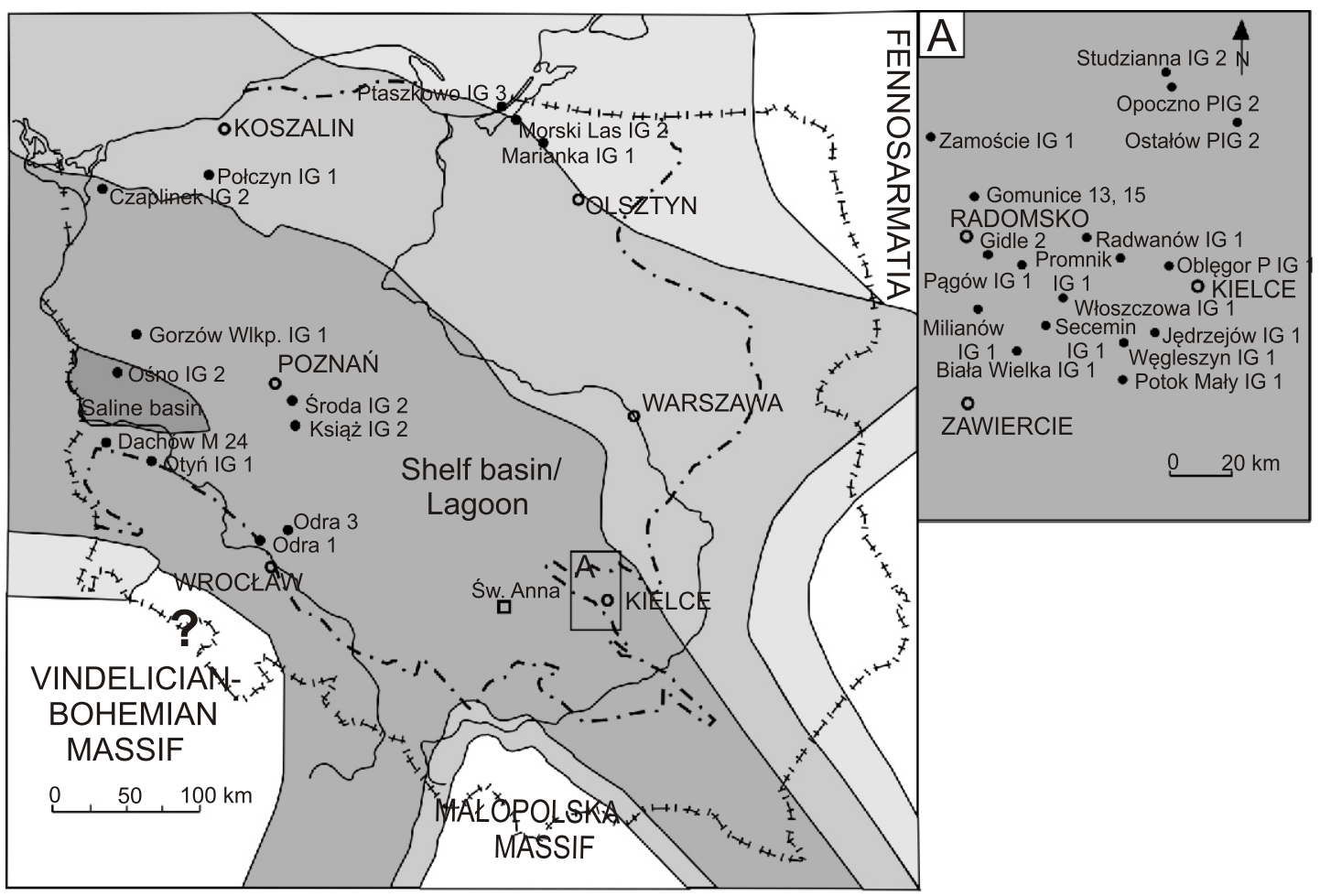

Fig. 4. Palaeogeographic map of the Röt basin (after Dadlez et al., 1998; Feist-Burkhardt et al., 2008) with location of the boreholes containing miospore assemblages of the heteromorphus zone

Other explanations as in Figure 2

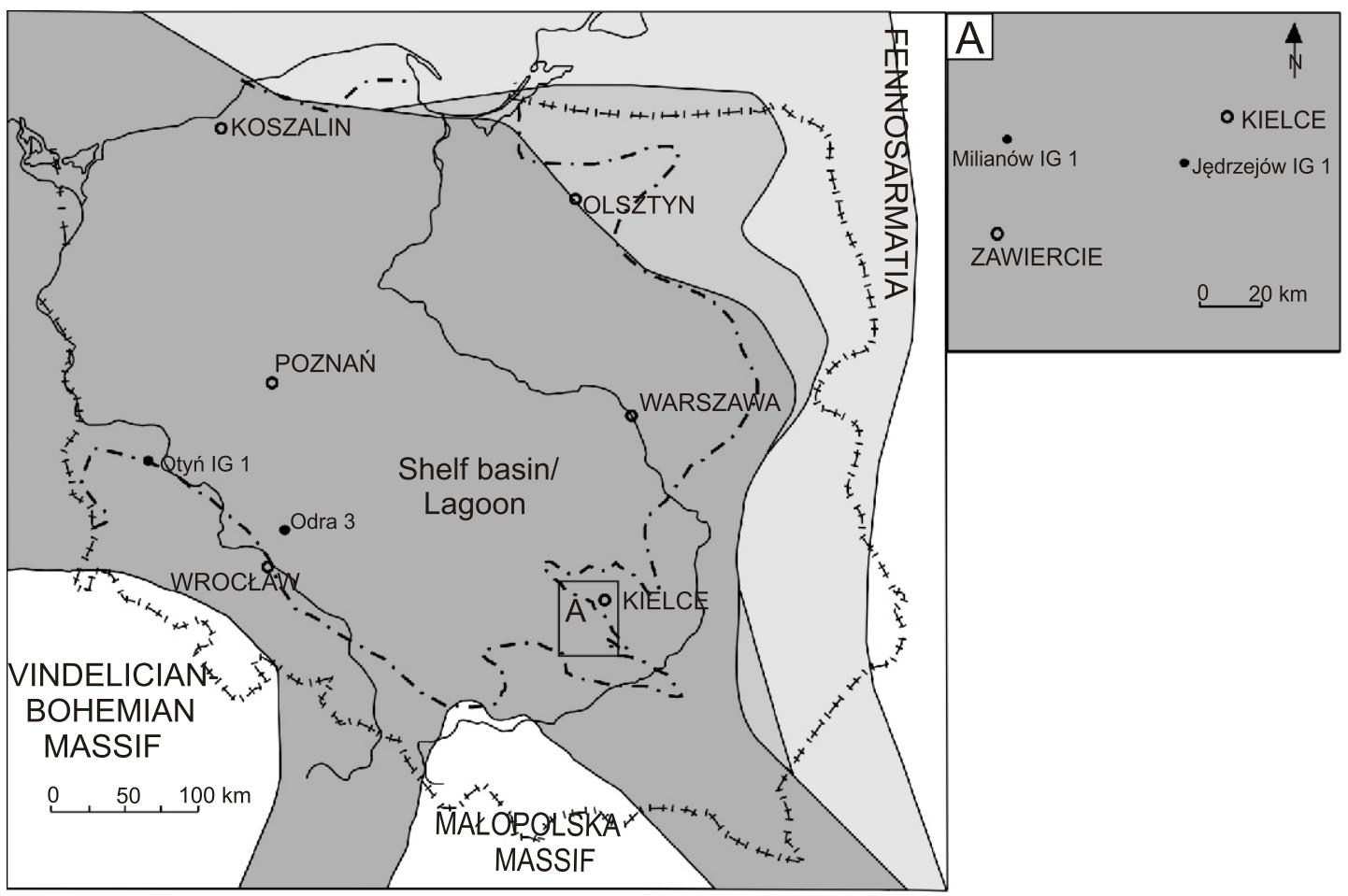

Fig. 5. Palaeogeographic map of the Lower Muschelkalk basin (after Szulc, 2000; Feist-Burkhardt et al., 2008) with location of the boreholes containing miospore assemblages of the minor zone 


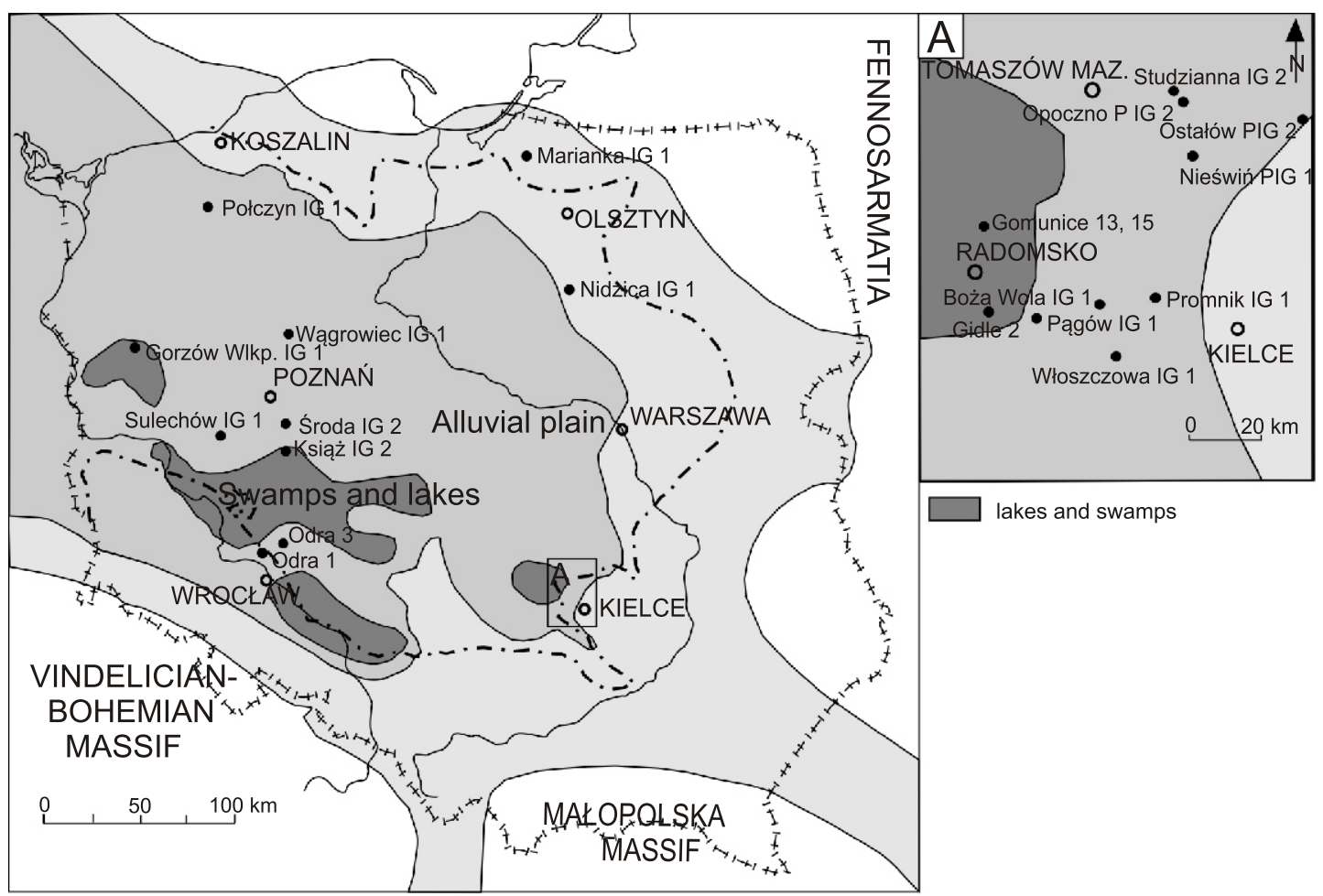

Fig. 6. Palaeogeographic map of the Lower Keuper basin (after Dadlez et al., 1998) with location of the boreholes containing miospore assemblages of the dimorphus zone

Other explanations as in Figure 2

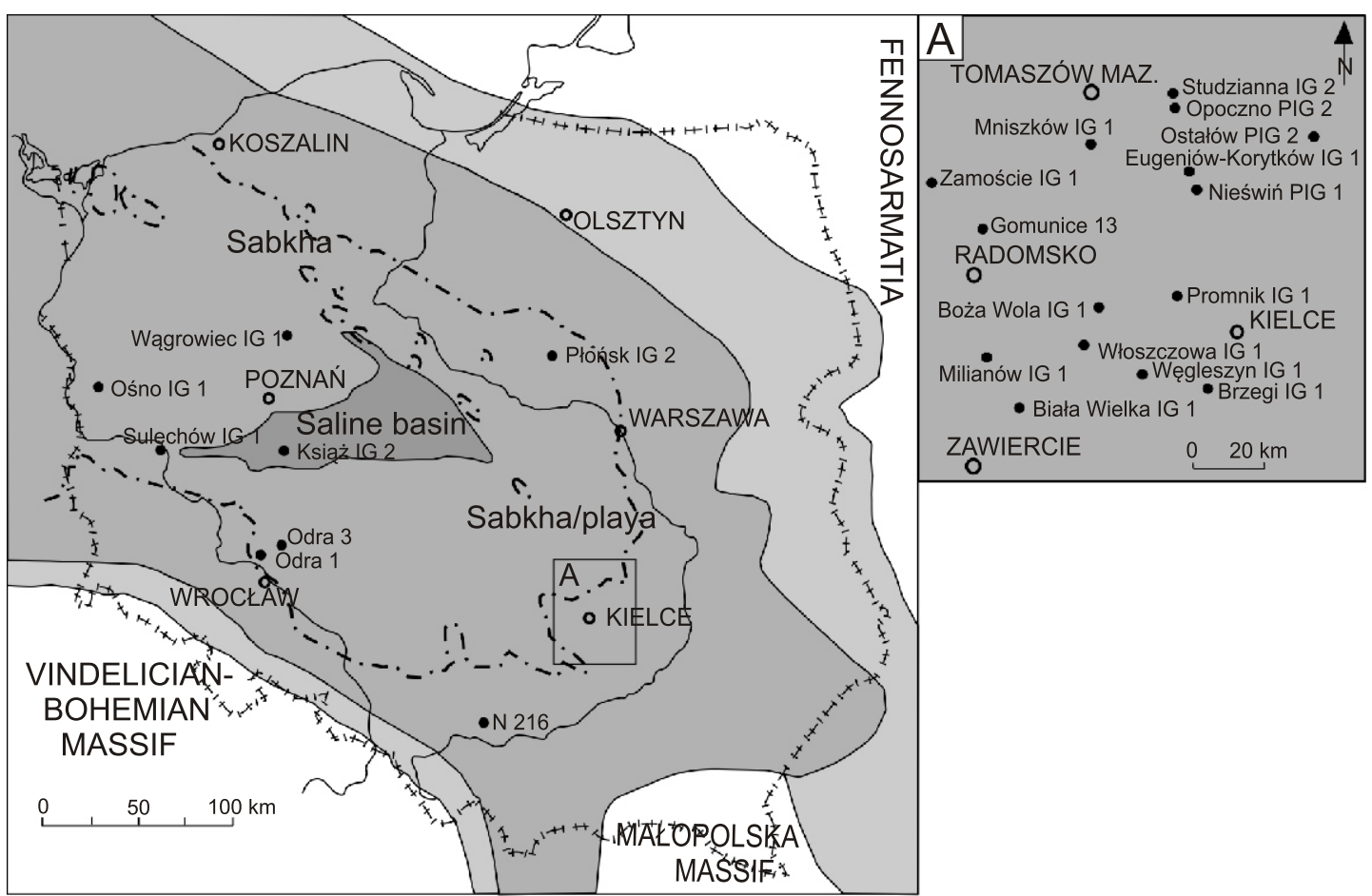

Fig. 7. Palaeogeographic map of the Lower Gipskeuper basin (after Dadlez et al., 1998; Feist-Burkhardt et al., 2008) with location of the boreholes containing miospore assemblages of the longdonensis zone 


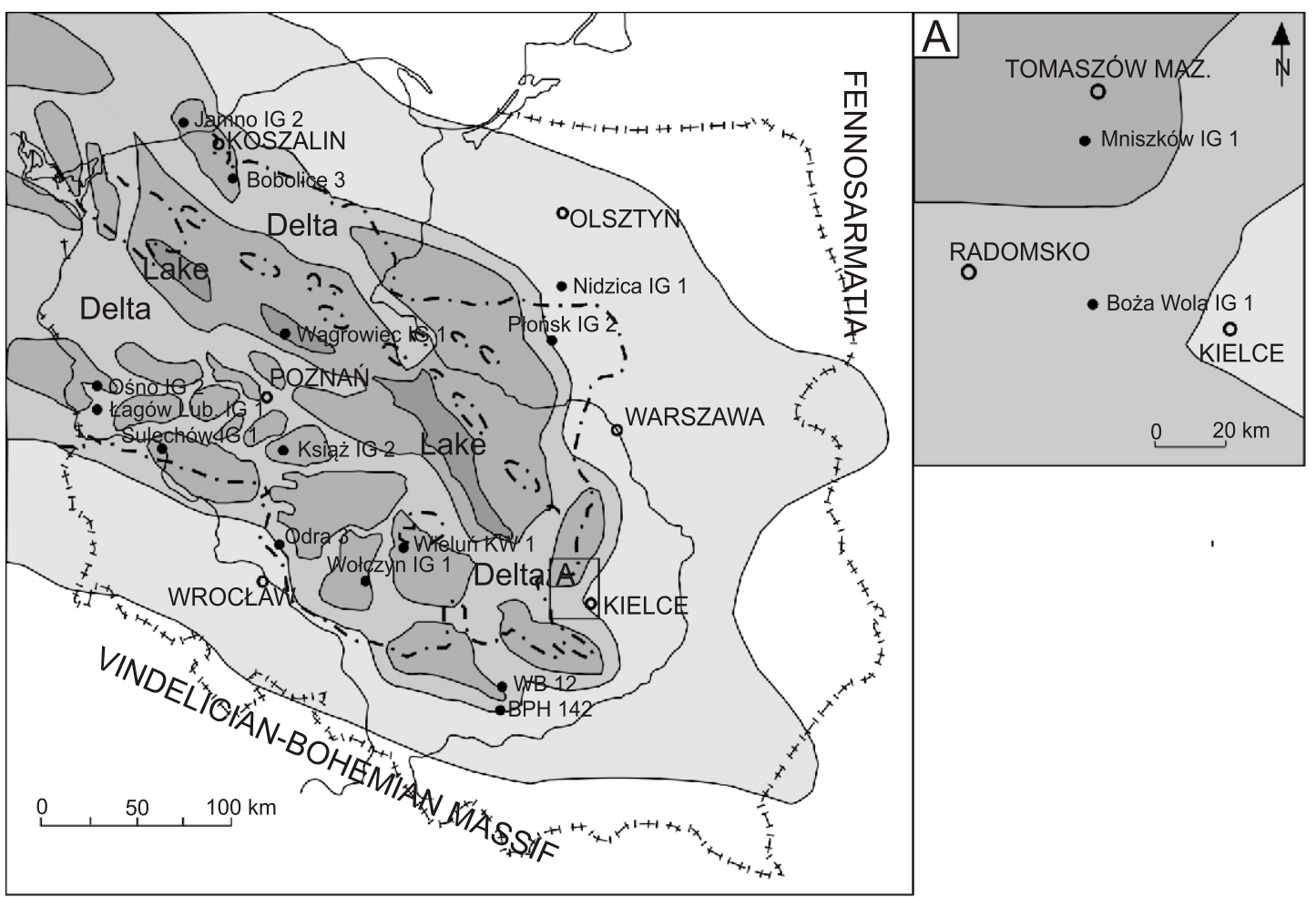

Fig. 8. Palaeogeographic map of the Schilfsandstein basin (after Dadlez et al., 1998) with location of the boreholes containing miospore assemblages of the astigmosus zone

Other explanations as in Figure 2

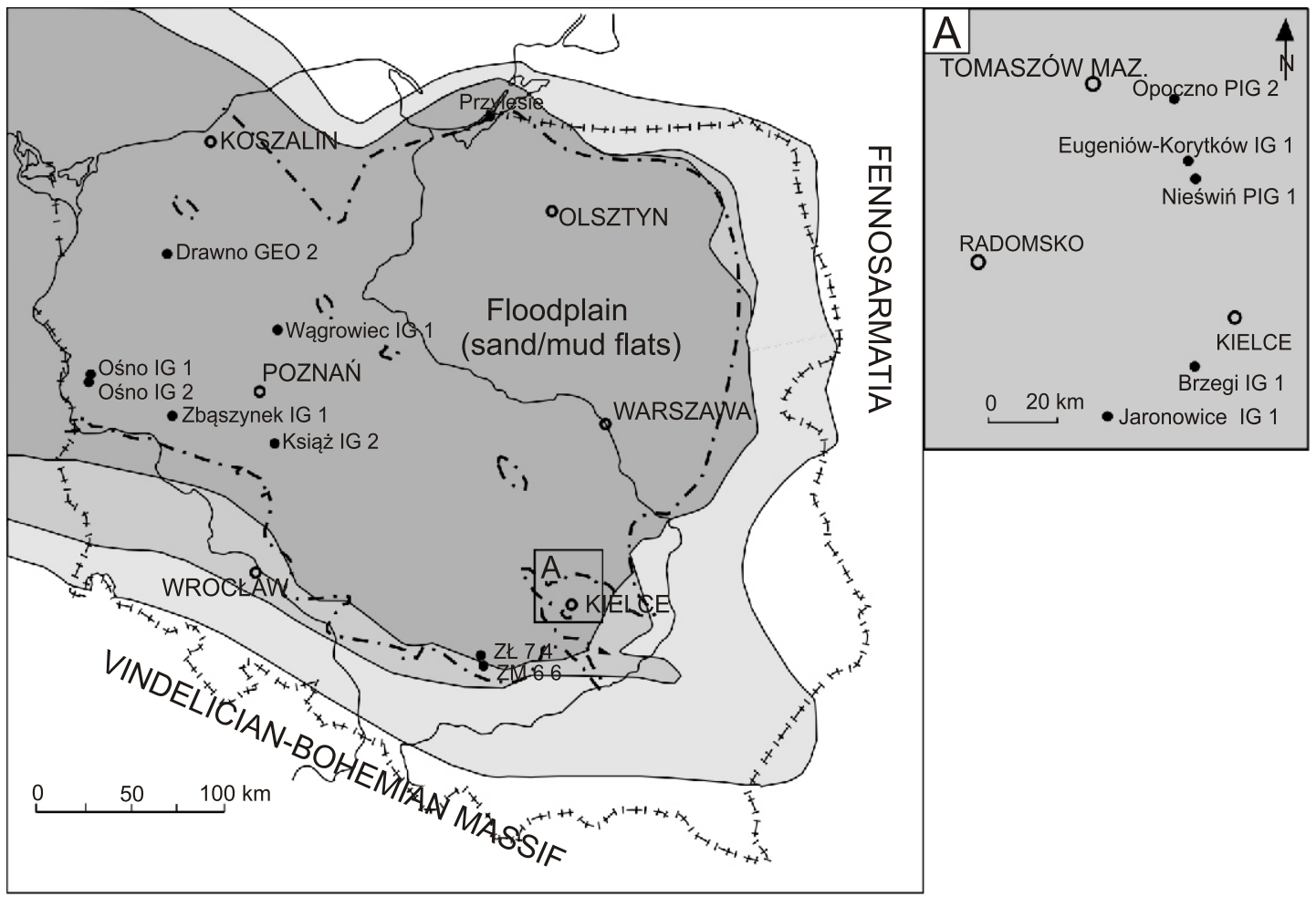

Fig. 9. Palaeogeographic map of the Jarkowo Beds basin (after Dadlez et al., 1998) with location of the boreholes containing miospore assemblages of the meyeriana zone 


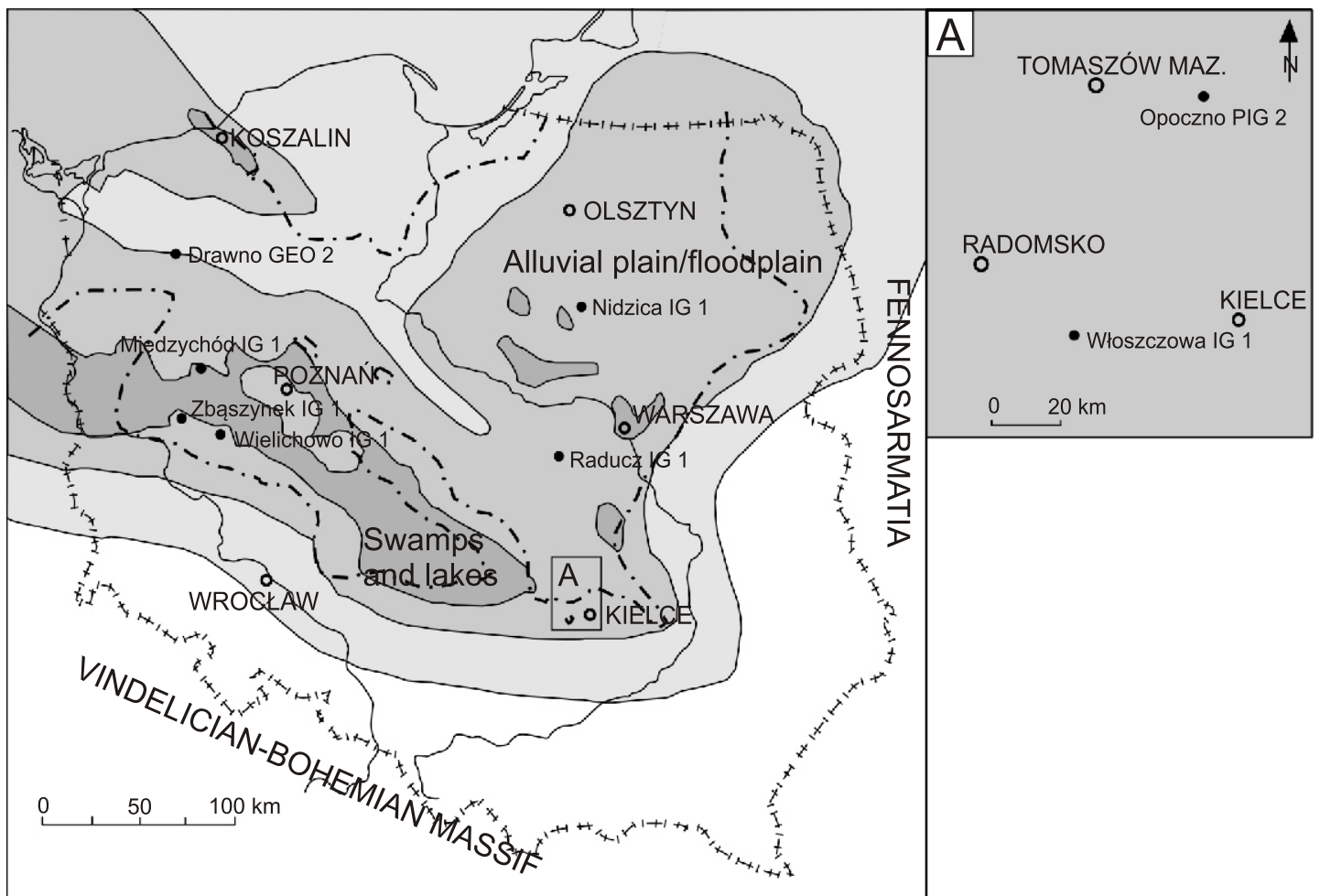

Fig. 10. Palaeogeographic map of the Wielichowo Beds basin (after Dadlez et al., 1998) with location of the boreholes containing miospore assemblages of the tuberculatus zone

Other explanations as in Figure 2

Palaeoclimatic interpretations were obtained from the ratio of xero- and hygrophytic forms.

Moreover, the SEG model presented by Abbink (1998; Abbink et al., 2004a, b), which connects dispersed spores and pollen with the floristic palaeocommunites that occupied specific ecological niches, was applied for palaeoenvironmetal interpretation. The model is based on the ecological preferences of extinct parent plants determined after actualistic principles as well as features of sediments in which the sporomorphs were found. Four SEGs were recognized in the Triassic spore-pollen assemblages: Upland (U.S.), Lowland and River (L.R.+R.S), Coastal (C.S.), and not attributed (n.a.). Attribution of the sporomorph genera to the different SEGs is presented in Table 2. The Coastal and Land SEGs (c/l) ratio was counted. In addition, the particular miospore species and genera in the Lowland SEG indicate palaeoenvironmental conditions such as "dry" or "more wet", "warmer" or "cooler". In case of the Triassic miospores, these taxa indicators can be applied to determine a wet and/or dry environment (w/d ratio). According to Abbink (1998; Abbink et al., 2004a: p. 20-21), changes that occur especially within the Lowland SEG reflect climatic changes, whereas variations between the SEGs are related to sea level changes, small-scale lateral shifts or tectonic activity. Finally, the marine and terrestrial palynomorphs ratio $(\mathrm{m} / \mathrm{t})$ was presented. It provides information on sea level changes and is related to the $\mathrm{c} / \mathrm{l}$ indicator. The following relationships are observed: when the sea level rises during a transgressive phase, the Lowland SEGs and the $\mathrm{c} / \mathrm{l}$ indicator decreases whereas the value of the Upland SEG and the $\mathrm{m} / \mathrm{t}$ ratio are relatively high. In contrast, when the sea level falls in a regressive phase, the Lowland SEGs and the $\mathrm{c} / \mathrm{l}$ ratio increase and the $\mathrm{m} / \mathrm{t}$ ratio is low.

Although the outcomes of using the PPC and SEG models depend on the distance from land area, where miospores were produced, the general trends in climatic changes obtained at their basis coincide with those resulted from other factors like facies, clay minerals or isotope analyses (e.g., Abbink, 1998).

\section{APPLICATION OF THE PPC AND SEG MODELS TO MIOSPORE ASSEMBLAGES}

\section{OBSOLETA-PANTII ZONE}

Miospore spectra of the obsoleta-pantii zone were found in Lower Buntsanstein deposits of 13 boreholes concentrated in two regions - Western Poland and Holy Cross Mountains (Fig. 2; Appendix 1). The PPC model shows that (except in the Holy Cross Mts.) they are dominated by taeniate pollen of $M$ group (Protohaploxypinus, Striatoabietites and Lunatisporites), which represent xerophytic conifers, reaching even $>70 \%$ in some samples (Figs.12-14; Appendix 2). These are accompanied by hygrophytic and intermediate elements: fern (group B mainly Cyclotriletes) and lycopsid spores (group D - mainly Lundbladispora, and group G - Densoisporites) as well ascycadalean pollen (group $\mathrm{H}-$ Cycadopites and Gnetacaepollenites) reaching an average abundance of $20 \%$. In assemblages from the Holy Cross Mts. (except in the Jaworzna IG 1 borehole, Fig. 15 ) the dominance of hygrophytic elements of groups $D$ and $B$ is evident. Densoisporites spores (group G) and cycadalean pollen (group $\mathrm{H}$ ) are relatively abundant.

Applying the SEG model (Figs. 12-14; Appendix 2) evidences a marked dominance of the Upland SEG in W and NE Poland, and of the Lowland and River SEGs in the Holy Cross Mts (Fig. 15; Appendix 2). Coastal SEG is generally low and shows the $\mathrm{c} / \mathrm{l}$ ratio in average of $<1$. Only in few samples, the 


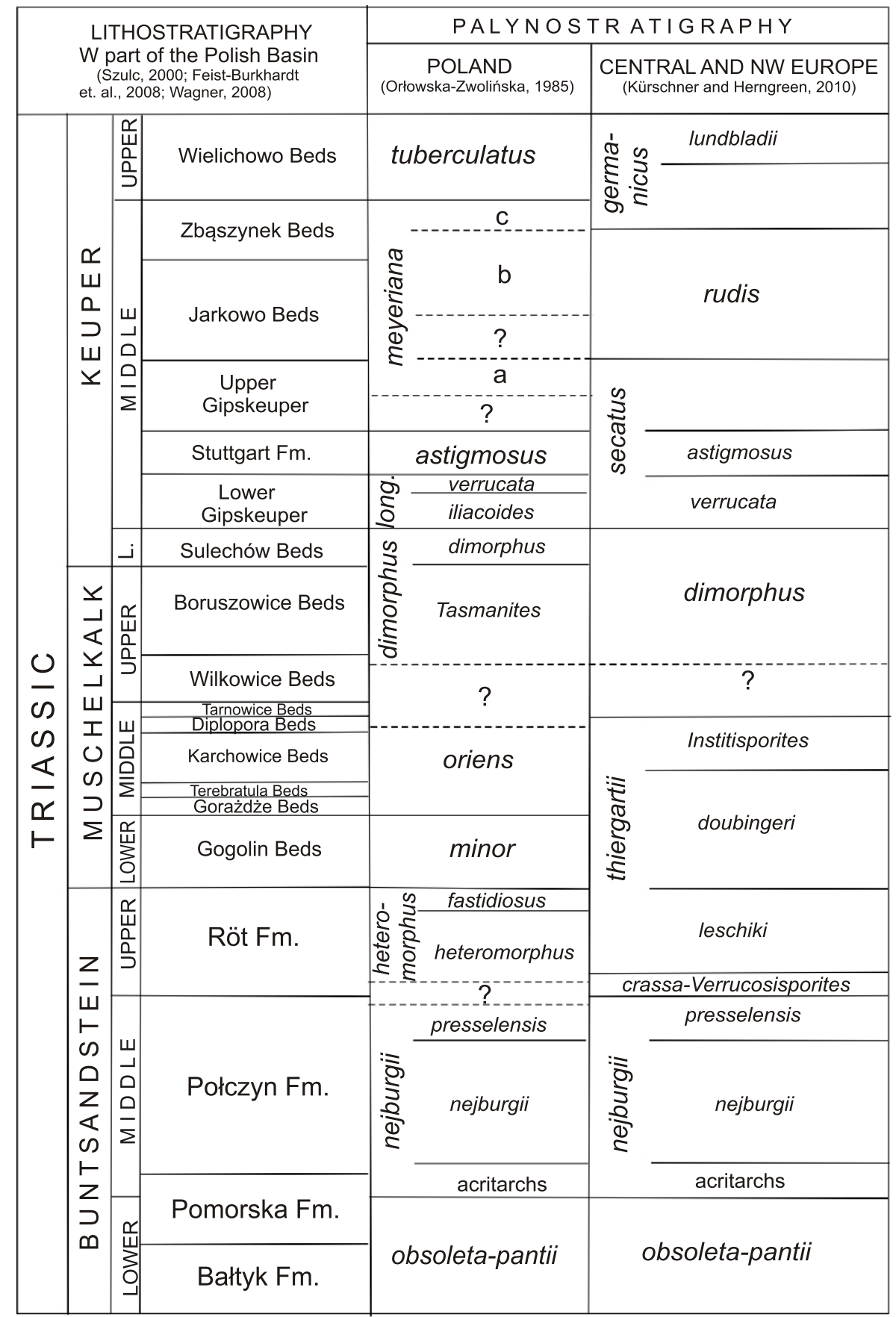

Fm. - formation, L. - lower, long. - longdonensis

Fig. 11. Comparison of the Triassic palynological zonation applied in Poland with that of Central and Northwestern Europe

Coastal SEG exceeds $20 \%$. Analysing in detail the composition of lowland flora, merely cycadalean pollen indicate "drier" climate conditions (Abbink, 1998; Abbink et al., 2004a, b). As they are a quantitatively important component of most miospore spectra, the w/d ratio is generally low - in average of $<2$ (Figs. 12-15; Appendix 2). This "drier" climate is confirmed also by the high amount of taeniate pollen in the spectra (see Meyen, 1987). In addition, Cycadopites pollen are suggested indicators of a "warmer" climate (Abbink, 1998; Abbink et al., 2004a, b). The low m/t ratio (0-0.5) evidences a weak Early Triassic transgressive impulse in the Polish Basin.
The following picture of Early Triassic plant communities appears from the sporomorph assemblages: bushy conifers have grown on dry uplands whereas lycopsids, ferns and mosses concentrated in the moist to wet inland floodplain and river banks. Cycads and lycopsids occupied seaside and inland like/playa coasts. These former could be an equivalent of the present mangrove communities (see Visscher et al., 1993). Both dry and wet areas with lower or higher salinity were overgrown by the pioneer lycopsid Pleuromeia. 
Attribution of the miospore genera to the SEGs

\begin{tabular}{|c|c|}
\hline SEG & Sporomorph genera \\
\hline Upland & $\begin{array}{c}\text { Accinctisporites, Alisporites, Angustisulcites, Brachysaccus, Cedripites, Ellipsovelatisporites, Enzonalasporites, } \\
\text { Heliosaccus, Infernopollenites, Klausipollenites, Kugelina, Labiisporites, Lunatisporites, Microcachryidites, } \\
\text { Minutosaccus, Ovalipollis, Parillinites, Partitisporites, Platysaccus, Praecirculina, Protohaploxypinus, Rhaetipollis, } \\
\text { Striatoabietites, Triadispora, Tsugaepollenites, Voltziacaesporites }\end{array}$ \\
\hline $\begin{array}{l}\text { Lowland and } \\
\text { River }\end{array}$ & $\begin{array}{c}\text { Acanthotriletes, Anapiculatisporites, Apiculatisporis, Aulisporites, Baculatisporites, Calamospora, } \\
\text { Camarozonosporites, Carnisporites, Chasmatosporites, Concavisporites, Conbaculatisporites, } \\
\text { Concentricisporites, Cycadopites, Cyclotriletes, Cycloverrutriletes, Deltoidospora, Dictyophyllidites, } \\
\text { Echinitosporites, Endosporites, Equisetumsporites, Eucommiidites, Gleicheniidites, Heliosporites, } \\
\text { Keuperisporites, Leschikisporis, Lycopodiacidites, Lycopodiumsporites, Marattisporites, Monosulcites, } \\
\text { Nevesisporites, Osmundacidites, Palaeospongisporis, Perinopollenites, Perotriletes, Porcellispora, } \\
\text { Punctatisporites, Riccisporites, Todisporites, Toroisporis, Trachysporites, Sphagnumsporites, Uvaesporites, } \\
\text { Verrucosissporites, Vitriesporites, Zebrasporites }\end{array}$ \\
\hline Coastal & $\begin{array}{l}\text { Aratrisporites, ? Cerebropolenites, Classopollis, Densoisporites, Densosporites, Duplicisporites, } \\
\text { Granuloperculatipollis, Illinites, Kraeuselisporites, Lundbladispora, Podosporites, Protodiploxypinus }\end{array}$ \\
\hline Not attributed & Camerosporites, Cerebropollenites, Polypodiumsporites, Sphaeripollenites \\
\hline
\end{tabular}

\section{NEJBURGI/ ZONE}

Spore-pollen spectra of the nejburgii zone were found in Middle Buntsandstein deposits of 16 boreholes and one outcrop (Fig. 3; Appendix 1). The PPC model shows that they are more differentiated than in the obsoleta-pantii zone.The assemblage of the nejburgii and acritarchs subzone from the Gorzów Wielkopolski IG 1 borehole consists almost exclusively of Sphaeripollenites pollen (intermediate element not attributed to any SEG) and acritarchs (Fig. 16). Fern spores (group B Cylotriletes) represent hygrophytic elements, and spores of Densoisporites nejburgii (Schulz) produced the by lycopsid Pleuromeia rossica Neuburg (Yaroshenko, 1975; Orłowska-Zwolińska, 1979) - intermediate forms (group G). In the Opoczno PIG 2 borehole, the assemblage of this subzone is strongly dominated by intermediate elements Densoisporites nejburgii (group G) and cycadalean pollen (group $\mathrm{H}$ ). The ratio of the xero- and hygrophytic elements is similar to that in the oboleta-pantii zone. Lycopsid spores of Endosporites genus (group D) and fern spores of Cyclotriletes (group C) are the main hygrophytic elements. Conifer pollen of Angustisulcites (group O) and Klausipollenites (P group) prevail among xerophytic forms (Fig. 17).

The SEG model evidences a marked dominance of Lowland SEG. The low value of the $w / d$ ratio indicates a dry climate. The presence of acritarchs ( $\mathrm{m} / \mathrm{t}$ ratio $0.5-5)$ and the low c/l indicator (Figs. 16 and 17; Appendix 3) are related to the Early Olenekian transgression in the Polish Basin.

Though a quantitative increase of the hygrophytic elements - mainly lycopsid spores Endosporites and Lundbladispora (group D) as well as fern spores Cyclotriletes and Punctatisporites (group B) - the Densoisporites spores (group $\mathrm{G}$ ) remained dominant (on average $>40 \%$; in some samples even $80 \%$ ) in the assemblages of the nejburgii subzone (Figs. 12, 14 and 16-19; Appendix 3). Xerophytic elements are dominated by conifer/gingko pollen Protohaploxypinus, conifer pollen Lunatisporites (M group) and Platysaccus (group O).

The SEG model is dominated by the Lowland and River SEG as well as Coastal SEG (Figs.12, 14, 16, 17 and 19; Appendix 3). The $\mathrm{c} / \mathrm{l}$ ratio, higher than in older assemblages, evidences the Middle Olenekian regression. The w/d ratio is also higher than in older spectra and varies from 2 to 26 (Figs. 12, 14 and 16-19; Appendix 3$)$, reflecting a gradual humidification of climate.

In spite of the further increase of the number of hygrophytic elements (group B - mainly fern spores Cycloverrutriletes, group D - lycopsid spores Lundbladispora, and group O caytonialean pollen Vitreisporites), group D still dominates in the assemblages of the presselensis subzone (Figs. 12 and 16F; Appendix 3). Conifer taeniate pollen (M group) and vesicate pollen (group P) are the main xeromorphic forms.

The high value of the w/d indicator (from several to 50 ) is a characteristic feature of analysed assemblages (Figs. 12 and 16-21; Appendix 3) and marks the humide phase in the Late Olenekian.

The SEG model shows a marked dominance of Coastal SEG with exception of the Holy Cross Mts., where the Lowland and River SEG prevails. A relatively high c/l ratio, with a maximum value of 25 in some samples, evidences the Late Olenekian regressive trend in the Polish Basin.

Distribution of the plants in the Olenekian was similar to that in the Induan: lycopsids - mainly Pleuromeias - and ferns occupied moist to wet inland floodplains as well as marine coastal and deltaic environments (Mader, 1990a; Visscher et al., 1993; Abbink, 1998; Grauvogel-Stamm, 1999; Abbink et al., 2004a, b). Caytoniales, which produced Vitreisporites pollen (Balme, 1995), were associated with a fluvial environment, whereas other gingkoales and conifers overgrew dry uplands.

Compared to the Induan, the Olenekian miospore assemblages show a higher number and diversity of specimens. A trend of declining dominance of lycopods and rising prevalence of woody gymnosperms is observed. This phenomenon has a global character and reflects the recovery of diverse plant ecosystems after the end-Permian biotic crisis (e.g., Looy et al., 1999; Galfetii et al., 2007; Lindström and McLoughlin, 2007; Hermann et al., 2010, 2011a, b).

\section{HETEROMORPHUS ZONE}

The material comes from Upper Buntsandstein (Röt) deposits of 21 boreholes and one outcrop (Fig. 4; Appendix 1).

The PPC model shows that miospore assemblages of this zone are strongly dominated by xerophytic elements - conifer pollen with prevalent trilete pollen of Voltziacaesporites and Angustisulcites (group O), in average of $20-30 \%$ (Figs. 12, 16-18, 22 and 23; Appendix 4). Vesicate pollen Microcachryidites and Klausipollenites (group P), taeniate pollen Protohaploxypinus and Striatoabietites (group M) as well as Triadispora (group N) occur abundantly. Illinites chitonoides Klaus (al. Succinctisporites grandior Leschik sensu Mädler) 


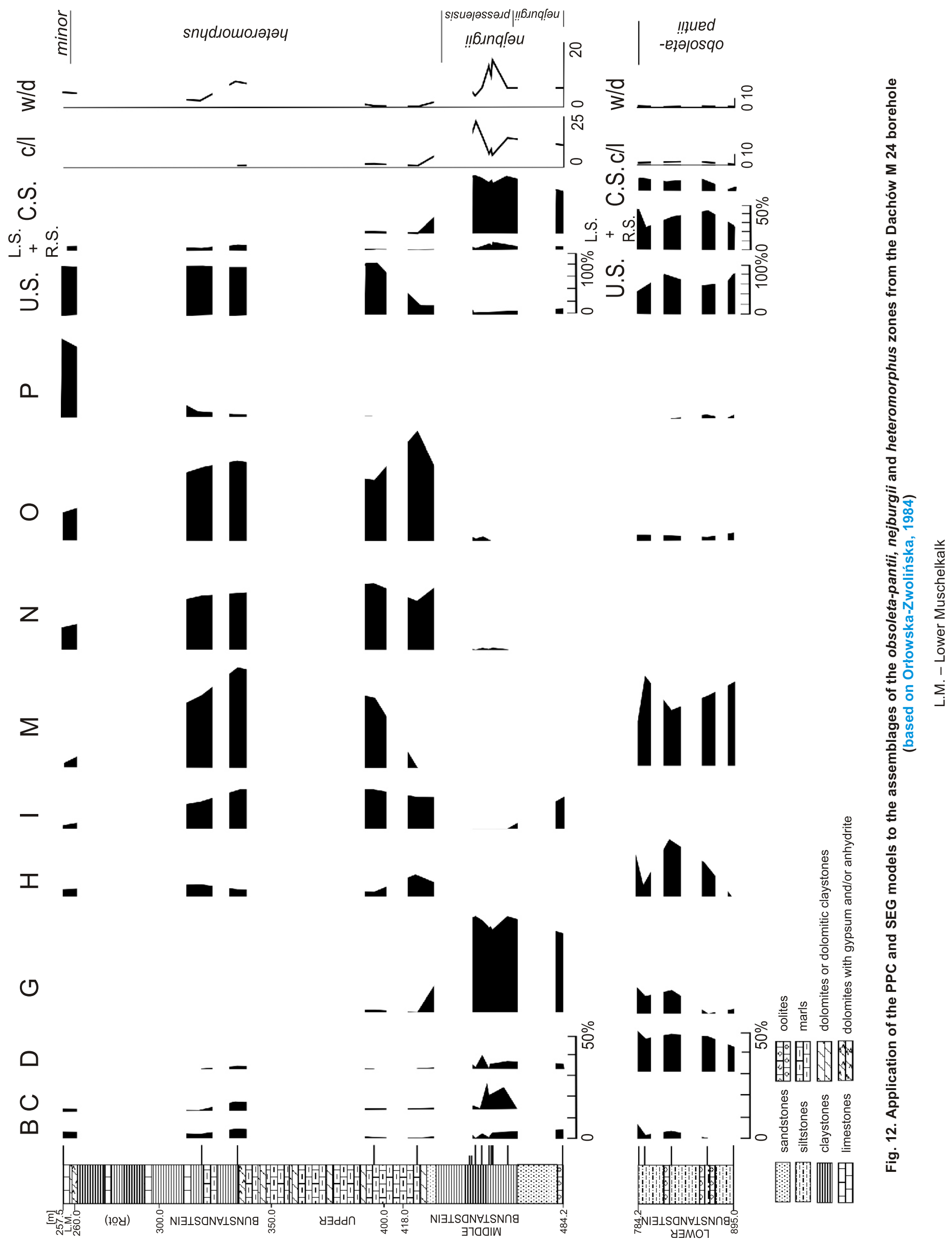



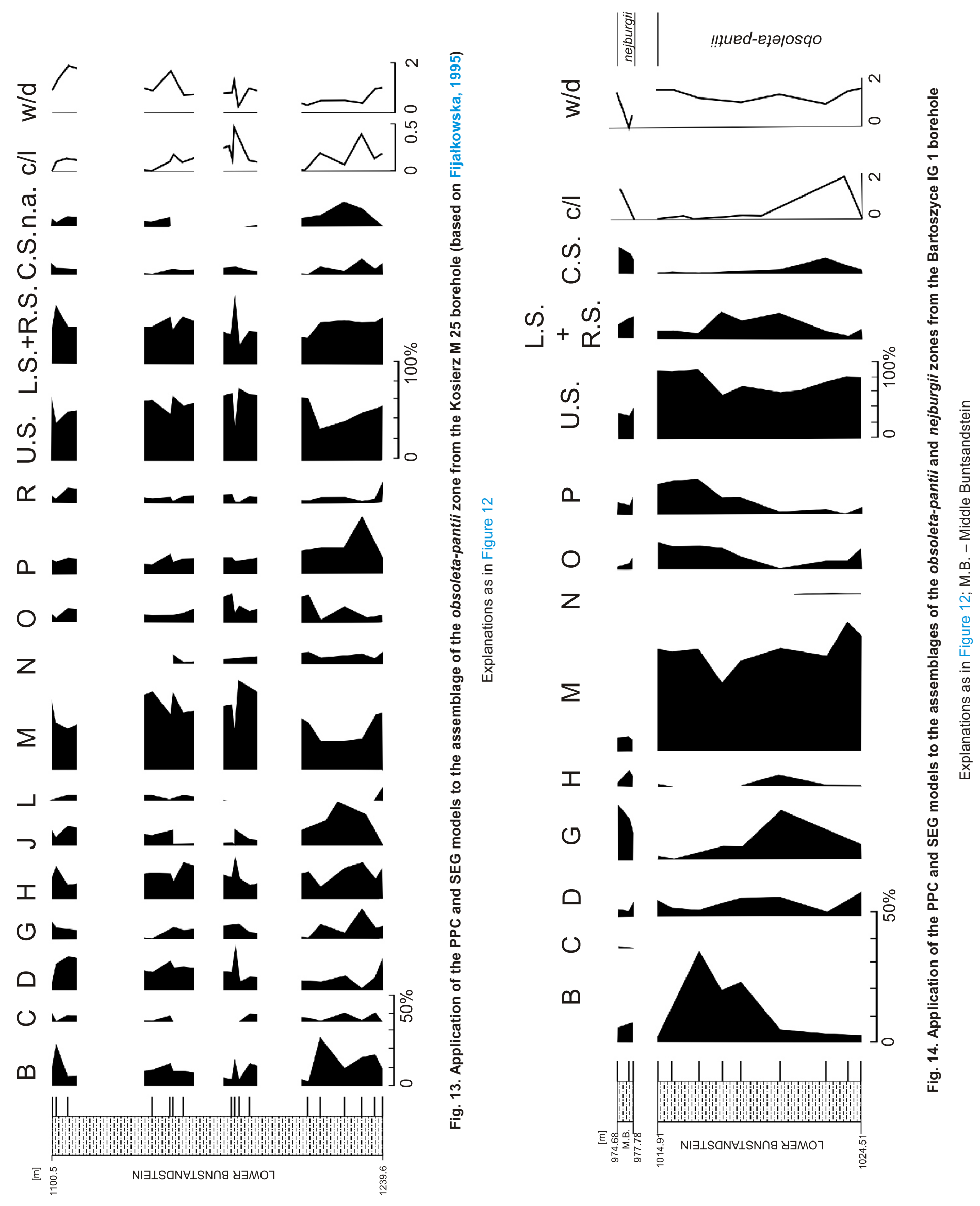


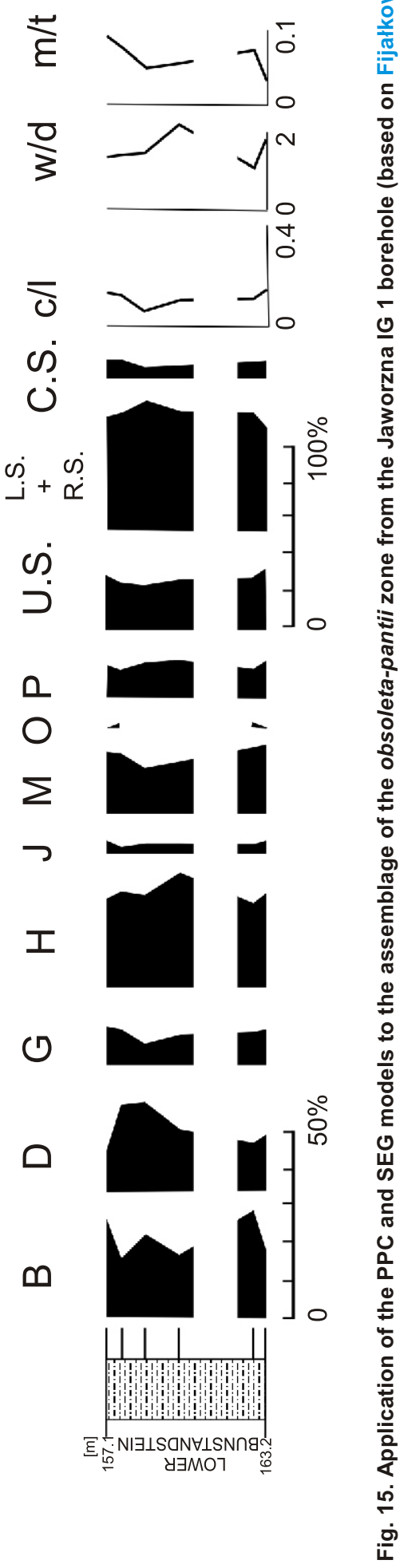

(group I), produced by the ruderal herbaceous conifer Aethophyllum stipulare (Brongiart) (Grauvogel-Stamm, 1978; Rothwell et al., 2000), is a characteristic element of the Early Anisian spectra. Fern spores Cyclotriletes (group B) and Verrucosisporites (group C), cycadalean pollen (group G) and lycopsid spores Aratrisporites (group E) prevail among the hygromorphic components.

The w/d indicator curve has a marked "arid" pick in the assemblages representing the upper part of the heteromorphus zone, distinguished as the fastidiosus subzone (Figs. 18, 22 and 23), which correspods to the arid climate in Early Anisian.

The SEG model shows a remarkable dominance of the Upland SEG (in average of $>80 \%$ ) (Figs. 12, 16-18, 22 and 23; Appendix 4) consisting most exclusively of conifers. The Lowland SEG is relatively poor and represented by rare lycopsids, ferns and horsetails. The low c/l ratio - in average of $<1$ (Figs. 16 and 18; Appendix 4) and the presence of acritarchs mark the Early Anisian transgression in the Polish Basin. Strong dominance of conifer pollen in the Early Anisian spectra evidences the next phase of forestation during the Triassic (e.g., Kürschner and Herngreen, 2010).Taxonomically diverse conifer forests and bushfields occupied not only dry uplands but also marine/lagoon coasts, where Aethophyllum stipulare formed reed-like belts (Grauvogel-Stamm, 1978; Mader, 1990a; Visscher et al., 1993). This plant was an important element of wetland communities during the Middle Triassic (Brugman et al., 1994; Rothwell et al., 2000).

\section{MINOR ZONE}

Miospore assemblages of the minor zone were found in Lower Muschelkalk deposits of 10 boreholes (Fig. 5; Appendix 1). In majority of the studied samples they are strongly dominated by xerophytic conifer pollen Microcachryidites (group P) with average abundance of $>20 \%$ (Figs. 12, 16 and 18; Appendix 5). Conifer pollen Angustisulcites (group O) and Triadispora (group N) occur less frequently. Lycopod spores Aratrisporites (E group), spores Perotriletes of unknown botanical affinity (group D), fern spores Cyclotriletes and horsetail spores Equisetumsporites (group B) represent the hygrophytic forms.

The SEG model shows that Upland SEG, composed most exclusively of conifers, prevails in all analysed samples (in average of $>80 \%$; Figs. 12, 16 and 18; Appendix 5) which could partly result from the distance to land areas. Only in few samples, a higher abundance of the Lowland and River SEG is observed (Appendix 5). The low c/l ratio results from transgression of the Muschelkalk sea documented by the presence of acritarchs (see $\mathrm{m} / \mathrm{t}$ indicator). A rise of the $\mathrm{w} / \mathrm{d}$ ratio is observed in relation to the heteromorphus zone, which is $>7$ in some samples and reflects wet climate conditions.

Distribution of palaeoflora was similar to that known from the Early Anisian. Visscher et al. (1993) suggested, based on the palynomorph spectra from Southern Germany, a recessive palaeoflora migration from coastal areas towards inland.

\section{ORIENS ZONE}

Assemblages of the oriens zone were found in Middle Muschelkalk deposits of nine boreholes (Appendices 1 and 6). They consist almost entirely of xerophytic elements that include conifer pollen Triadispora (group N), Microcachryidites (group P) and Angustisulcites (group O) (Figs. 24 and 25; Appendix 6). Dominance of Triadispora pollen is also observed in spectra from Southern Germany (Visscher et al., 1993; Kürschner and Herngreen, 2010). 


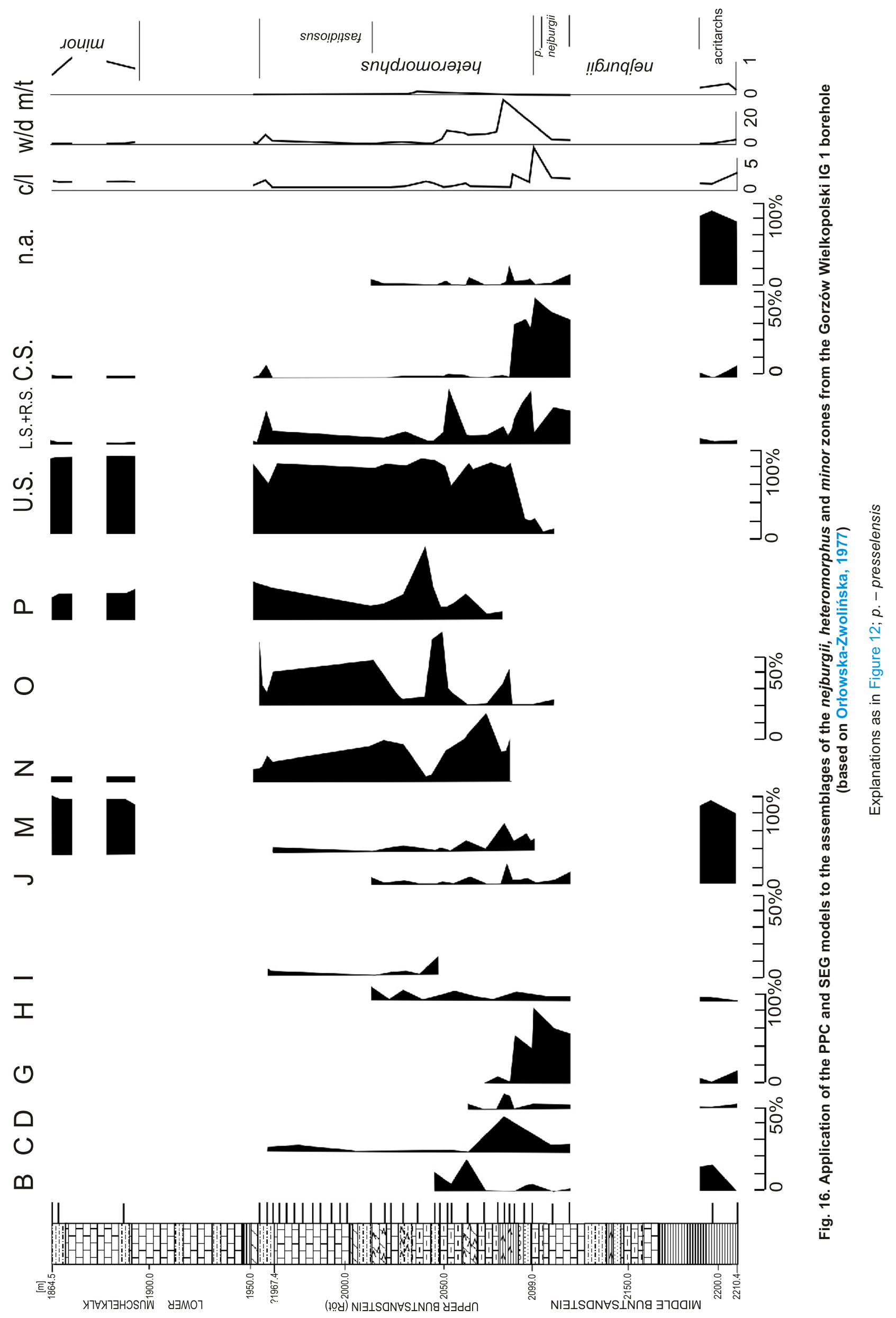




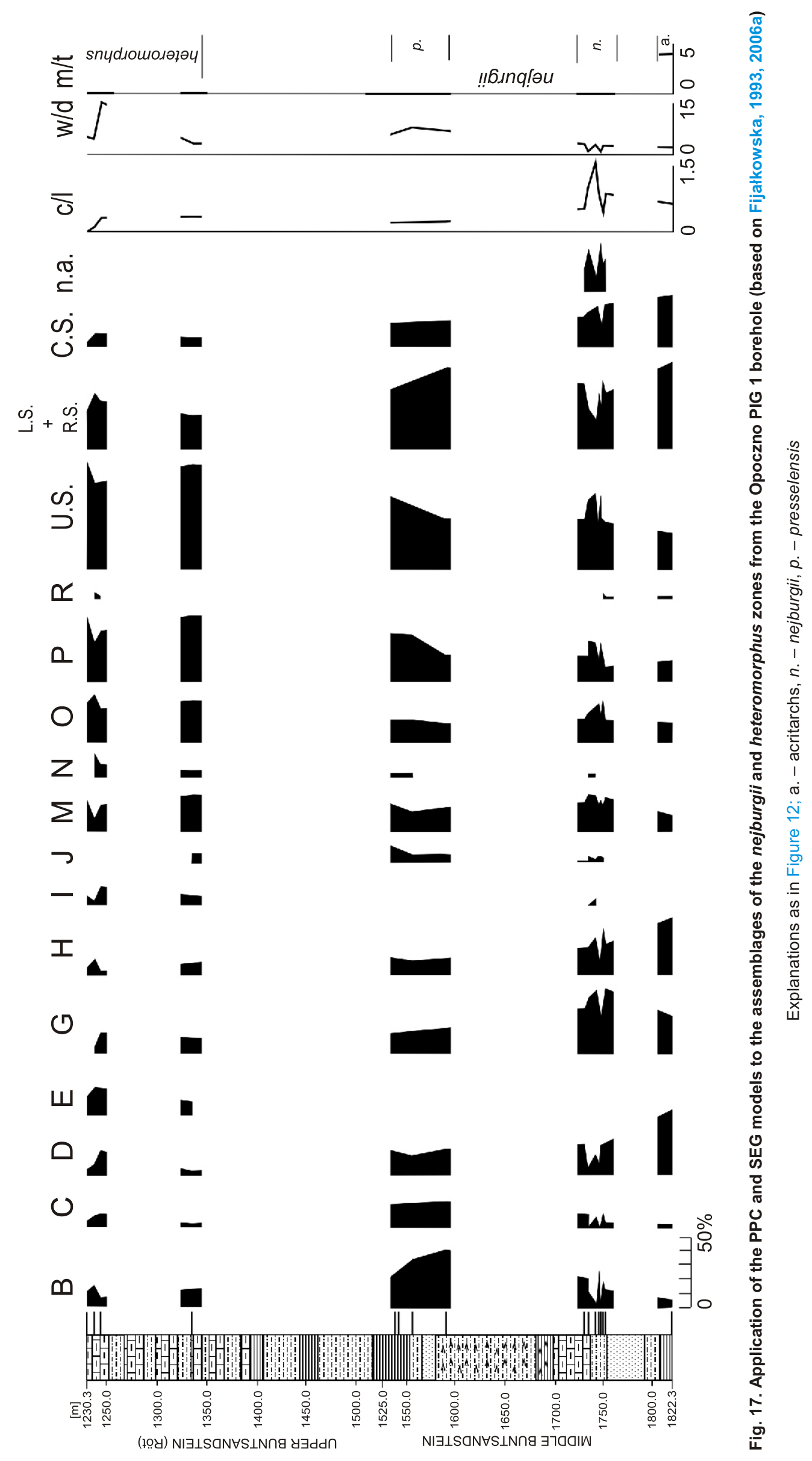




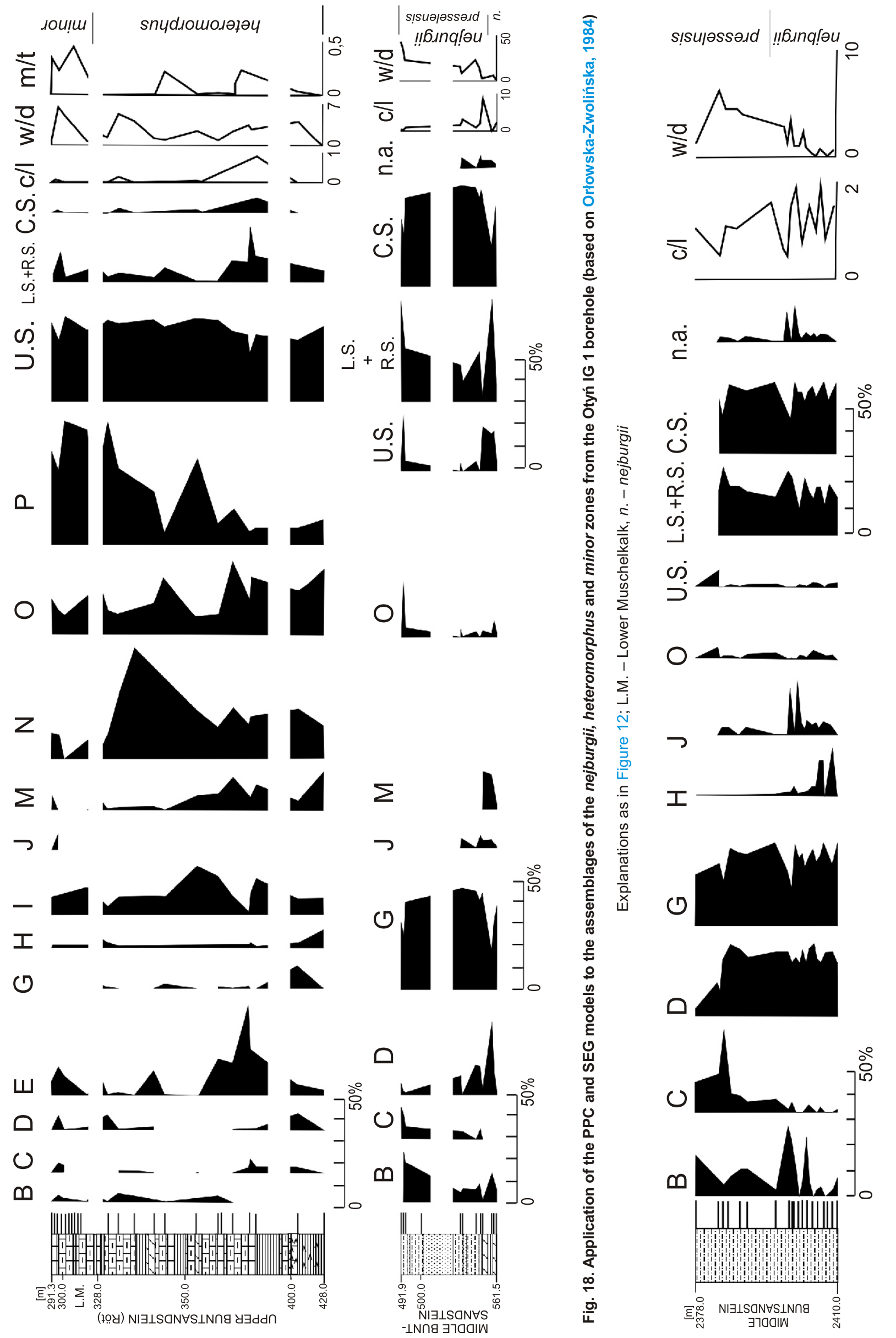



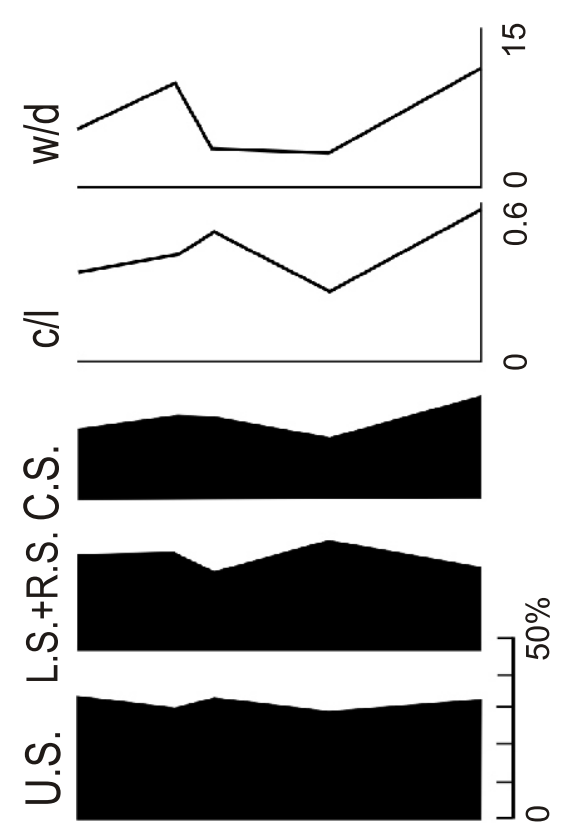

ฉ
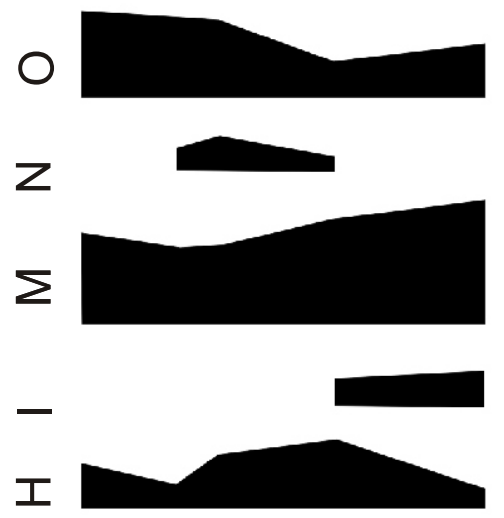

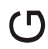
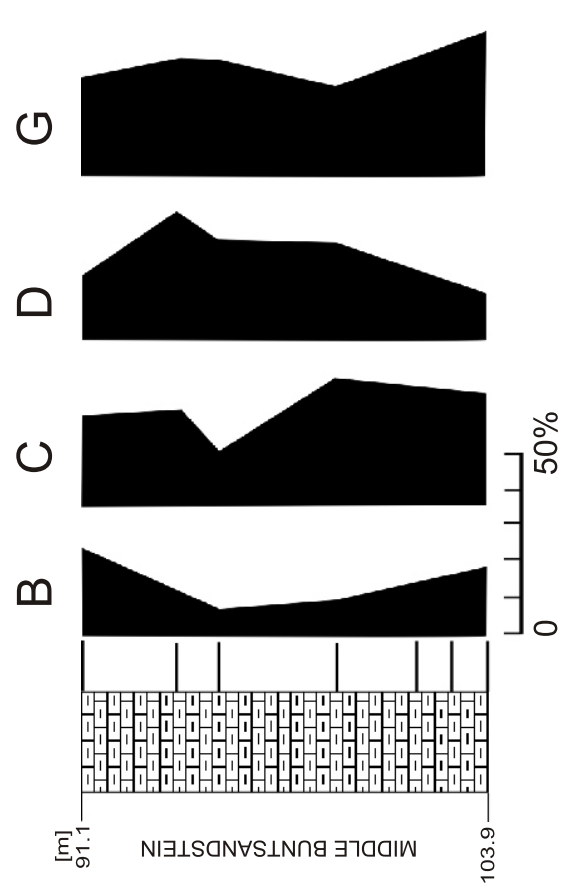

The very low w/d indicator - in average of $<1$ (Figs. 24 and 25; Appendix 6) marks dry climate conditions in the Late Anisian.

The Upland SEG shows the highest values among the Triassic miospore spectra, with an average of $90 \%$. The Coastal SEG is highly reduced, even to 0 in same samples, which implies a very low $\mathrm{c} / \mathrm{l}$ ratio related to the transgressive trend in the Polish Basin.

\section{DIMORPHUS ZONE}

TASMANITES SUBZONE

The material comes from Upper Muschelkalk deposits of seven boreholes (Appendices 1 and 7 ).

The PPC model evidences significant differences in the spectra from the lower part of the dimorphus zone Tasmanites subzone - between the individual regions of Poland. In general, the assemblages from NE Poland and the Nida Basin are dominated by xerophytic elements (P group), whereas those from eastern and western Poland as well as the Holy Cross Mts - by hygrophytic forms (groups E and B; Figs. 24-30; Appendix 7).

Conifer pollen Minutosaccus (al. Protodiploxypinus; group P), Triadispora (group N), Illinites (group I) and monosaccate pollen Heliosaccus (group R) are the main xerophytic elements. Taeniate pollen of Striatoabietites and Protohaploxypinus (group M) occur less frequently. Lycopsid spores Aratrisporites (group E), fern spores Todisporites (group $\mathrm{B}$ ) and Verrucosisporites (group C) prevail among hygrophytic forms.

The w/d ratio value is variable and relatively high: $30-70$ in $\mathrm{N}-\mathrm{NW}$ Poland and the Holy Cross Mts., 11-30 in E-NE Poland and the Nida Basin (Figs. 24-30; Appendix 7), indicating a wet climate in the Early Ladinian.

The SEG model shows a remarkable dominance of the Lowland and River SEG in western Poland and the Holy Cross Mts. (in average of $>65 \%$ ) and of the Upland SEG in NE Poland and the Nida Basin. The Coastal SEG varies from 4 to $17 \%$ and the $\mathrm{c} / \mathrm{l}$ ratio is $0.1-0.8$ (Figs. 24-30; Appendix 7). Low m/t ratio indicates a weak influence of the Early Ladinian transgression in the Polish Basin.

Conifers overgrown not only dry uplands but also occurred as pioneers in the xerophytic marine coastal palaeobiocenosis. An important component of these plant communities was Voltziales producing pollen Minutosaccus gracilis (Scheuring) Orłowska-Zwolińska and Podosporites amicus Scheuring (Visscher et al., 1993; Kürschner and Herngreen, 2010). Lycopsids and ferns represented wetter lowland floras.

DIMORPHUS SUBZONE

Miospore assemblages representing the upper part of the dimorphus zone - dimorphus subzone were found in the Sulechów Beds (Lettenkeuper) deposits from 18 boreholes (Fig. 6; Appendix 1). They are dominated by hygrophytic elements: equisetales spores Calamospora, fern spores Todisporites and Cyclotriletes (group B) (in average of $>30 \%$ ) and taxonomically diverse Aratrisporites spores (group E) (4-50\%) (Figs. 24, 25 and 28-32; Appendix 8). Conifer pollen Minutosaccus and Brachysaccus (group P) (10-40\%) are the main xerophytic components.

The w/d ratio varies widely from 0.5 to 58 , but is generally high (in average of $>20$ ) with a decreasing trend in the upper 

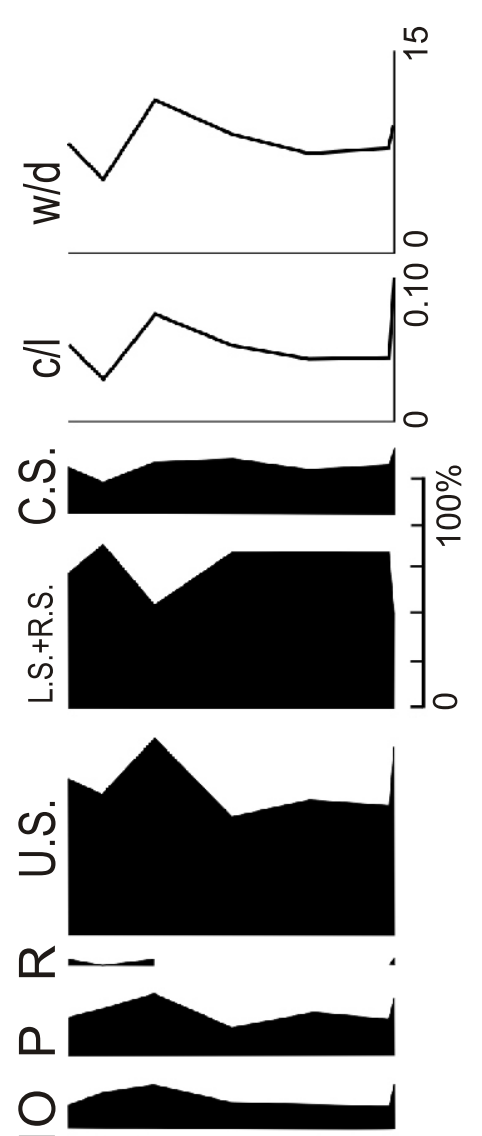

Z-
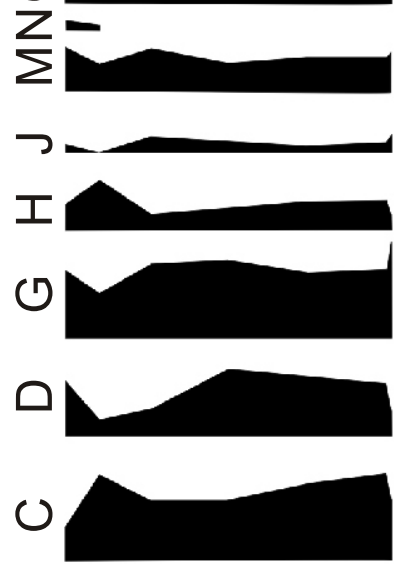

m

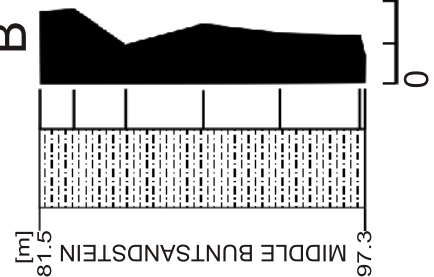

1:
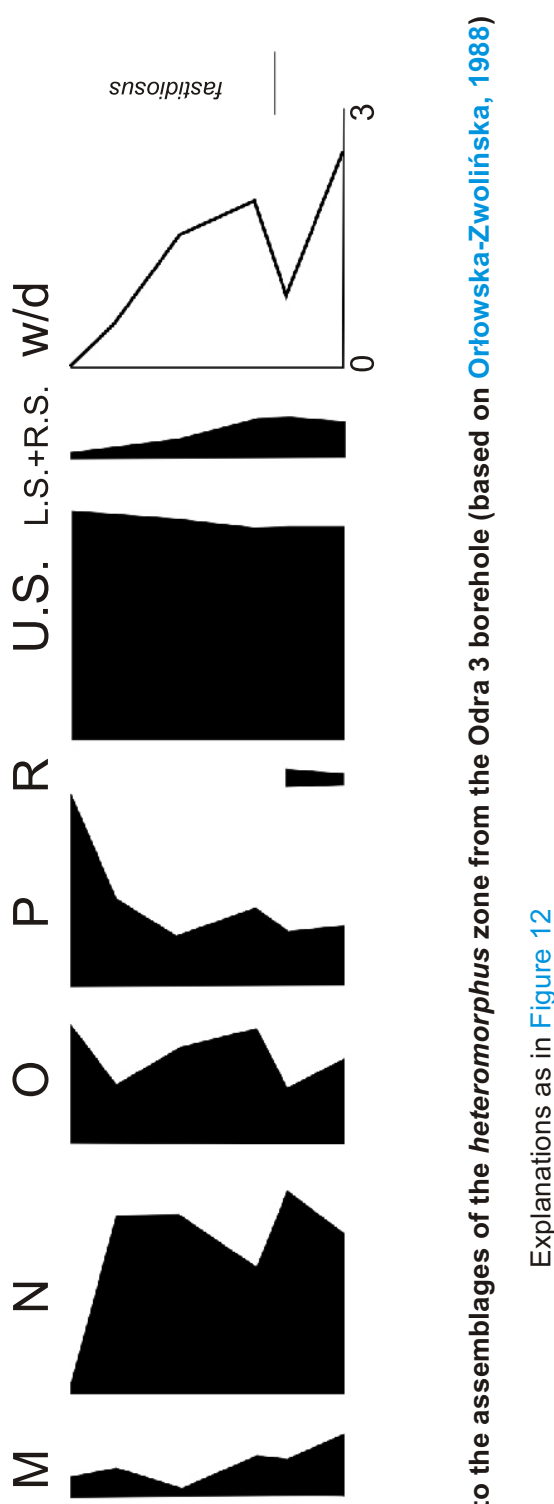

○

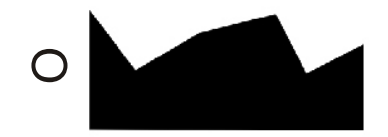

$\square$

0

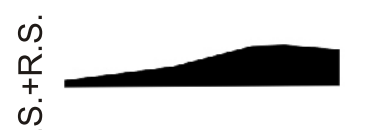

$\propto$ (1) ن.

$\frac{0}{3}$

snso!p!nsef |

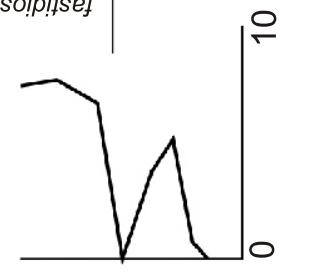

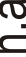

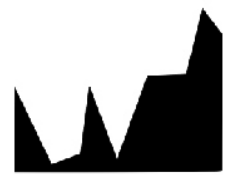

क

ij

峁

$\stackrel{\leftrightarrow}{-\infty}$

$\stackrel{\oplus}{\supset}$
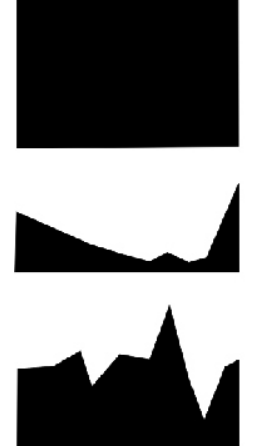

$Z$
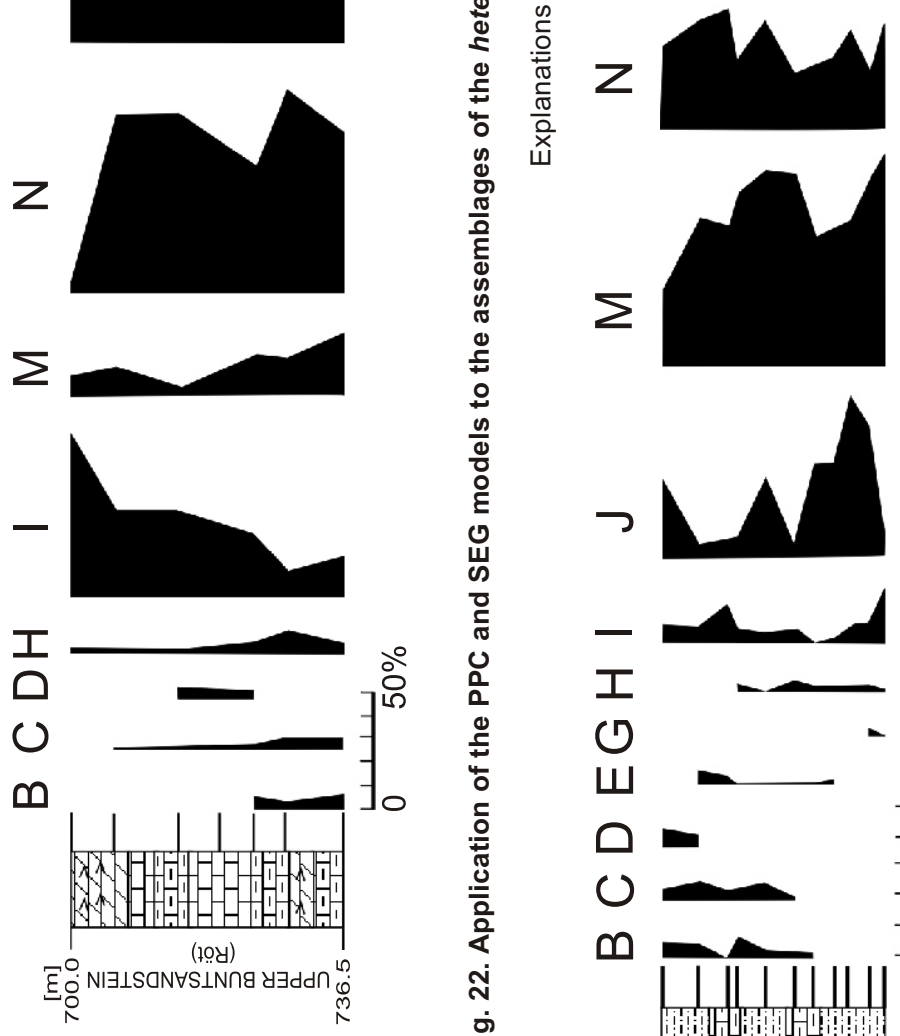

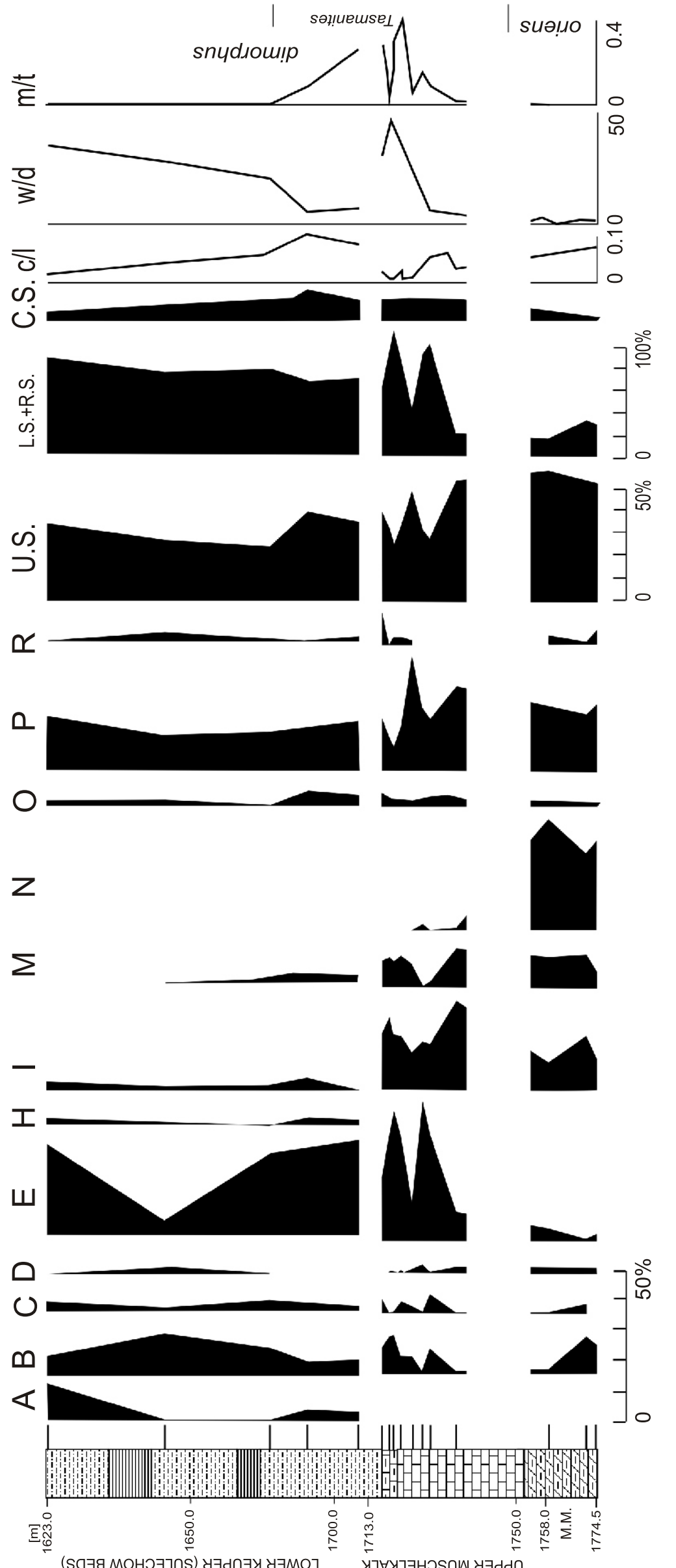

$\infty$
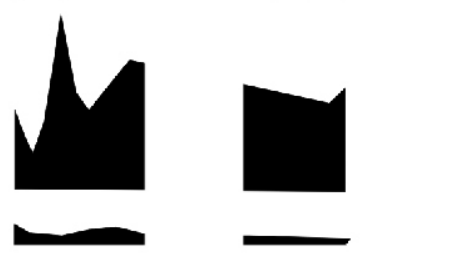

0

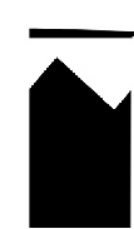

要 


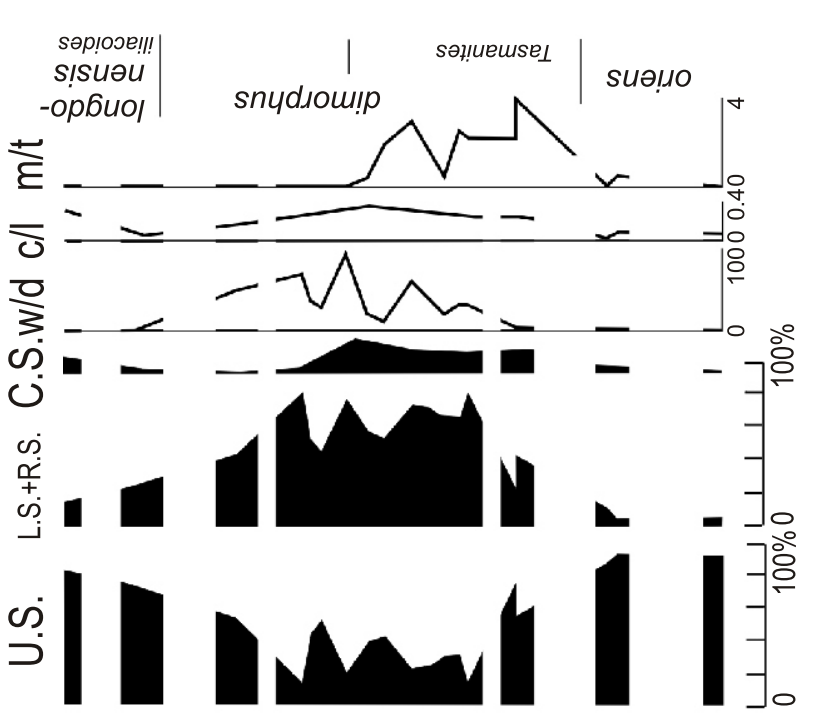

$\Upsilon \quad-1$

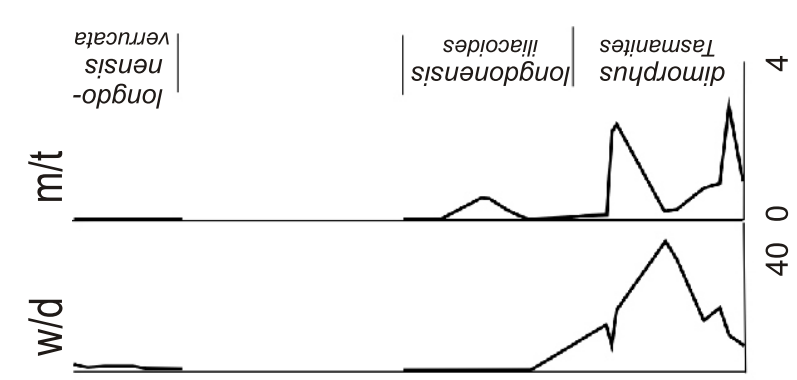

0
$z=-$
$\Sigma=-\infty$ צ11

$-=\ldots$.
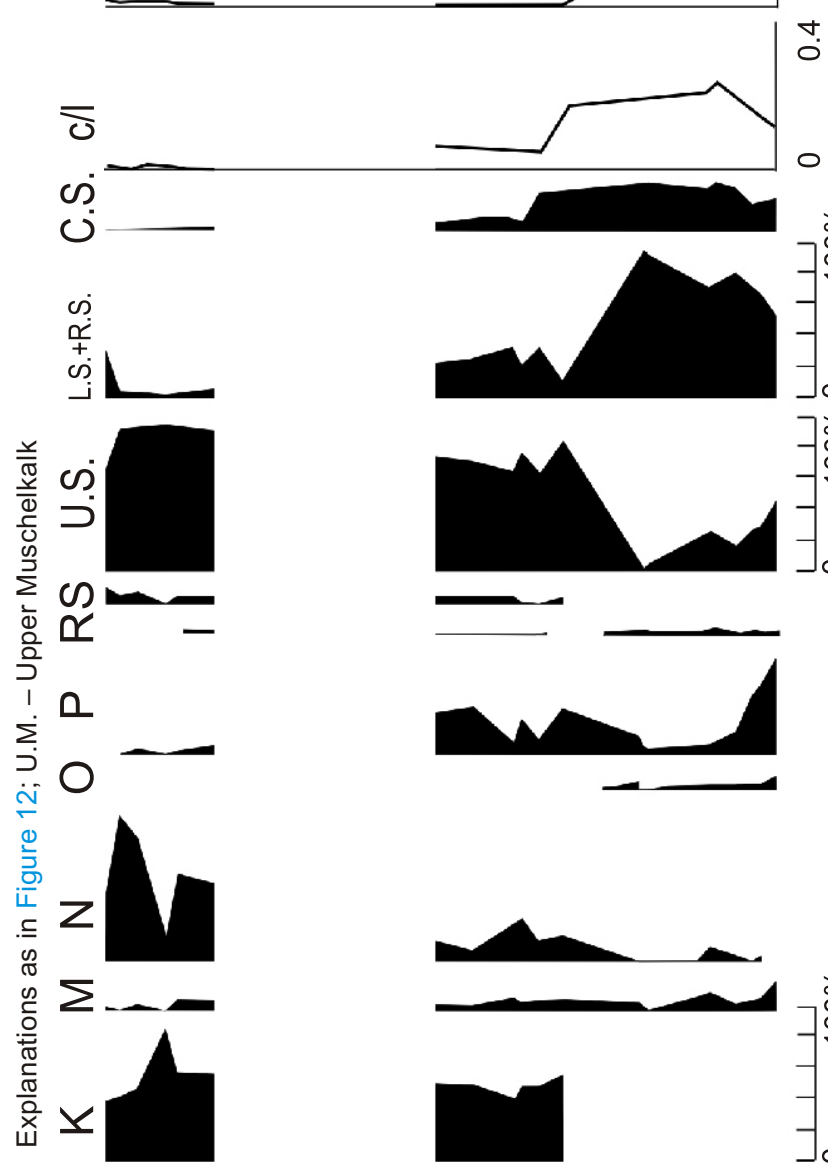

年

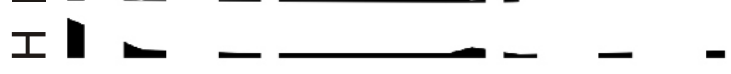

แ. 1

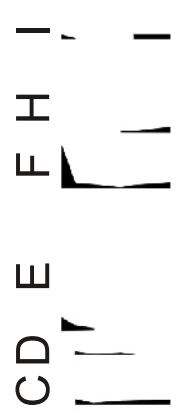

$\infty$ $\varangle=$
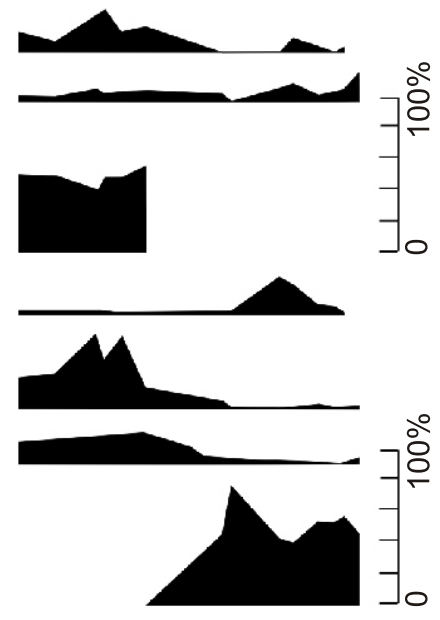

ט

$\mathbf{n}$
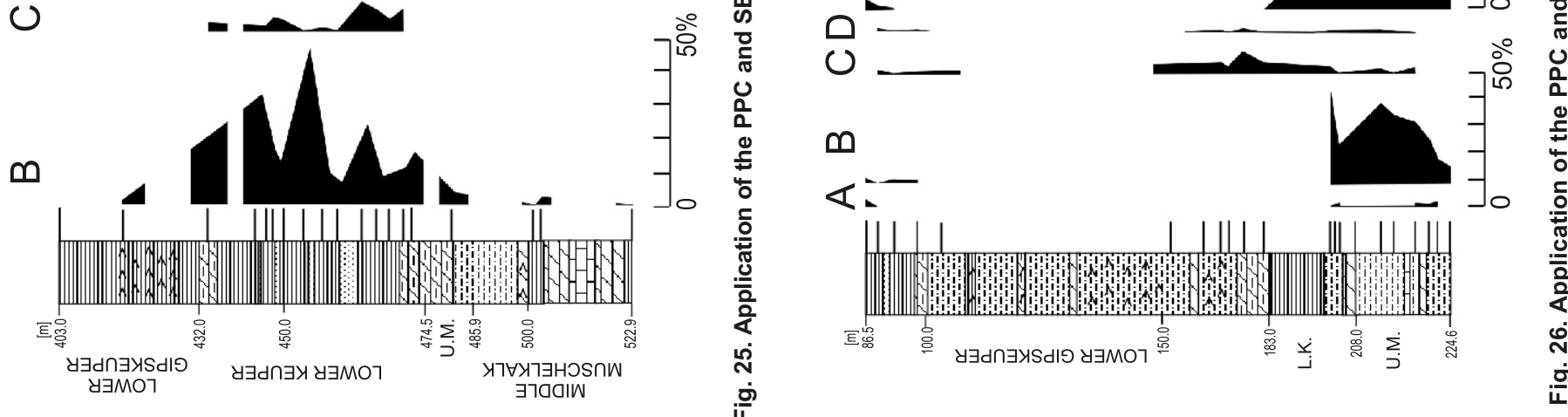

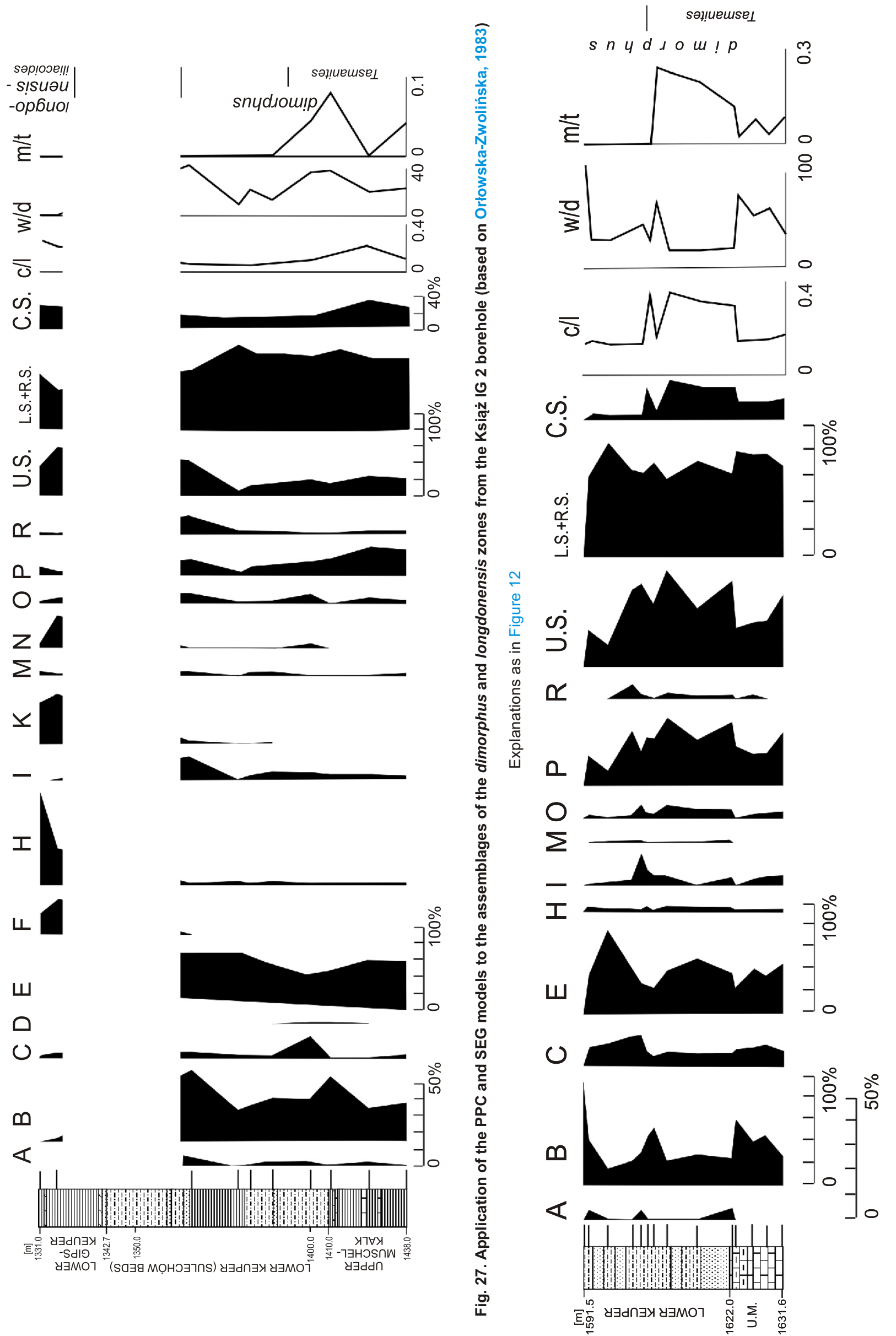

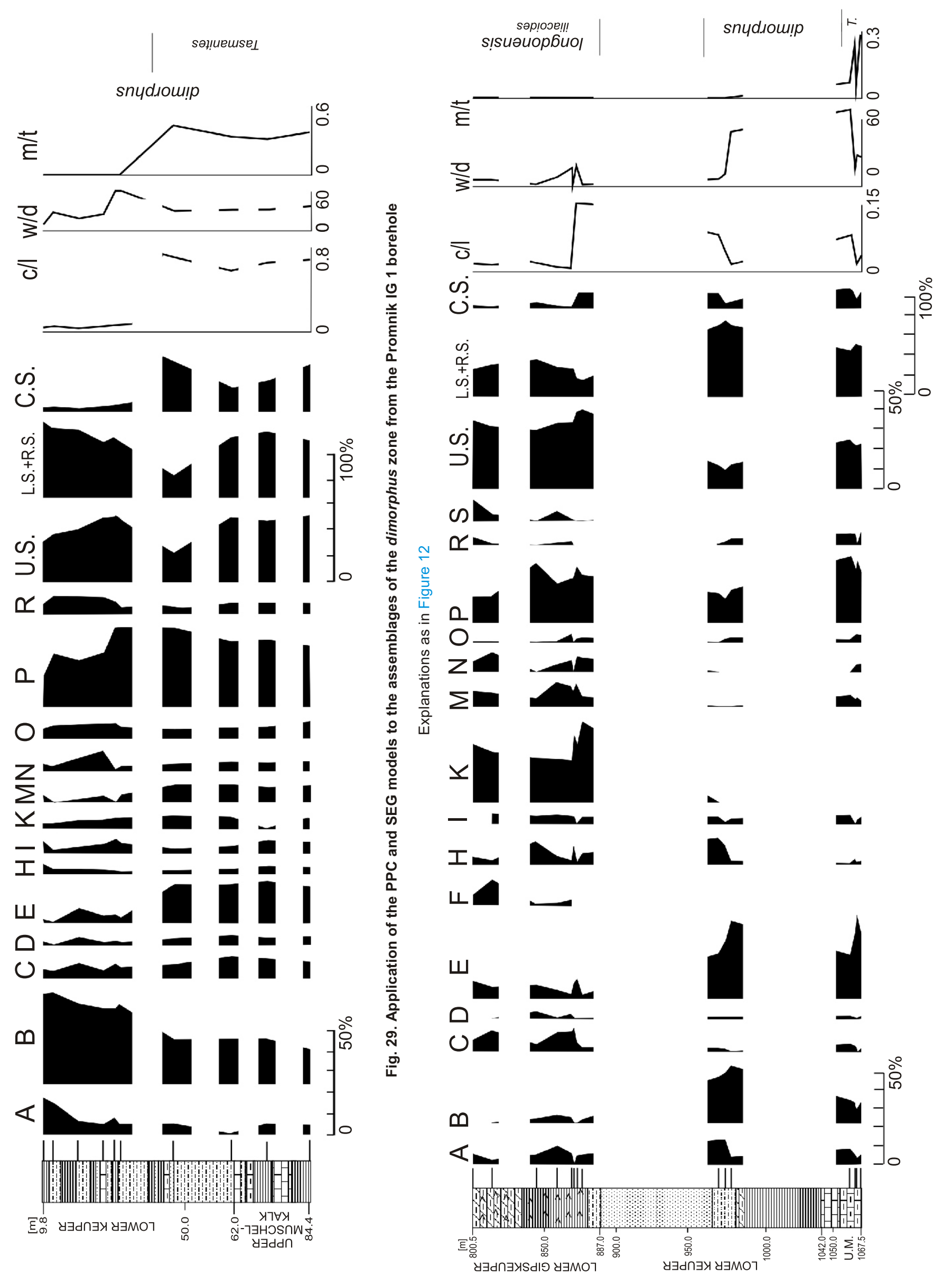

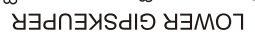




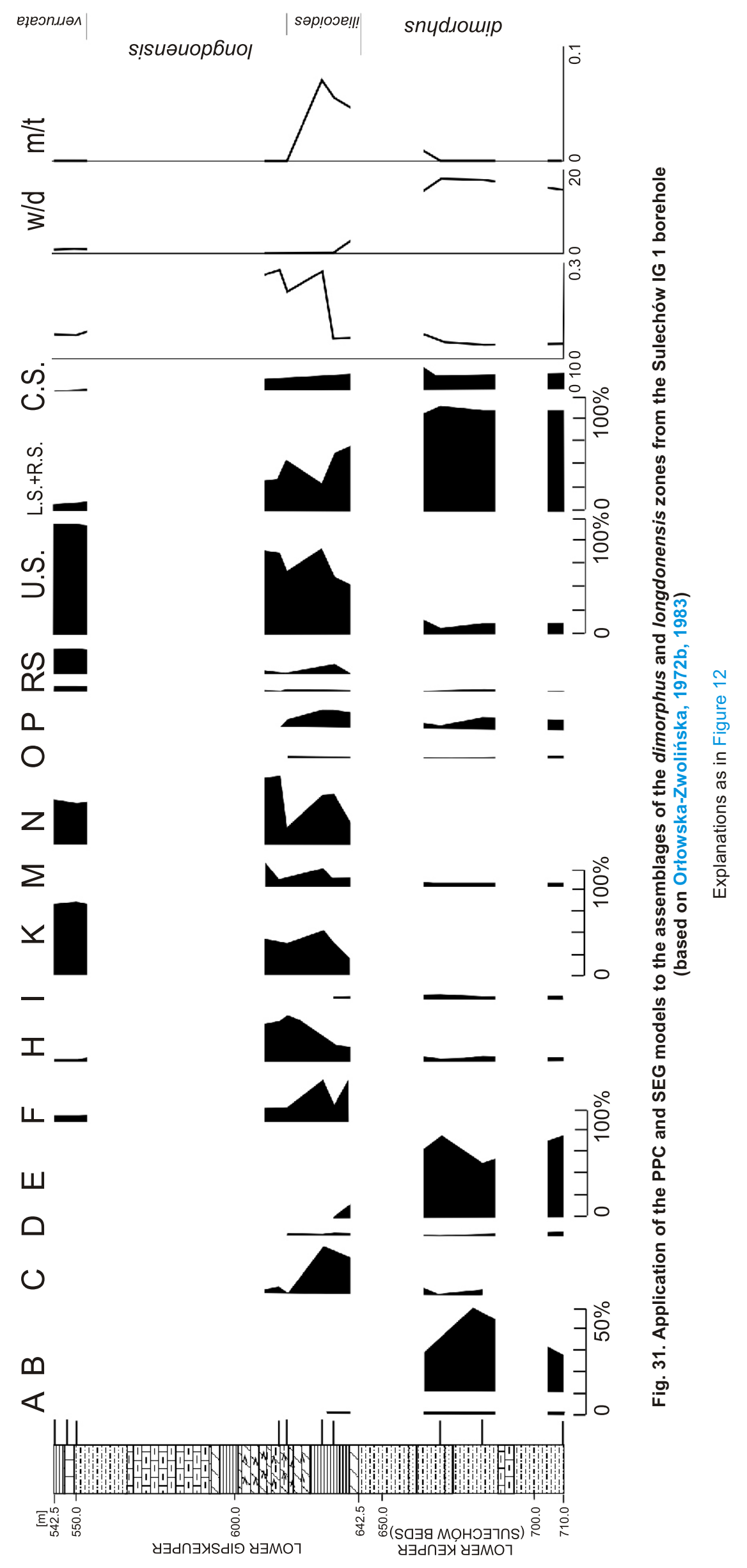




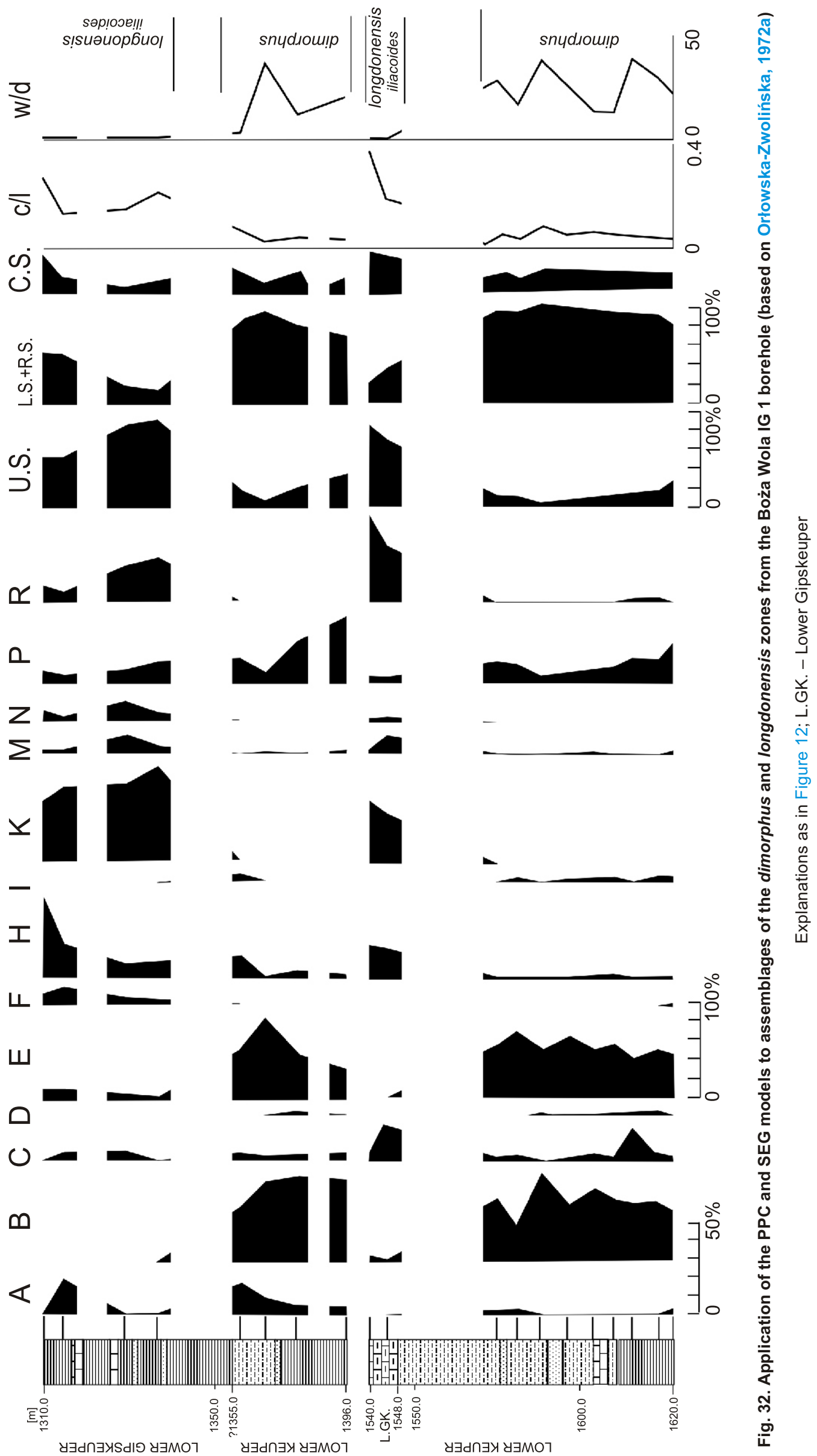



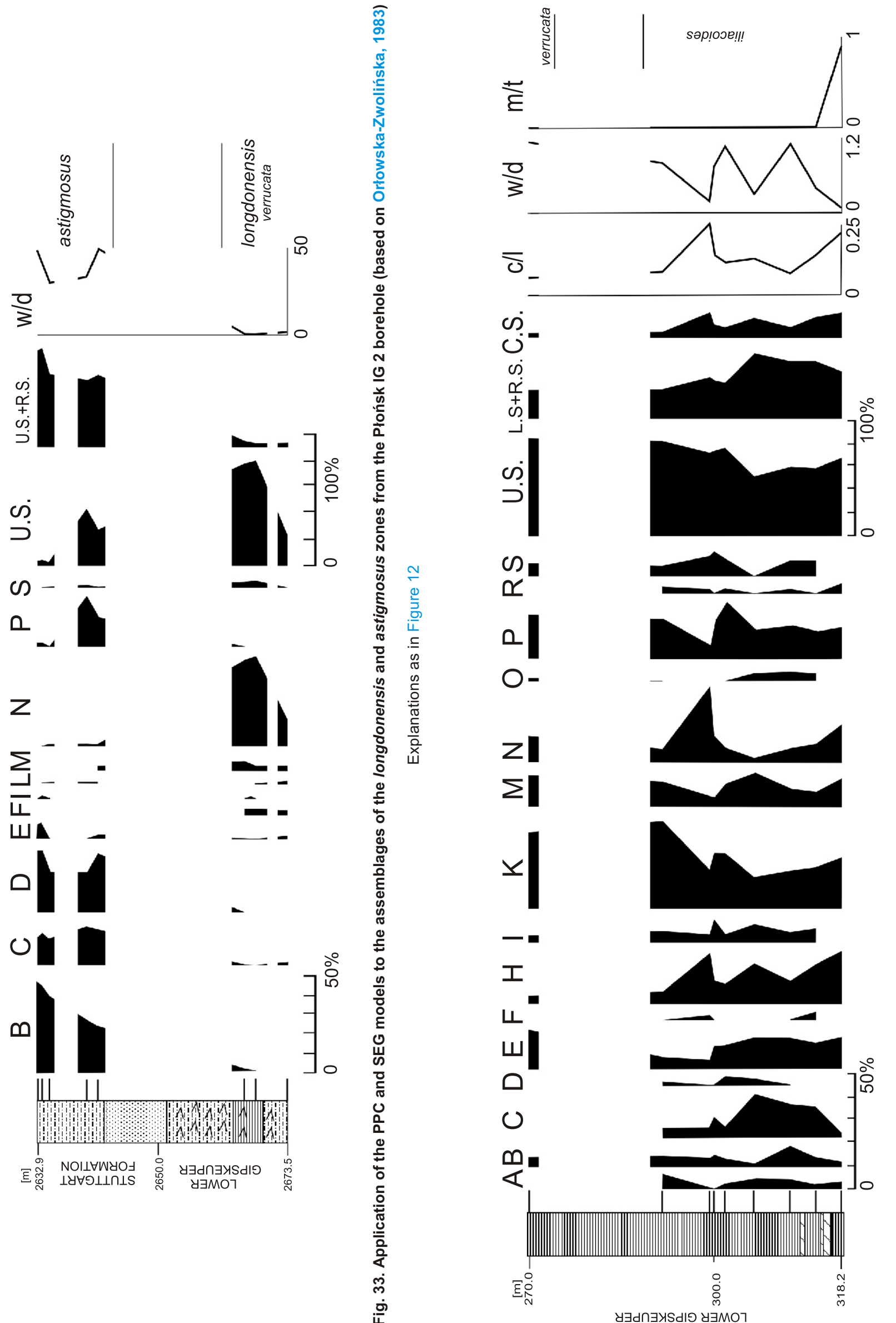

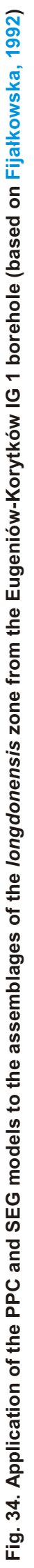

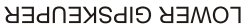




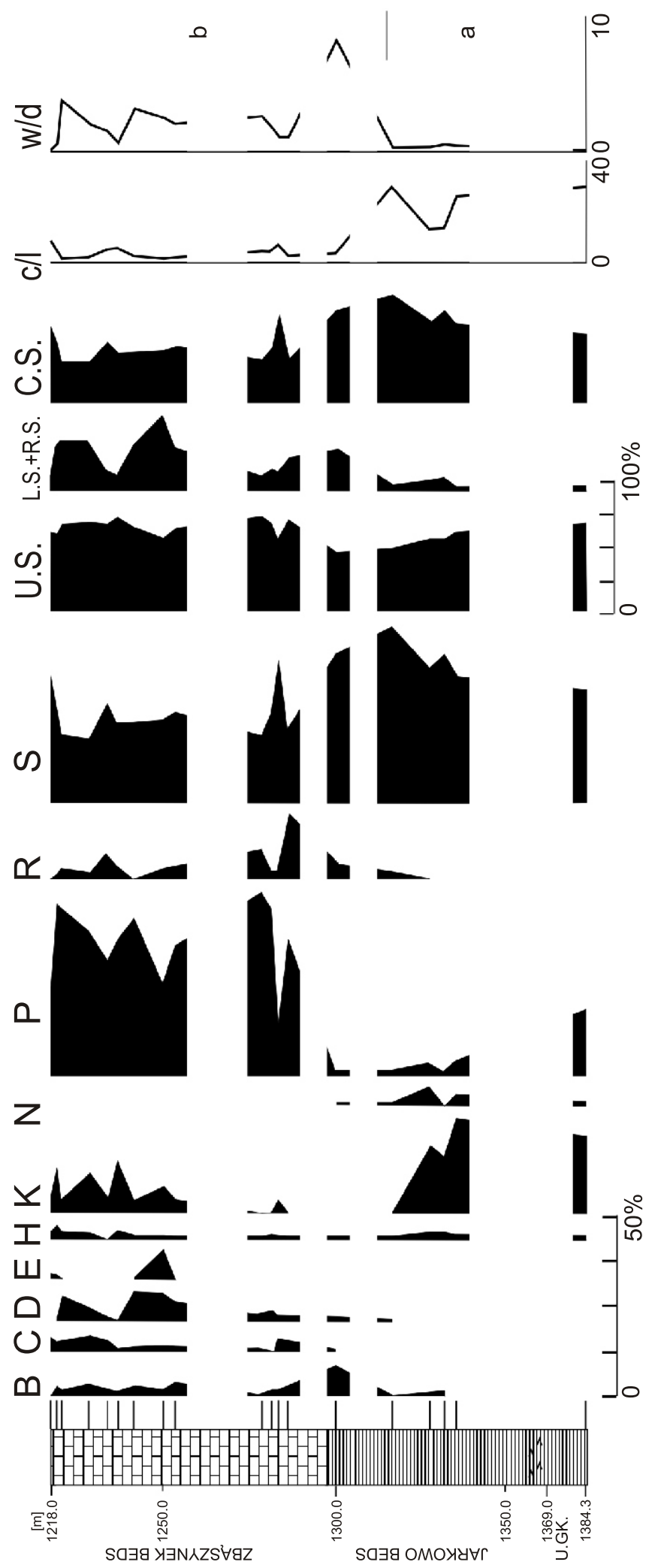

part of the zone (Figs. 24, 25 and 28-32; Appendix 8), suggesting a gradual aridification of the Late Ladinian climate.

Lowland and River SEG strongly dominates in the SEG model with a maximum of $92 \%$. The Coastal SEG varies from 4 to $13 \%$ and the c/l ratio - from 0.1 to 0.4 .

A marked change is observed in the composition of palaeoflora. Lycopsids (Lycostrobus and Annalepis), showing a wide environmental tolerance (Grauvogel-Stamm, 1978; Orłowska-Zwolińska, 1979; Mader, 1990b, 1997), dominated in deltaic and lake coastal palaeobiocenoses (Visscher et al., 1993; Brugman et al., 1994). The wet hinterland was overgrown mainly by horsetails and ferns. Equisetites formed reed colonies along rivers and lake banks (Mader, 1990b, 1997). The dry hinterland, distant from sedimentary basins, was occupied by shrubby and arborescent conifers (Kustatscher and Van Konijnenburg-VanCittert, 2005).

\section{LONGDONENSIS ZONE}

Miospore spectra of the longdonensis zone were found in Lower Gipskeuper deposits from 23 boreholes (Fig. 7; Appendix 1).

The PPC model evidences that assemblages of the iliacoides subzone are strongly dominated by xerophytic elements: conifer pollen Ovalipollis ( $\mathrm{K}$ group) reaching even $80 \%$, Minutosaccus, Labiisporites and Cedripites (group P; Figs. 16, 17, 25-27 and 30-34; Appendix 9). Fern spores Leschikisporis (group A), Todisporites and Cyclotriletes (group B), Verrucosisporites, Anapiculatisporites and ?Echinitosporites (group C), equisetalean spores Calamospora (group B), and bryophyte spores Porcellispora (group F) are the main hygrophytic components. Cycadalean pollen (group $\mathrm{H}$ ) prevail among intermediate elements.

The PPC model shows marked dominance of the Upland SEG - in average $>60 \%$.

Compared to the dimorphus zone, a significant decrease of the $\mathrm{w} / \mathrm{d}$ ratio is observed. It varies from 0 to 7 (Figs. 16, 17, 25-27 and 30-34; Appendix 9) and indicates arid conditions in the latest Ladinian and earliest Carnian.

A general decrease of the Coastal SEG and c/l ratio is observed in the dimorphus zone. The low c/l ratio and presence of acritarchs in the Grenzdolomite deposits mark the latest Ladinian transgression in the Polish Basin. Assemblages of the verrucata subzone are composed most exclusively of xerophytic elements: conifer pollen Ovalipollis (group K), Triadispora (group N), Minutosaccus, Labiisporites, Cedripites (group P), Infernopollenites and Striatoabietites (group M) (Figs. 26, 31, 33 and 34; Appendix 9).

The very low $w / d$ ratio, in average of $<0.5$ (Figs. 16, 17, 25-27, 30-32 and 34; Appendix 9), suggests a a very dry climate in the Early Carnian.

In the SEG model, strong dominance of the Upland SEG - in average of $>80 \%$ - is observed.

Conifers occupied not only uplands but also, together with ferns, equisetales and cycads, moist to wet inland floodplains. Areas of higher salinity on the 


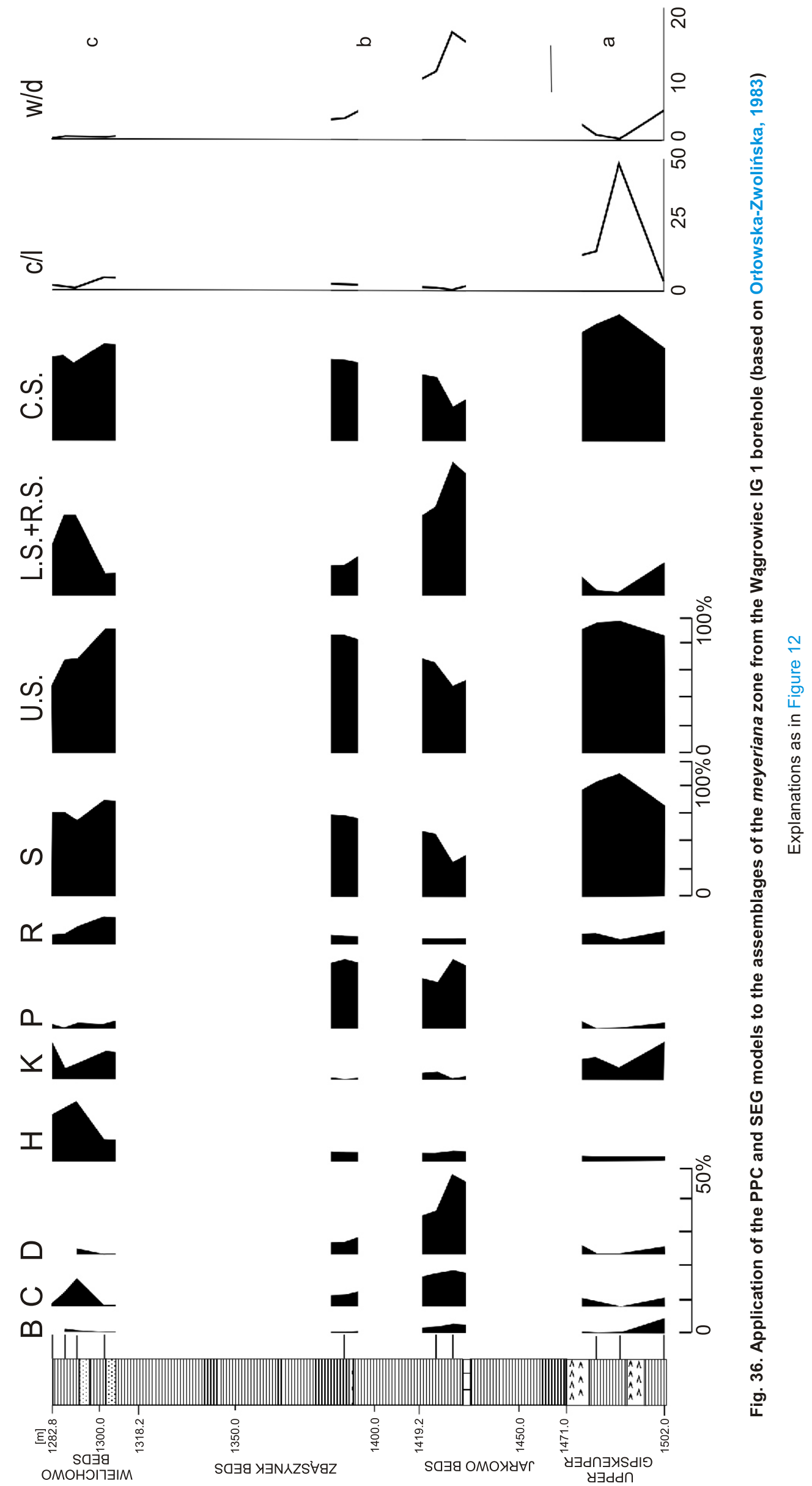


sabkha/playa coast, were overgrown by pioneer halophyte lycopsids.

ASTIGMOSUS ZONE

The material comes from Schilfsandstein (Stuttgart Formation) deposits of 13 boreholes (Fig. 8; Appendix 1).

Assemblages of the astigmosus zone are strongly dominated by hygrophytic elements (in average of $>80 \%$ ): ?equisetalean spores Aulisporites, equisetalean spores Calamospora, fern spores Todisporites (B group), fern spores Leschikisporites (A group), lycopsid spores Anapiculatisporites and fern spores Verrucosisporites (group C) as well as lycopsid spores Camarozonosporites (group D) and Aratrisporites (group E; Fig. 33; Appendix 10). Xerophytic elements are represented mainly by conifer pollen Ovalipollis (group $\mathrm{H}$ ), Brachysaccus and Labiisporites (group P).

The high w/d ratio >70 in some samples (Fig. 33; Appendix 10), indicates a humid climate and corresponds with the "Carnian pluvial event" (e.g., Kozur and Bachman, 2010; Roghi et al., 2010; Arche and Lópoez-Gómez, 2014).

The SEG model shows a strong dominance of the Lowland and River SEG and Coastal SEG. Ferns, equisetales, lycopsids and cycads inhabited moist to wet floodplains, areas of retarded drainage and those located at different distances from channels and lakes. Conifers colonised drier uplifted areas, with enhanced drainage and/or those located at greater distances from streams and pools, preferentially in basin margins or even on the flanks of erosional highlands (Mader, 1997).

\section{MEYERIANA ZONE}

Miospore assemblages of the meyeriana zone were found in the Upper Gipskeuper, Jarkowo Beds and the lower part of the Zbąszynek Beds, as well as their equivalents, in 13 boreholes (Fig. 9; Appendix 1).

The PPC model evidences that these assemblages from the upper part of the Upper Gipskeuper are strongly dominated by xerophytic circumpollen, mainly Classopollis and Granuloperculatipollis (group S) that accounts for 9 to $80 \%$ (Figs. 35-37; Appendix 11). Conifer pollen Ovalipollis (group $\mathrm{K}$ ), Cedripites and Labiisporites (group $\mathrm{P}$ ) occur less abundantly (in average of $>20 \%$ ). Scarce hygrophytic components consist of cycadalean and bennettitalean pollen of Cycadopites and Monosulcites (group H) as well as lycopsid spores (groups $\mathrm{D}$ and $\mathrm{E})$.

The $\mathrm{w} / \mathrm{d}$ ratio is distinctly lower in comparison to the astigmosus zone and varies from 0 to 12,3 on average (Figs. 35-37; Appendix 11), and indicates a dry climate in the Early Norian.

The SEG model shows dominance of the Upland SEG $(49-78 \%)$. The Coastal SEG is high and varies from 8 to $45 \%$. The $\mathrm{c} / \mathrm{l}$ ratio is also high and reaches even 48 , which reflects a regressive trend in the Polish Basin during the Early Norian.

A prominent change is observed in the composition of the palaeoflora, where the conifers Cheirolepidacean, producing pollen Classopollis, became a dominant element. They were drought-resistant trees and shrubs that occurred in a wide spectrum of environments: coastal, river, lowland and ?upland (Alvin, 1982; Abbink,1998). Dry lowland and upland areas and lagoon coastal zones were overgrown by other conifers, whereas lycopsids and cycads concentrated in the marginal zone of floodplains.

The assemblages of the meyeriana $\mathbf{b}$ subzones, identified in the Jarkowo Beds and the lower part of the Zbaszynek Beds,

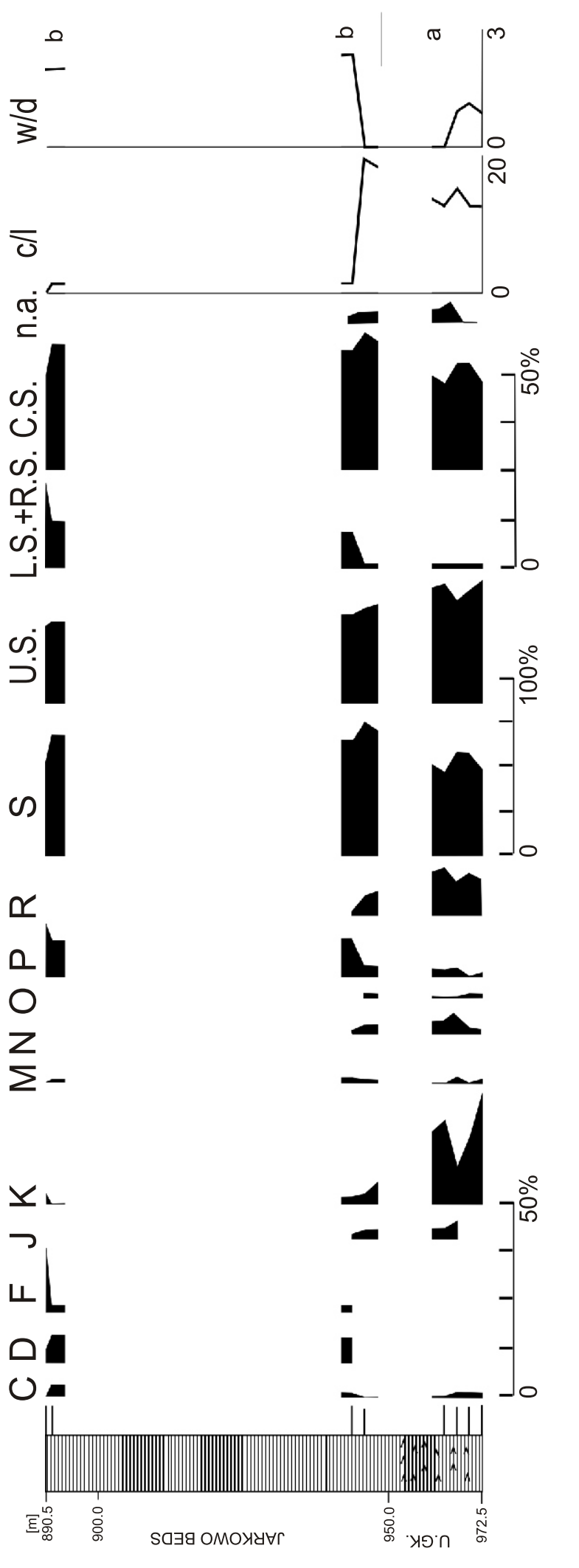




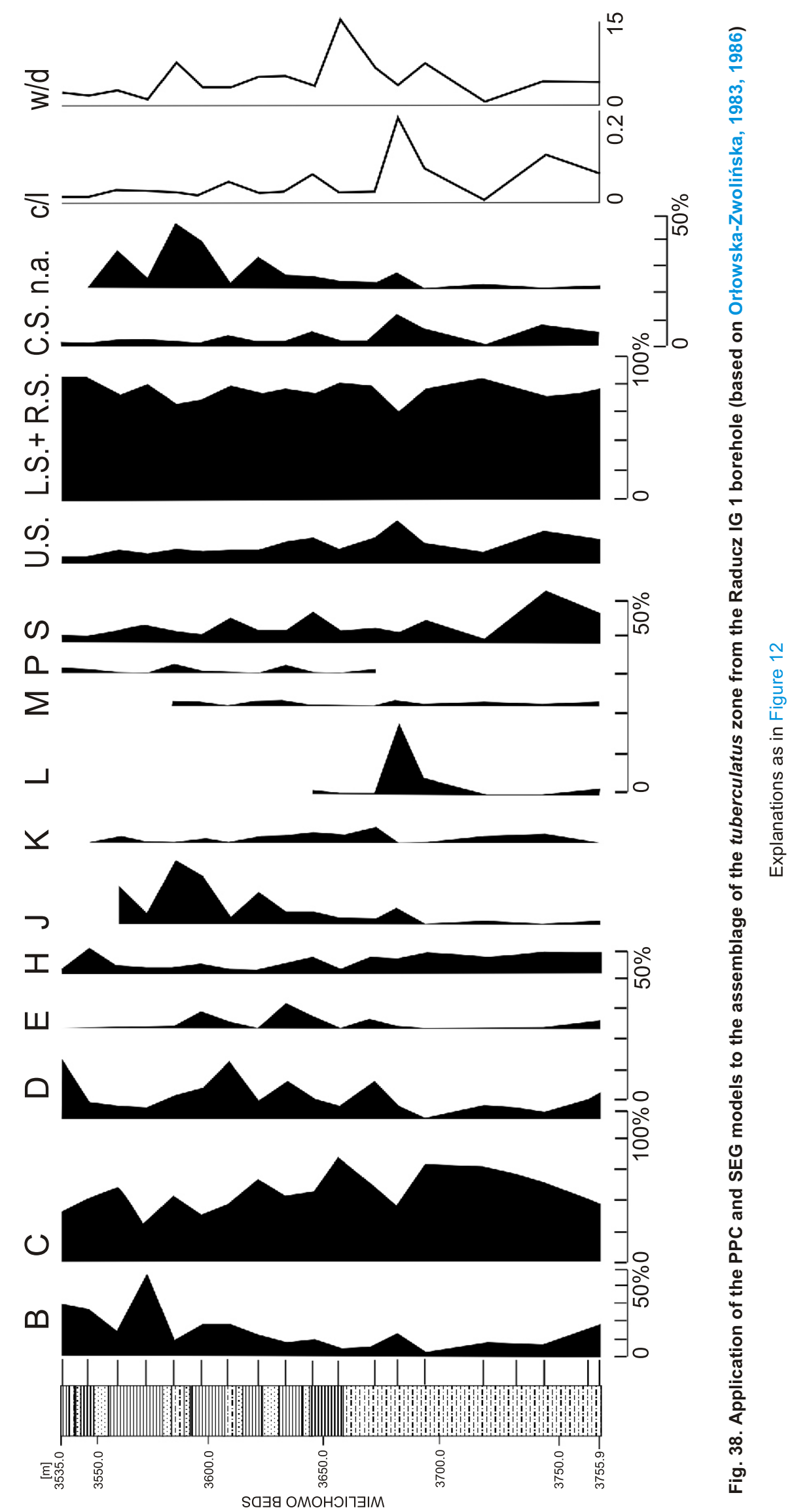


as well as their equivalents, show an increase in the amount of hygrophytic elements. Conifer pollen Brachysaccus, Cedripites (group P), Classopolls and Granuloperculatipollis (group S) still prevail in the miospore spectra (Figs. 35-37; Appendix 11). Hygrophytic components are dominated by lycopsid spores Densosporites (group D), Lycopodiumsporites (group C) and equisetalean spores Equisetumsporites (group B).

The w/d ratio increases even to18 and suggests the next pluvial event in the Late Norian (e.g., Berra et al., 2010; Preto et al., 2010).

The SEG model shows an increase of the Lowland and River SEG and a marked decrease of the Coastal SEG. The c/l ratio is low - in average of $<1$.

Moist to wet inland floodplain was occupied by lycopsids and equisetales. Dry uplands were covered with conifer forests consisting mainly of cedars. Cheirolepidacean formed bushfields along river banks and lagoon coastal zones (e.g., Abbink, 1998).

The assemblage of the meyeriana c subzone was found in the upper part of the Zbąszynek Beds only in the Wągrowiec IG 1 borehole (Fig. 9). It is strongly dominated by crircumpollen (group S; Fig. 36). Pollen Ovalipollis (group K) and cycadalean/bennettitalaen pollen Monosulcites (group H) are abundant.

The w/d ratio (0.5-2) visibly decreases in comparison to the meyeriana $\mathrm{b}$ subzone and indicates aridification of the Early Rhaetian climate (see Haas et al., 2012).

The SEG model shows an increase of Coastal SEG.

\section{TUBERCULATUS ZONE}

The material comes from the Wielichowo Beds and their equivalents from 8 boreholes (Fig. 10; Appendix 1).

Assemblages of the tuberculatus zone consist mainly of hygrophytic elements (in average more than 50\%) - fern spores Corrugatisporites, Marattisporites and Osmundacidites (group B), Deltoidospora (al. Cyathidites), Gleicheniidites and Todisporites (group A), lycopsid spores Camarozonosporites, Cingulizonates and Densosporites (group D) as well as intermediate forms such as cycadalean, bennettitalaen and ginkgoalean pollen Cycadopites, Chasmatosporites, Eucommiidites, Monosulcites, and Riccisporites (group H) accounting for up to $87 \%$ in some samples (Fig. 38; Appendix 12). Scarce xerophytic forms are represented by conifer pollen Pinuspollenites (group M), Ovalipollis (group $\mathrm{K}$ ) and circumpolles Classopollis (group S).

The $w / d$ ratio changes from very low and low values $(0.1-2)$ in the spectra from the lower part of the zone, to 8-25 in its upper part. An increase of humidity is due to climate pluvialisation in Late Rhaetian time (e.g., Michalík et al., 2010; Preto et al., 2010; Brański, 2011; Haas et al., 2012; Lintnerová et al., 2013; Pieńkowski et al., 2014; Szulc and Racki, 2015).

The SEG model evidences the strong dominance of the Lowland and River SEG - in average of $>80 \%$ and even $100 \%$ in some samples (Fig. 38; Appendix 12).

Moist to wet inland floodplain, swamps, river banks, margins of lakes and deltas were colonised by ferns, mosses, horsetails and lycopsids (e.g., Abbink, 1998; Van Konijnenburg-Van Cittert, 2002). These plants represented the ground cover habitat. Vegetation of the drier lowlands was composed mostly of cycads, bennetitales, taxodiaces, ferns (mainly Gleicheniaceae and Cyatheaceae) and seed ferns. These plants together with conifers are included into the mid and upper canopy habitat (Petersen et al., 2013). Scarce Pinaceae and Cheirolepidaceae occurred in dry hinterland and coastal environments (e.g., Kürschner, 2010; Götz et al., 2011; Bonis and Kürschner, 2012). A significant change in floral composition is observed in relation to the Late Norian biocenoses strongly dominated by gymnosperms Cheirolepidaceae. In the Rhaetian assemblages, spores are accompanied by numerous pollen Riccisporites tuberculatus Lundblad produced by ruderal, herbaceous conifers that were able to colonise disturbed habitats (Rothwell et al., 2000; Vajda et al., 2013). Although Kürschner et al. (2014) suggested that parent plants of $R$. tuberculatus preferred probably cooler climatic conditions in comparison to Cheirolepidiaceae producing pollen Classopolis, this change may be explained rather by a biotic crisis related to volcanic activity in the Central Atlantic magmatic province (e.g., Van de Schootbrugge et al., 2009; Bonis et al., 2010; Kürschner and Herngreen, 2010; Mander et al., 2013; Pálfy and Koscic, 2014; Pieńkowski et al., 2014). On the assumption of Early Rhaetian age of the meyeriana c subzone (see Kürschner and Herngreen, 2010), this floral turnover took place in the Early Rhaetian, whereas in literature it is worldwide dated as latest Rhaetian (Hubbard and Boutler, 2000; Hesselbo et al., 2002; Marzoli et al., 2004; Kliti et al., 2005; Deenen et al., 2010; Bonis and Kürschner, 2010, 2012; Blackburn et al., 2013).

\section{PALAEOCLIMATIC INTERPRETATION}

Dominance of xerophytic miospores and relatively high amount of Cycadopites pollen in assemblages of the obsoleta-pantii zone indicate a warm, semiarid climate during the Induan (Fijałkowska-Mader, 1999; Fig. 39). This suggestion corresponds with palaeoclimatic reconstructions for the Early Triassic, where Central and Western Europe is located within the subtropical climate zone, between 15 and $25^{\circ} \mathrm{N}$ (e.g., Frakes, 1979; Van der Zwan and Spaak, 1992; Ziegler et al., 1994; Zharkov and Chumakov, 2001; Chumakov and Zharkov, 2003; Sellwood and Valdes, 2007; Kürschner and Herngreen, 2010; Paul and Puff, 2010). According to Kutzbach and Gallimore (1989) the area of Poland was placed in the northern intertropical convergence zone with the monsoonal circulation characterized by strong seasonality of temperatures and precipitations (see also Parrish, 1993; Hermann et al., 2012). Relatively high temperatures could be explained not only by the palaeogeographical position of Poland but also by the global greenhouse effect which started in the Late Permian (e.g., Dickins, 1993; Racki and Wignal, 2005; Twitchett, 2007; Krassilov and Karsev, 2009; Hochuli et al., 2010; Preto et al., 2010).

Analysis of assemblages of the nejburgii and acritarchs subzone indicates that climatic conditions in the Early Olenekian (Early Smithian) remained similar to those in the Induan. Decreasing dominance of xerophytic miospores of the nejburgii subzone suggests an increase of humidity and a change from a warm semiarid to a subhumid climate during the Late Smithian (e.g., Dobruskina, 1994; Fig. 39). This humidity increase was suggested also by Yaroshenko (1977) on the basis of the worldwide expansion of Pleuromeiaceae. Other circumstances like the presence of abundant plant fossils, conchostraca and Chirotherium tracks in the Hardegsen Formation and its equivalents may also document the increasing humidity (Paul and Puff, 2010) and contradicts the global character of the "dry" episode at the Middle/Late Smithian boundary (e.g., Hermann et al., 2012). The further increase of humidity is observed in assemblages of the presselensis subzone (Spathian) and coincides with a "wet" pick on the climatic curve presented by Paul and Puff (2010). It does not confirm the 


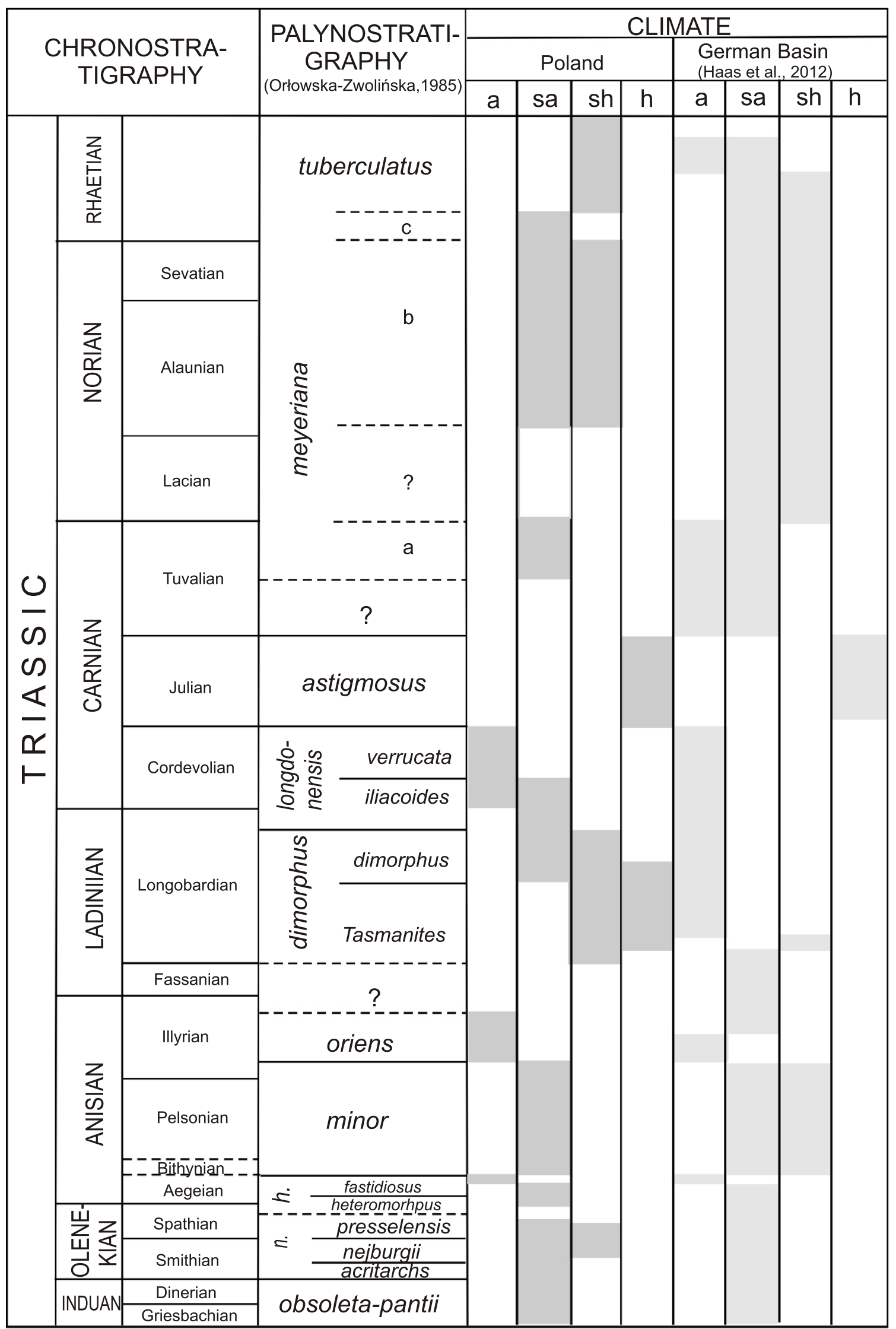

Fig. 39. Main climatic stages of Poland and the German Basin based on palynological data

Climate: a - arid, sh - semiarid, sh - subhumid, h - humid; palynological zones: $\mathrm{n}$. - nejburgii, h. - heteromorphus, ? - luck of data 
change from humid to drier conditions postulated by Hermann et al. $(2011 a, 2012)$ at the Smithian/Spathian boundary.

High differentiation of the w/d curves in the Late Olenekian spectra that may result from the climatic change at the Smithian/Spathian boundary (SSB event) from warm and equable conditions into more differentiated with greater temperature oscillations (e.g., Looy et al., 1999; Galfetii et al., 2007; Lindström and McLoughlin, 2007; Preto et al., 2010).

A distinct decrease of humidity to semiarid and arid conditions is observed in pollen assemblages of the heteromorphus zone (Early Anisian; Fig. 39).

Relatively low w/d ratio in assemblages of the minor zone confirms the semiarid climate of the Middle Anisian (Late Bithynian-Pelsonian) suggested by Frakes (1979), Kürschner and Herngreen (2010) and Haas et al. (2012). There is no evidence for a Bithynian humid episode in the Polish spectra (e.g., Haas et al., 2012; Fig. 39).

Compared to the Early Triassic, the area of Central and Western Europe was slightly moved towards the north between 25 and $30^{\circ}$ but still remained within the subtropical climate belt (Frakes, 1979; Ziegler et al., 1994).

The very low $w / d$ indicators in spectra of the oriens zone suggest an arid climate in the Illyrian (Fig. 39). A warm and very dry climate may also be proven by strong dominance of Triadispora pollen (e.g., Visscher et al. 1993; Kürschner and Herngreen, 2010). There is no evidence in the Polish assemblages for the Late Anisian humid event postulated by Hochuli and Vigran (2010) and Preto et al. (2010).

Based on the high w/d ratio values in assemblages of the Tasmanites subzone, the Middle Ladinian (Early Longobardian) climate can be determined as subhumid and humid (e.g., Grodzicka-Szymanko and Orłowska-Zwolińska, 1972; Orłowska-Zwolińska, 1983; Szulc, 1999; Preto et al., 2010; Fig. 39). This suggestion does not coincide with the semiarid climate postulated by Lindström et al. (2009), Hochuli and Vigran (2010) and Kürschner and Herngreen (2010). Preto et al. (2010) correlated the uppermost Muschelkalk and Lettenkeuper (Erfurt Formation) to the uppermost Ladinian and suggested a humid and warm climate for that time. After Feist-Burkhard et al. (2008: fig. 13.1) the Upper Muschelkalk is correlated to the uppermost Illyrian-Lower Longobardian, and the Lettenkeuper to the Lower-Middle Longobardian. Therefore, the warm and humid climate suggested by Preto et al. (2010) should be related rather to the Early than Late Ladinian.

According to Brugman et al. (1994) the high amount of hygrophytic components in the Late Ladinian miospore spectra may result rather from local environmental factors than climate changes but the composition of the Lowland and River SEG, containing mostly "more humid" taxa, suggests rather climatic causation (see also Kustatscher and Van Konijnenburg-Van Cittert, 2005). A gradual decrease of humidity is observed within the dimorphus subzone (Late Ladinian) from humid to semiarid conditions.

The very low $d / w$ ratio values in the spectra of the longdonensis zone suggest that the latest Ladinian climate was semiarid and became more dry and arid in the Early Carnian (Fig. 39) that agrees with palaeogeographic maps presented by Frakes (1979) and Ziegler et al. (1994) where the area of Central and Western Europe was placed at $30^{\circ} \mathrm{N}$ within the dry tropical climate belt.

Both the PPC model and the high $w / d$ ratio in the astigmosus zone indicate a humid and warm climate during the Late Julian, which corresponds to the "Carnian Pluvial Event" (Simms and Ruffell, 1989, 1990; Simms et al., 1995; Kozur and Bachmann, 2010; Preto et al., 2010; Roghi, 2004; Roghi et al., 2010; Haas et al., 2012).
The PPC model as well as low w/d ratio in the meyeriana a subzone indicate a warm semiarid climate in the Early Norian (Fig. 39), which coincides with observations of the other authors (e.g., Ahlberg et al., 2002; Berra et al., 2010; Preto et al., 2010; Brański, 2011, 2014; Pieńkowski et al., 2014; Szulc and Racki 2015). Vakhrameev $(1981,1987,1991)$ suggested that the high content of pollen Classopollis indicates an arid climate. This rule finds also confirmation in microflora from Poland (see Fig. 34).

Both the PPC model and the w/d ratio in the meyeriana $b$ subzone indicate an increase of humidity in the Late Norian (Fig. 39), which corresponds to the pluvial event (Berra et al., 2010; Preto et al., 2010; Szulc and Racki, 2015).

The lower $w / d$ ratio in the meyeriana c subzone reflects a return to a semiarid climate in the Early Rhaetian.

Predominance of hygrophytic elements in assemblages of the tuberculatus zone suggests a subhumid climate in the Late Rhaetian (Fig. 39). The change of climate from dry to wet in the Early Rhaetian was documented in many areas of Europe (e.g., Ahlberg, 2002; Berra et al., 2010; Michalík et al., 2010; Preto et al., 2010; Götz et al., 2011; Brański, 2011, 2014; Haas et al., 2012; Lintnerová et al., 2013; Krupnik et al., 2014; Pieńkowski et al., 2014). The author's observations do not confirm the decrease of humidity and arid to semiarid climate in the Late Rhaetian suggested by Haas et al. (2012).

During the Rhaetian, the area of Central and Western Europe was placed at $40^{\circ} \mathrm{N}$ in the subtropical, monsoonal climatic belt (Ziegler et al., 1994; Kent and Tauxe, 2005; Sellwood and Valdes, 2007; Bonis and Kürschner, 2012).

\section{CONCLUSIONS}

1. Application of the PPC model to the miospore assemblages from Poland allowed reconstructing the climate changes during the Triassic. The results obtained by author generally coincide with the palaeogeographical and palaeoclimatic reconstructions for Central and Northwestern Europe with the exception of the Middle Ladinian. The high w/d ratio in the Polish assemblages indicates a subhumid and humid climate.

2. Dominance of xerophytic elements in the palynomorph spectra reflects a persistent subtropical warm dry climate during most of the Triassic. significant proportions of hygrophytic elements in the microfloral assemblages document humid phases during the Late Olenekian, Middle/Late Ladinian, Middle Carnian, Late Norian and Late Rhaetian.

3. Application of the seg model enabled a rough reconstruction of the changes in palaeofloral communities. In the Induan, a ruderal strategy is observed by the colonisation of habitats destroyed in the Permian/Triassic crisis, mainly by lycopsids (lowland seg). A stress-tolerating strategy related to living in coastal environments (coastal SEG) dominated in the Olenekian. In the Early Anisian, the first significant reforestation after the Permo-Triassic crisis took place, accompanied by the renewal of conifers which dominated not only in the Upland SEG but occurred numerously also in the Lowland and Coastal SEGs. Dry climate and marine transgression in the Middle Anisian caused the strong dominance of the Upland SEG. This situation changed only in the Ladinian when the amount of lycopsids increased, and the Lowland and River SEG prevailed. At the same time, conifers developed a ruderal strategy by colonisation of xerophytic coastal habitats. The conditions favourable for plants deteriorated rapidly in the Early Carnian due to climate aridisation. The "Carnian Pluvial Event" in the Middle Carnian caused an expansion of equisetales - the main component of the Lowland and River SEG. The next arid phase in the 
Early Norian contributed to the expansion of xerophytic Cheirolepidacean which occupied a wide range of environments - Upland, Lowland and Coastal SEGs. In the Late Norian, a small humid impulse is marked by an increase of the amount of lycopsids and equisetales (Lowland and River SEG). The humid and warm climate of the Late Rhaetian favoured the development of ferns which dominated in the Lowland and River SEG.
4. A significant decrease of the number of saccate pollen in the Rhaetian tuberculatus zone, and a simultaneous sudden proliferation of ruderal Riccisporites tuberculatus may have occurred due to volcanic activity in the Central Atlantic Magmatic Province.

Acknowledgements. The author thanks E. Kustatscher, A. Becker and J. Szulc for valuable and helpful remarks.

\section{REFERENCES}

Abbink, O.A., 1998. Palynological investigations in the Jurassic of the North Sea region. Laboratory of Palaeobotany and Palynology Contribution Series, 8: 1-188.

Abbink, O.A., Van Konijnenburg-Van Cittert, J.H.A., Visscher, H., 2004a. A sporomorph ecogroup model for the northwest European Jurassic-Lower Cretaceous I: concepts and framework. Netherlands Journal of Geosciences, 83: 17-31.

Abbink, O.A., Van Konijnenburg-Van Cittert, J.H.A., Visscher, H., 2004b. A sporomorph ecogroup model for the northwest European Jurassic-Lower Cretaceous II: application to an exploration well from the Dutch North Sea. Netherlands Journal of Geosciences, 83: 81-91.

Ahlberg, A., Arndorff, L., Guy-Ohlson, D., 2002. Onshore climate change during the late Triassic marine inundation of the Central European Basin. Terra Nova, 14: 241-248.

Alvin, K.L., 1982. Cheirolepidiaceae: biology, structure and paleoecology. Review of Palaeobotany and Palynology, 37: 71-98.

Arche, A., López-Gómez, J., 2014. The Carnian Pluvial Event in West Europe: new data from Iberia and correlation with the Western Neotethys and Eastern North America-NW Africa regions. Earth-Sciences Reviews, 128: 196-231.

Bachmann, G.H., Geluk, M.C., Warrington, G., Becker-Roman, A., Beutler, G., Hagdorn, H., Hounslow, M.W., Nitsch, E., Röhling, H.-G., Simon, T., Szulc, A., 2010. Triassic. In: Petroleum Geological Atlas of the Southern Permian Basin Area (ed. J.C. Doornenbal and A.G. Stevenson): 149-173. EAGE Publications b.v. (Houten).

Balme, B.E., 1964. The age of the Wagina Sandstone, Irwin River District, Western Australia. The Australian Journal of Science, 27: 1-82.

Balme, B.E., 1995. Fossil in situ spores and pollen grains: an annotated catalogue. Review of Palaeobotany and Palynology, 87:1-323.

Becker, A., 2005. Sequenzstratigraphie und Fazies des Unteren und Mittleren Buntsandsteins im östlichen Teil des Germanischen Beckens (Deutschland, Polen). Hallesches Jahrbuch für Geowissenschaften, Reihe B, Beiheft, 21: 1-117.

Becker, A., Nawrocki, J., 2014. Magnetostratigraphy of the Buntsandstein (Lower Triassic) in the Gorzów Wielkopolski IG1 borehole, eastern German Basin in Poland: evidence of substantial diachronism of palynostratigraphic macrospore zones. Geological Quarterly, 58 (2): 369-378.

Berra, F., Jadoul, F., Anelli, A., 2010. Environmental control on the end of the Dolomia Principle/Hauptdolomit depositional system in the central Alps: coupling sea-level and climatic changes. Palaeogeography, Palaeoclimatology, Palaeoecology, 290: 138-150.

Beutler, G., Szulc, J., 1999. Die paläontologische Entwicklungdes Germanischen Becken in der Trias und die Verbindung zur Tethys. In: Trias, Eine Ganz Andere Welt: Mitteleuropa im Frühen Erdmittelalter (eds. N. Hauschke and V. Wilde): 71-80. Verlag Dr. Friedrich Pfeil, München.
Bilan, W., 1976. Stratigraphy of the Upper Triassic in the eastern margin of the Upper Silesian Coal Basin (in Polish with English summary). Zeszyty Naukowe AGH, Geologia, 2: 1-73.

Blackburn, T.J., Olsen, P.E., Bowring, S.A., McLean, N.M., Kent, D.V., Puffer, J., McHone, G.,Rasbury, E.T., Et-Touhami, M., 2013. Zircon U-Pb geochronology links the end-Triassic extinction with the Central Atlantic Magmatic Province. Science, 340: 941-945.

Bonis, N.R., 2010. Palaeoenvironmental changes and vegetation history during the Triassic-Jurassic transition. Laboratory of Palaeobotany and Palynology Contribution Series, 29: 1-216.

Bonis, N.R., Kürschner, W.M., 2010. Climate change driven black shale deposition during the end-Triassic in the western Tethys. Palaeogeography, Palaeoclimatology, Palaeoecology, 290: 151-159.

Bonis, N.R., Kürschner, W.M., 2012. Vegetation history, diversity patterns, and climate change across the Triassic/Jurassic boundary. Palaeobiology, 38: 240-264.

Bonis, N.R., Ruhl, M., Kürschner, W.M., 2010. Milankovich-scale palynological turnover across the Triassic/Jurassic transition at St. Audrie's Bay, SW UK. Journal of the Geological Society, 167: 877-888.

Boutler, M.C., Windle, T., 1993. A reconstruction of some Middle Jurassic vegetation in Northern Europe. Special Papers in Palaeontology, 49: 125-154.

Brański, P., 2011. Clay mineral composition in the Triassic and Jurassic deposits from the Polish Basin - a record of palaeoclimatic and palaeoenvironmental changes (in Polish with English summary). Biuletyn Państwowego Instytutu Geologicznego, 444: 15-32.

Brański, P., 2014. Climatic disaster at the Triassic-Jurassic boundary - a clay minerals and major elements record from the Polish Basin. Geological Quarterly, 58 (2): 291-310.

Brugman, W.A., 1986. A palynological characterization of the Upper Scythian and Anisian of the Transdsnubian Central Range (Hungary) and the Vicentinian Alps (Italy). Ph.D. thesis, University of Utrecht.

Brugman, W.A., Van Bergen, P.F., Kerp, J.H.F., 1994. A quantitative approach to Triassic palynology: the Lettenkeuper of the Germanic Basin as an example. In: Sedimentation of Organic Particles (ed. A. Traverse): 409-429. Cambridge University Press, Cambridge/New York.

Clement-Westernhof, J.A., 1974. In situ pollen from gymnospermous cones from the Upper Permian of the Italian Alps - a preliminary account. Review of Palaeobotany and Palynology, 17: 63-73.

Chumakov, N.M., Zharkov, M.A., 2003. Climate during the Permian-Triassic biosphere reorganizations. Article 2. Climate of the Late Permian and Early Triassic: general inferences. Stratigraphy and Geological Correlation, 11: 361-375.

Czapowski, G., Fijałkowska, A., 1993. Utwory pogranicza permu i triasu w SW Polsce w świetle badań sedymentologicznych i palinologicznych (in Polish). Przewodnik 2 Krajowego 
Spotkania Sedymentologów, (ed. K. Mastalerz): 147-148, Wrocław-Sudety, 4-7 września 1993.

Dadlez, R., 1962. Problem of the Triassic and Jurassic boundary in Western Poland (in Polish). Księga pamiątkowa ku czci prof. Jana Samsonowicza: 259-267. Polska Akademia Nauk, Warszawa.

Dadlez, R., 1972. Retyk (in Polish). Profile Głębokich Otworów Wiertniczych Instytutu Geologicznego, 2: 50-54, 76.

Dadlez, R., 1973. Retyk (in Polish). Profile Głębokich Otworów Wiertniczych Instytutu Geologicznego, 10: 33-36.

Dadlez, R., Kopik J., 1963. Problem of the Rhaetic in Western Poland in the light of the profile at Książ Wielkopolski (in Polish with English summary). Kwartalnik Geologiczny, 7 (1): 131-158.

Dadlez, R., Marek, S., Pokorski, J., 1998. Paleogeographical Atlas of the Epicontinental Permian and Mesozoic of Poland. Państwowy Instytut Geologiczny, Warszawa.

Deczkowski Z., 1977. Noryk i retyk. Sedimentacja, paleogeografia i paleotektonika. (in Polish). Prace Państwowego Instytutu Geologicznego, 153: 187-194.

Deczkowski, Z., 1983. Retyk (in Polish). Profile Głębokich Otworów Wiertniczych Instytutu Geologicznego, 57: 17.

Deczkowski, Z., 1998. Norian and Rhaetian. Sedimentation, palaeogeography and palaeotectonics (in Polish with English summary). Prace Państwowego Instytutu Geologicznego, 153 187-195.

Deenen, M.H.L., Ruhl, M., Bonis, N.R., Krijgsman, W., Kuerschner, W.M., Reitsma, M., Van Bergen, M.J., 2010. A new chronology for the end-Triassic mass extinction. Earth and Planetary Science Letters, 291: 113-125.

De Jersey, N.J., 1962. Triassic Spores and Pollen Grains from the Ipswich Coal-field. Geological Survey of Queensland Publication Series, 307: 1-18.

Dickins, J.M., 1993. Climate of the Late Devonian to Triassic. Palaeogeography, Palaeoclimatology, Palaeoecology, 100: 89-94

Dobruskina, I.A., 1994. Triassic Floras of Eurasia. Österreichische Akademie für Wissenschaften, Schriftenreihe der Erdwissenschaften Kommissionen, 10: 1-422.

Douglas, J.G., 1973. Spore-plant relationships in Victorian Mesozoic cryptogams. Geological Society of Australia Special Publications, 4: 119-126.

Feist-Burkhardt, S., Götz, A.E., Szulc, J., Borkhataria, R., Geluk, M., Haas, J., Hornung, J., Jordan, P., Kempf, O., Michalik, J., Nawrocki, J., Reinhardt, L., Ricken, W., Röhling, H.G., Rüffer, T., Török, Á., Zühlke, R., 2008. Triassic. The Geology of Central Europe, 2: 749-822. The Geological Society, London.

Feldman-Olszewska, A., 2014. Trias. Środkowy pstry piaskowiec (in Polish). Profile Głębokich Otworów Wiertniczych Państwowego Instytutu Geologicznego, 141: 88-106.

Fijałkowska, A., 1988. Wyniki badań sporowo-pyłkowych w profilu wiertniczym Mniszków IG 1 (płn. obrzeżenie Gór Świętokrzyskich) (in Polish). Kwartalnik Geologiczny, 32 (3/4): 751.

Fijałkowska, A., 1990. Wyniki badań sporowo-pyłkowych w profilu wiertniczym Tumlin-Podgrodzie IG 1 (zachodnia część Gór Świętokrzyskich) (in Polish). Kwartalnik Geologiczny, 34 (1): 199-200.

Fijałkowska, A., 1991. Microflora occurrence from the Nieświń PIG 1 borehole (NW marginof the Holy Cross Mts.) (in Polish). Geological Quarterly, 35 (4): 521-522.

Fijałkowska, A., 1992. Palynostratigraphy of the Keuper and Rhaetic in north-western margin of the Holy Cross Mountains. Geological Quarterly, 36 (2): 199-220.

Fijałkowska, A., 1993. Wyniki badań palinologicznych osadów triasu w profilu wiertniczym Opoczno PIG 2 (in Polish). Posiedzenia Naukowe Państwowego Instytutu Geologicznego, 49: 76-79

Fijałkowska, A., 1994a. Palynostratigraphy of the Lower and Middle Buntsandstein in NW part of the Holy Cross Mountains, Poland. Geological Quarterly, 38 (1): 59-96.
Fijałkowska, A., 1994b. Palynological aspects of the Permo-Triassic succession in the Holy Cross Mountains, Poland. Dokumenta Naturae, 87: 3-76.

Fijałkowska, A., 1995. Palynostratigraphy and palynofacies of the Permian/Triassic sequence in the Zary Pericline (SW Poland) Geological Quarterly, 39 (3): 307-332.

Fijałkowska, A., 2006a. Badania palinostratygraficzne permu, triasu i jury (in Polish). Profile Głębokich Otworów Wiertniczych Państwowego Instytutu Geologicznego, 111: 59-62.

Fijałkowska, A., 2006b. Badania palinostratygraficzne permu, triasu i jury (in Polish). Profile Głębokich Otworów Wiertniczych Państwowego Instytutu Geologicznego, 112: 63-65.

Fijałkowska-Mader, A., 1999. Palynostratigraphy, palaeoecology and palaeoclimate of the Triassic in South-Eastern Poland. Zentralblatt für Geologie und Paläontologie, I (1998): 601-627.

Fijałkowska-Mader, A., 2011. Palinostratygrafia permu górnego i triasu w niecce Nidy (in Polish). VI Świętokrzyskie Spotkania Geologiczno-Geomorfologiczne (eds. W. Trela, S. Salwa and A.Fijałkowska-Mader): 23, Ameliówka k. Kielc, 17-18 maja 2011.

Fijałkowska-Mader, A., 2013. Palynostratigraphy, paleoecology and paleoclimate of the late Permian and Triassic of the Nida Basin (in Polish with English summary). Biuletyn Państwowego Instytutu Geologicznego, 454: 15-70.

Fijałkowska, A., Kuleta, M., 1994. Palinostratygrafia oraz aspekty paleogeograficzne i paleoklimatyczne dolnego i środkowego pstrego piaskowca w NW części Gór Świętokrzyskich (in Polish). Posiedzenia Naukowe Państwowego Instytutu Geologicznego, 50: 115-116.

Fijałkowska, A., Trzepierczyńska, A., 1990. The palynostratigraphy of the Upper Permian and Triassic formations in the borehole Radwanów IG 1 (in Polish with English summary). Kwartalnik Geologiczny, 34 (4): 647-676.

Fijałkowska-Mader, A., Kuleta, M., Zbroja S., 2015. Lithostratigraphy, palynofacies and depositional environments of the Triassic deposits in the northern part of the Nida Basin, southern Poland (in Polish with English summary). Biuletyn Państwowego Instytutu Geologicznego, 462: 83-124.

Filatoff, J., 1975. Jurassic palynology of the Perth Basin, Western Australia. Palaeontographica B, 154: 1-113.

Frakes, L.A.,1979. Climates through Geologic Time. Elsevier, Amsterdam.

Franczyk M., 1986. Trias górny (in Polish). Profile Głębokich Otworów Wiertniczych Instytutu Geologicznego, 61: 63-65.

Gajewska, I., 1964. Roethian, Muschelkalk and Keuper in the Western and Central parts of the Fore-Sudetic Monocline - summary (in Polish with English summary). Kwartalnik Geologiczny, 8 (3): 598-608.

Gajewska I., 1972. Kajper (in Polish). Profile Głębokich Otworów Wiertniczych Instytutu Geologicznego, 2: 22-34.

Gajewska, I., 1973. Kajper (in Polish). Profile Głębokich Otworów Wiertniczych Instytutu Geologicznego, 10: 36-42.

Gajewska, I., 1977. Trias środkowy (wapień muszlowy-kajper). Sedimentology, palaeogeografia i paleotektonika (in Polish). Prace Instytutu Geologicznego, 153: 144-150.

Gajewska, I., 1978. Stratygrafia i rozwój kajpru w północno-zachodniej Polsce (in Polish with English summary). Prace Instytutu Geologicznego, 87: 5-56.

Gajewska, I., 1982. Kajper (in Polish). Profile Głębokich Otworów Wiertniczych Instytutu Geologicznego, 56: 33-39.

Gajewska, I., Peryt, T.M., Tomassi-Morawiec, H., 1985. Bromine content of the Keuper (Upper Triassic) salts in Central Poland indicates their marine (mainly second cycle) origin. Neues Jahrbuch für Geologie und Paläontologie Monatshefte, (6): 349-356.

Galfetti, T., Hochuli, P.A., Brayard, A., Bucher, H., Weissert, H., Vigran, J.O., 2007. Smithian-Spathian boundary event: Evidence for global climatic change in the wake of the end-Permian crisis. Geology, 35: 291-294.

Götz, A.E., Ruckwied, K., Barbacka, M., 2011. Palaeoenvironment of the Late Jurassic (Rhaetian) and Early Jurassic (Hettangian) 
Mecsek Coal Formation (south Hungary): implication from macro- and microfloral assemblages. Palaeobiology and Palaeoenvironments, 91: 75-88.

Grauvogel-Stamm, L., 1969. Nouveaux types d'organes reproducteurs mâles de coniferes du Grčs á Voltzia (Trias inférieur) des Vosges. Bulletin du Service de la Carte Geologique d' Alsace et de Lorraine, 22: 93-120, 355-357.

Grauvogel-Stamm, L., 1978. La flore du Grčs á Voltzia (Buntsandstein supérieur) des Vosges du Nord (France). Morphologie, anatomie, interpretation phylogénétique et paléogéographie. Sciencesgéologique: Mémoire, 50: 1-225.

Grauvogel-Stamm, L., 1999. Pleuromeia strenbergii (Munster) Corda, eine charakteristische Pflanze des deutschen Buntsandsteins. In: Trias, Eine Ganz Andere Welt, Mitteleuropa im Frühen Erdmittelalter (eds. N. Hauschke and V. Wilde): 271-282. Verlag Dr. Friedrich Pfeil, München.

Grauvogel-Stamm, L., Duringer, P., 1983. Annalepis zeilleri Fliche 1910 emend., un organe reproducteur de Lycophyte de la Lettenkohle de l'est de la France. Morphologie, species in situ et paléoécologie. Geologische Rundschau, 72: 23-51.

Grauvogel-Stamm, L., Grauvogel, L., 1973. Masculostrobus acuminatus nov. nom., un nouvel organe reproducteur du Grès á Voltzia (Trias inférieur) des Vosges (France). Geobios, 6 : 101-114.

Grauvogel-Stamm, L., Grauvogel, L., 1980. Morphologie et anatomie D' Anomoptyeris mougetii Brogniart (Synonymie: Pecopteris sultziana Brogniart): une fougère du Buntsandstein Supérieur des Vosges (France). Sciences Géologiques Bulletin, 33: 53-66.

Grodzicka-Szymanko, W., Orłowska-Zwolińska, T., 1972. Stratigraphy of the Upper Triassic in NE margin of the Upper Silesian Coal Basin (in Polish with English summary). Kwartalnik Geologiczny, 16 (1): 216-244

Haas, J., Budai, T., Raucsik, B., 2012. Climatic controls on sedimentary environments in the Triassic of the Transdanubian Range (Western Hungary). Palaeogeography, Palaeoclimatology, Palaeoecology, 353-355: 31-44.

Helby, R., Martin, A.R.H., 1965.Cyclostrobus gen.nov., cones of lycopsidea plants from the Narrabeen Group (Triassic) of New South Wales. Australian Journal of Botany, 13: 389-404.

Hermann, E., Hochuli, P.A., Bucher, H., Vigran, J.O., Weissert, H., Bernasconi, S.M., 2010. A close-up view of the Permian-Triassic boundary based on expanded organic carbon isotope records from Norway (Trøndelag and Finnmark Platform). Global and Planetary Change, 74: 156-167.

Hermann, E., Hochuli, P.A., Méhay, S., Bucher, H., Brühwiler, T., Ware, D., Hautmann, M., Roghi, G., ur-Rehman, K., Yaseen, A., 2011a. Organic matter and palaeoenvironmental signals during the Early Triassic biotic recovery: the Salt Range and Surgar Range records. Sedimentary Geology, 234: 19-41.

Hermann, E., Hochuli, P.A., Méhay, S., Bucher, H., Brühwiler, T., Hautmann, M., Ware, D., Roohi, G., 2011b. Terrestrial ecosystems on North Gondwana following the end-Permian mass extinction. Gondwana Research, 20: 630-637.

Hermann, E., Hochuli, P.A., Bucher, H., Brühwiler, T., Hautmann, M., Ware, D., Weissert, H., Roohi, G., Yaseen, A., ur-Rehman, K., 2012. Climatic oscillation at the onset of the Mesozoic inferred from palynological records from the North Indian Margin. Journal of the Geological Society, 169: 227-237.

Hesselbo, S.P., Robinson, S.A., Surlyk, F., Piasecki, S., 2002. Terrestrial and marine extinction at the Triassic-Jurassic boundary synchronized with major carbon-cycle perturbation: a link to initiation of massive volcanism? Geology, 30: 251-254.

Heunisch, C., 1990. Palynologie der Bohrung "Natzungen 1979", Blatt 4321 Borgholz (Trias; Oberer Muschelkalk 2, 3, Unterer Keuper). Neues Jahrbuch für Geologie und Paläontologie Monatshefte, (1): 17-42.

Hochuli, P.A., Vigran, J.O., 2010. Climate variations in the Boreal Triassic - Infered from palynological records from the Barents Sea. Palaeogeography, Palaeoclimatology, Palaeoecology, 290: $20-42$.
Hochuli, P.A., Vigran, J.O., Hermann, E., Bucher, H., 2010. Multiple climatic changes around the Permian-Triassic boundary event revealed by expanded palynological record from mid-Norway. GSA Bulletin, 122: 884-896.

Hubbard, R.N.L.B., Boulter, M.C., 2000. Phytogeography and palaeoecology in Western Europe and Eastern Greenland near the Triassic-Jurassic boundary. Palaios, 15: 120-131.

Jelen, B., Kušej, J., 1982. Quantitative palynological analysis of Julian clastic rocks from the lead-zinc deposits of Mezica. Geologia - Rozpravy Poročila, 25: 21-227.

Jurkiewicz, H., 1974a. Development of the Triassic in the central area of the Nida Trough (in Polish with English summary). Kwartalnik Geologiczny, 18 (1): 90-108.

Jurkiewicz, H., 1974b. Trias (in Polish). Profile Głębokich Otworów Wiertniczych Instytutu Geologicznego, 33: 13-32.

Jurkiewicz, H., 1976. Trias (in Polish). Profile Głębokich Otworów Wiertniczych Instytutu Geologicznego, 33: 13-32.

Jurkiewicz, H., 1980a. Trias (in Polish). Profile Głębokich Otworów Wiertniczych nstytutu Geologicznego, 51: 13-24.

Jurkiewicz, H., 1980b. Trias (in Polish). Profile Głębokich Otworów Wiertniczych Instytutu Geologicznego, 52: 11-27.

Jurkiewicz, H., 1988. Trias (in Polish). Profile Głębokich Otworów Wiertniczych Instytutu Geologicznego, 64: 12-59.

Jurkiewicz, H., 1990. Trias (in Polish). Profile Głębokich Otworów Wiertniczych Państwowego Instytutu Geologicznego, 70: 12-24.

Jurkiewicz, H., 1991. Trias (in Polish). Profile Głębokich Otworów Wiertniczych Państwowego Instytutu Geologicznego, 74: 11-21.

Jurkiewicz, H., 1993. Trias (in Polish). Profile Głębokich Otworów Wiertniczych Państwowego Instytutu Geologicznego, 76: $11-48$.

Jurkiewicz, H., 1994. Trias (in Polish). Profile Głębokich Otworów Wiertniczych Państwowego Instytutu Geologicznego, 77: 12-25.

Jurkiewicz, H., 1995. Trias (in Polish). Profile Głębokich Otworów Wiertniczych Państwowego Instytutu Geologicznego, 80: 10-18.

Jurkiewicz, H., 1999. Trias (in Polish). Profile Głębokich Otworów Wiertniczych Państwowego Instytutu Geologicznego, 92: 12-25.

Jurkiewicz, H., Woiński, J., 1976. Trias (in Polish). Profile Głębkich Otworów Wiertniczych Instytutu Geologicznego, 34: 13-34.

Kelber, K.P., Van Konijnenburg-Van Cittert, J.H.A., 1998 Equisetites arenaceus from the Upper Triassic of Germany with evidence for reproductive strategies. Review of Palaeobotany and Palynology, 100: 1-26.

Kent, D.V., Tauxe, L., 2005. Corrected Late Triassic latitudes for continents adjacent to the North Atlantic. Science, 307: 240-244.

Kliti, G., Backhouse, J., Alexander, R., Marshall, N., Logan, G.A., 2005. Correlating terrestrial signatures from biomarker distributions, $\delta^{13} \mathrm{C}$, and palynology in fluvio-deltaic deposits from NW Australia (Traissic-Jurassic). Organic Geochemistry, 36: 1347-1358.

Knox, E.M., 1950. The spores of Lycopsidium, Phylloglossum, Selaginella and Isoëtes and their value in the study of microfossils of Palaeozoic origin. Transactions and Proceedings of the Botanical Society of Edinburgh, 35: 209-357.

Kopik, J., Senkowiczowa, H., 1973. Trias pozakarpacki (in Polish). In: Budowa Geologiczna Polski, 1, Stratygrafia, cz. 2. Mezozoik (ed. S. Sokołowski): 15-118. Wyd. Geol., Warszawa.

Kozur, H.W., Bachmann, G.H., 2010. The Middle Carnian Wet Intermezzo of the Stuttgart Formation (Schilfsandstein), Germanic Basin. Palaeogeography, Palaeoclimatology, Palaeoecology, 290: 107-119.

Kozydra, Z., 1962. Contact of Triassic and Jurassic deposits in borehole Eugeniów near Gorwczów (in Polish with English summary). Kwartalnik Geologiczny, 6 (3): 460-468.

Krassilov, V., Karasev, E., 2009. Paleofloristic evidence of climate change near and beyond the Permian-Triassic boundary. 
Palaeogeography, Palaeoclimatology, Palaeoecology, 284: 326-336.

Krupnik, J., Ziaja, J., Barbacka, M., Feldman-Olszewska, A., Jarzynka, A., 2014. A palaeoenvironmental reconstruction based on palynological analyses of Upper Triassic and Lower Jurassic sediments from the Holy Cross Mountains region. Acta Palaeobotanica, 54: 35-65.

Kuleta, M., 1994. Dolny i środkowy pstry piaskowiec w otworze wiertniczym Opoczno PIG 2 (in Polish). Posiedzenia Naukowe Państwowego Instytutu Geologicznego, 50: 109-110.

Kuleta, M., 2006a. Środkowy pstry piaskowiec (in Polish). Profile Głębokich Otworów Wiertniczych Państwowego Instytutu Geologicznego, 111: 20-24.

Kuleta, M., 2006b. Środkowy pstry piaskowiec (in Polish). Profile Głębokich Otworów Wiertniczych Państwowego Instytutu Geologicznego, 112: 23-25.

Kuleta, M., Iwanow A., 2006a. Kajper i "retyk" (in Polish). Profile Głębokich Otworów Wiertniczych Państwowego Instytutu Geologicznego, 111: 13-15.

Kuleta, M., Iwanow A., 2006b. Kajper i "retyk" (in Polish). Profile Głębokich Otworów Wiertniczych Państwowego Instytutu Geologicznego, 112: 15-19.

Kuleta, M., Zbroja, S., 2006. Wczesny etap rozwoju pokrywy permsko-mezozoicznej w Górach Świętokrzyskich (in Polish). In: Procesy i zdarzenia w historii geologicznej Gór Świętokrzyskich (eds. S. Skompski and A. Żylińska): 105-125. 77 Zjazd Naukowy PTG, Ameliówka k. Kielc, 28-30 czerwca 2006 r. Państwowy Instytut Geologiczny, Warszawa.

Kustatscher, E., Van Konijnenburg-Van Cittert, J.H.A., 2005. The Ladinian flora (Middle Triassic) of the Dolomites: palaeoenvironmental reconstructions and palaeoclimatic considerations. Geo. Alp, 2: 31-51.

Kustatscher, E., Van Konijnenburg-Van Cittert, J.H.A., Roghi, G., 2010. Macrofloras and palynomorphs as possible proxies for palaeoclimatic and palaeoecological studies: a case study from the Pelsonian (Middle Triassi) of Kühwiesenkopf/Monte Prà della Vacca (Olang Dolomites, N-Italy). Palaeogeography, Palaeoclimatology, Palaeoecology, 290: 71-80.

Kustatscher, E., Heunisch, C., Van Konijnenburg-Van Cittert J.H.A., 2012. Taphonomical implications of the Ladinian megraflora and palynoflora of Thale (Germany). Palaios, 27 753-764.

Kutzbach, J.E., Gallimore, R.G., 1989. Pangaean climate: megamonsoons of the megacontinent. Journal of Geophysical Research, 94D: 3341-3357.

Kürschner, W.M., 2010. Vegetation history, diversity patterns, and climate changes across the Triassic-Jurassic boundary. Laboratory of Palaeobotany and Palynology Contribution Series, 29: 140-165.

Kürschner, W.M., Hergreen, G.F.W., 2010. Triassic palynology of central and northwestern Europe: a review of palynological diversity patterns and biostratigraphic subdivisions. Geological Society Special Publications, 334: 263-283.

Kürschner, W.M., Mander, L., McElwain, J.C., 2014. A gymnosperm affinity of Riccisporites tuberculatus Lundblad: implications for vegetation and environmental reconstructions in the Late Triassic. Palaeobiology and Palaeoenvironments, doi: $10.1007 / \mathrm{s} 12549-014-0163 y$

Larsson, L.M., 2009. Palynostratigraphy of the Triassic-Jurassic transition in southern Sweden. Geologiska Föreningens i Förhandlinger, 131: 147-163.

Lindström, S., McLoughlin, S., 2007. Synchronous palynofloristic extinction and recovery after the end-Permian event in the Prince Charles Mountains, Antarctica: implications for palynofloristic turnover across Gondwana. Review of Palaeobotany and Palynology, 145: 89-122.

Lindström, S., Vosgerau, H., Piasecki, S., Nielsen, L.H., Dybkjær, K., Erlström, M., 2009. Ladinian palynofloras in the Norwegian-Danish Basin: a regional marker reflecting a climate change. Geological Survey of Denmark and Greenland Bulletin, 17: $21-24$.
Lintnerová, O., Michalík, J., Uhlík, P., Soták, J., Weissová, Z., 2013. Latest Triassic climate humidification and kaolinite formation (Western Carpathians, Tatric Unit of the Tatra Mts.). Geological Quarterly, 57 (4): 701-728.

Looy, C.V., Brugman, W.A., Dichler, D.L., Visscher, H., 1999. The delayed resurgence of equatorial forests after the Permian-Triassic ecologic crisis. National Academy of Sciences of the United States of America Proceeding, 96: 13857-13862.

Looy, C.L., Collinson, M.E., Van Konijnenburg-Van Cittert, J.H.A., Visscher, H., Brain, A.P.R., 2005. The ultrastructure and botanical affinity of end-Permian spore tetrads. International Journal of Planetary Sciences, 166: 875-887.

Lucas, S.G., 2010. The Triassic timescale: an introduction. Geological Society Special Publications, 334: 1-16.

Lund, J.J., 1977. Rhaetic to Lower Liassic palynology of the onshore south-eastern North Sea Basin. Danmarks Geologiske Undersogelse II, 109: 1-129.

Lundblad, B., 1950. Studies in the Rhaeto-Liassic floras of Sweden. Kongliga Svenska Vetenskaps Akademien Handlingar, 1: $1-82$.

Lundblad, B., 1954. Contributions to the geological history of the Hepaticae. Fossil Marchiantiales from the Rhaetic-Liassic coal mines of Skromberga (Prov. of Scania). Sweden. Svensk Botanisk Tidskrift, 48: 381-417.

Mader, D., 1990a. Buntsandstein. Palaeoecology of the flora in Buntsandstein and Keuper in the Triassic of Middle Europe, 1 1-936. Fischer, Stuttgart/New York.

Mader, D., 1990b. Keuper and Index. Palaeoecology of the flora in Buntsandstein and Keuper in the Triassic of Middle Europe, 2: 937-1582. Fischer, Stuttgart/New York.

Mader, D., 1997. Palaeoenvironmental evolution and bibliography of the Keuper (Upper Triassic) in Germany, Poland and other parts of Europe. Loga, Köln.

Mädler, K., 1964. Die geologische Verbreitung von Sporen and Pollen in der Deutschen Trias. Beihefte zum Geologischen Jahrbuch, 65: 1-147.

Mander, L., 2011. Taxonomic resolution of the Triassic-Jurassic sporomorphs record in East Greenland. Journal of Micropalaeontology, 30: 107-118.

Mander, L., Collinson, M.E., Chaloner, W.G., Brain, A.P.R., Long, D.G., 2012. The ultrastructure and botanical affinity of the problematic mid-Mesozoic palynomorph Risscisporites tuberculatus Lundblad. International Journal of Plant Sciences, 173: $429-440$.

Mander, L., Kürschner, W.M., McElwain, J.C., 2013. Palynostratigraphy and vegetation history of the Triassic-Jurassic transition in East Greenland. Journal of the Geological Society, 170: 37-46.

Marzoli, A., Bertrand, H., Knight, K.B., Cirilli, S., Buratti, N., Vérati, C., Nomade, S., Renne, P.R., Youbi, N., Martini, R., Allenbach, K., Neuwerth, R., Rapaille, C., Zaninetti, L., Bellieni, G., 2004. Synchrony of the Central Atlantic magmatic province and the Triassic-Jurassic boundary climatic and biotic crisis. Geology, 32: 973-976.

Meyen, S.V., 1981. Some true and alleged Permotriassic conifers of Siberia and the Russian Platform and their alliance. Palaeobotanist, 28-29: 161-176.

Meyen, S.V., 1987. Fundamentals of Palaeobotany. Chapman and Hall, London.

Michalík, J., Biroň, A., Lintnerová, O., Götz, A.E., Ruckwied, K., 2010. Climate change at the Triassic/Jurassic boundary in the northwestern Tethyan Realm, inferred from sections in the Tatra Mountains (Slovakia). Acta Geologica Polonica, 60: 535-548.

Orłowska-Zwolińka, T., 1972a. Stratigraphy of the Keuper deposits from bore hole Boża Wola on the basis of spore-and-pollen analysis (in Polish with English summary). Kwartalnik Geologiczny, 16 (2): 301-314

Orłowska-Zwolińska, T., 1972b. Wyniki badań stratygraficznopalynologicznych osadów kajpru i retyku w profilach Sulechów, Zbąszynek i Międzychód (in Polish). Profile Głębokich Otworów Wiertniczych Instytutu Geologicznego, 2: 99-106. 
Orłowska-Zwolińska, T., 1977. Palynological correlation of the Bunter and Muschelkalk in selected profiles from Western Poland. Acta Geologica Polonica, 27: 417-430.

Orłowska-Zwolińska, T., 1979. Miospory (in Polish). Budowa Geologiczna Polski, 3, Mezozoik, cz. 2a, Trias: 166-200. Wyd. Geol., Warszawa.

Orłowska-Zwolińska, T., 1982. Wyniki badań mikroflorystycznych triasu w profilu Środa IG 2 (in Polish). Profile Głębokich Otworów Wiertniczych Instytutu Geologicznego, 56: 65-68.

Orłowska-Zwolińska, T., 1983. Palynostratigraphy of the upper part of Triassic epicontinental sediments in Poland (in Polish with English summary). Prace Instytutu Geologicznego, 104: 1-89.

Orłowska-Zwolińska, T., 1984. Palynostratigraphy of the Buntsandstein in section of Western Poland. Acta Palaeontologica Polonica, 29: 161-194.

Orłowska-Zwolińska, T., 1985. Palynological zones of the Polish epicontinental Triassic. Bulletin of Polish Academy of Sciences, Earth Sciences, 33: 107-119.

Orłowska-Zwolińska, T., 1986. Wyniki badań palinologicznych retyku i dolnego liasu w profilu otworu Raducz IG 1 (in Polish). Profile Głębokich Otworów Wiertniczych Instytutu Geologicznego, 61: 70-72.

Orłowska-Zwolińska, T., 1988. Palynostratigraphy of Triassic deposits in the vincinity of Brzeg (SE part of the Fore-Sudetic monocline) (in Polish with English summary). Kwartalnik Geologiczny, 32 (2): 349-366.

Parrish, J.T., 1993. Climate of the Supercontinent Pangea. Journal of Geology, 101: 215-233.

Paul, J., Puff, P., 2010. Das Klima im Buntsandstein. Schriften der deutschen Gesellschaft des Geowissenschaften, 69: 58-69.

Pedersen, K.R., Crane, P.R., Friis, E.M., 1989. Pollen organs and seeds with Eucommiidites pollen. Grana, 28: 279-294.

Pedersen, K.R., Lund, J.J., 1980. Palynology of the plant-bearing Rhaetian to Hettangian Kap Stewart Formation, Scoresby Sund, East Greenland. Review of Palaeobotany and Palynology, 31: $1-69$.

Petersen, H.I., Lindström, S., Therkelsen, J., Pedersen, G.K., 2013. Deposition, floral composition and sequence stratigraphy of uppermost Triassic (Rhaetian) coastal coals, southern Sweden. International Journal of Coal Geology, 116-117: 117-134.

Pálfy, J., Koscic, Á.T., 2014. Volcanism of the Central Atlantic magmatic province as the trigger of environmental and biotic changes around the Triassic-Jurassic boundary. GSA Special Papers, 505: 245-263.

Pieńkowski, G., 1991. Facies criteria for delimitating Zechstein/Buntsandstein and Permian/Triassic boundaries in Poland. Zentralblatt für Geologie und Paläontologie, (1): 893-912.

Pieńkowski, G., Niedźwiedzki, G., Brański, P., 2014. Climatic reversals related to the Central Atlantic magmatic province caused the end-Triassic biotic crisis - evidence from continental strata in Poland. GSA Special Papers, 505: 263-286.

Potonié, R., 1967. Versuch der Einordnung der fossilen Sporae dispersae in das phylogenetischen System der Pflanzenfamilien. Forschungsberichten Landes NordrheinWestfalen, 1761: 1-310.

Preto, N., Kustatscher, E., Wignall, P.B., 2010. Triassic climates state of the art and perspectives. Palaeogeography, Palaeoclimatology, Palaeoecology, 290: 1-10.

Racki, G., Wignall, P.B., 2005. Late Permian double-phased mass extinction and volcanism: an oceanographic perspective. In: Understanding Late Devonian and Permian-Triassic Biotic and Climatic Events: Towards an Integrated Approach (eds. J. Over, J.R. Morrow and P.B. Wignall): 263-297. Elsevier B.V.

Raine, J.I., De Jersey, N.J., Ryan, K.G., 1988. Ultrastructure and lycopsid affinity of Densoisporites psilatus (de Jersey) comb. nov. from the Triassic of New Zealand and Queensland. Memoir of Association of the Australasian Palaeontologists, 5: 79-88.

Reinhardt, L., Ricken, W., 2000. Climate cycles documented in a playa system: comparison of geochemical signatures derived from subbasins (Triassic, Middle Keuper, German Basin). Zentralblatt für Geologie und Paläontologie, (1): 315-340.

Roghi, G., 2004. Palynological investigations in the Carnian of the Cave del Predil area (Julian Alps, NE Italy). Review of Palaeobotany and Palynology, 132: 1-35.

Roghi, G., Gianolla, P., Minarelli, L., Pilati, C., Preto, N., 2010. Palynological correlation of Carnian humid pulses through western Tethys. Palaeogeography, Palaeoclimatology, Palaeoecology, 290: 89-106.

Romanek, M., 2006a. Wapień muszlowy i górny pstry piaskowiec (in Polish). Profile Głębokich Otworów Wiertniczych Państwowego Instytutu Geologicznego, 111: 15-20.

Romanek, M., 2006b. Wapień muszlowy i górny pstry piaskowiec (in Polish). Profile Głębokich Otworów Wiertniczych Państwowego Instytutu Geologicznego, 112: 19-23.

Rothwell, G.W., Grauvogel-Stamm, L., Mapes, G., 2000. An herbaceous fossil conifer: gymnospermous ruderals in the evolution of Mesozoic vegetation. Palaeogeography, Palaeoclimatology, Palaeoecology, 156: 139-145.

Ruckwied, K., 2009. Palynology of Triassic/Jurassic boundary key sections of the NW Tethyan Realm (Hungary and Slovakia). Ph.D. Thesis, TU Darmstadt, D17.

Scheuring, B.W., 1970. Palynologische und palyno-stratigraphische Utersuschungen des Keupers im Bölchentunnel (Solothurner Jura). Schweizerische Paläontologische Abhandlungen, 88: 1-187.

Sellwood, B.W., Valdes, R.I., 2007. Mesozoic climates.In: Deep-Time Perspectives on Climatic Changes: Marrying the Signal from Computer Models and Biological Proxies (eds. M. Williams, W.M. Haywood, F.J.M. Gregory and D.N. Schmidt): 201-224. The Micropalaeontological Society Special Publications, The Geological Society, London.

Senkowiczowa, H., 1965. Stratigraphy of the Roethian deposits in the area of the Fore-Sudetic Monocline (in Polish with English summary). Kwartalnik Geologiczny, 9 (4): 745-758.

Simms, M.J., Ruffel, A.H., 1989. Synchroneity of climatic change and extinction in the Late Triassic. Geology, 17: 265-268.

Simms, M.J., Ruffel, A.H., 1990. Climatic and biotic change in the late Triassic. Journal of the Geological Society, 147: 321-327.

Simms, M.J, Ruffel, A.H., Johnson, L.A., 1995. Biotic and climatic changes in the Carnian (Triassic) of Europe and adjacent areas. In: In the Shadow of the Dinosaurs: Early Mesozoic Tetrapods (eds. N.C. Fraser and H.D. Sues): 352-365. Cambrigde University Press, Cambridge.

Sokołowski, J., 1967. Geology and structure of Sudetic foreland (in Polish with English summary). Geologia Sudetica, 3: 297-367.

Szulc, J., 1999. Anisian-Carnian evolution of the Germanic basin and its eustatic, tectonic and climatic controls. Zentralblatt für Geologie und Paläontologie, (1): 813-852.

Szulc, J., 2000. Middle Triassic evolution of the northern Peri-Tethys area as influenced by early opening of the Tethys Ocean. Annales Societatis Geologorum Poloniae, 70: 1-48.

Szulc, J., 2014. Trias środkowy (in Polish). Profile Głębokich Otworów Wiertniczych Państwowego Instytutu Geologicznrgo, 141: 77-88.

Szulc, J., Racki, G., 2015. Grabowa Formation - the basic lithostratigraphic unit of the Upper Silesian Keuper (in Polish with English summary). Przegląd Geologiczny, 63: 103-113.

Szyperko-Śliwczyńska, A., 1972. Trias. Pstry piaskowiec (in Polish). Profile Głębokich Otworów Wiertniczych Instytutu Geologicznego, 1: 24-47.

Szyperko-Śliwczyńska, A., 1973. Correlation of the lower and middle Buntsandstein sections in West Poland (in Polish with English summary). Kwartalnik Geologiczny, 17 (2): 261-275.

Szyperko-Śliwczyńska, A., 1974. Trias. Pstry piaskowiec (in Polish). Profile Głębokich Otworów Wiertniczych Instytutu Geologicznego, 14: 150-155.

Szyperko-Śliwczyńska, A., 1977. Trias dolny (pstry piaskowiec). Sedymentologia, paleogeografia i paleotektonika (in Polish). Prace Instytutu Geologicznego, 153: 121-132. 
Szyperko-Śliwczyńska, A., 1979. Lower Trias in north-eastern Poland (in Polish with English summary). Prace Instytutu Geologicznego, 91: 1-77.

Szyperko-Teller, A., 1982. Lithostratigraphy of the Buntsandstein in the Western Pomerania (in Polish with English summary). Kwartalnik Geologiczny, 26 (2): 341-368.

Szyperko-Teller, A., 1997. Dolny trias (pstry piaskowiec). Sedymentacja, paleogeografia i paleotektonika. (in Polish). Prace Państwowego Instytutu Geologicznego, 153: 121-130.

Tralau, H., 1968. Some middle Jurassic miospores of southern Sweden. Geologiska Föreningens i Stockholm Förhandlinger, 89: 469-472.

Twitchett, R.J., 2007. Climate change across the Permian/Triassic boundary. In: Deep-Time Perspectives on Climatic Changes: Marrying the Signal from Computer Models and Biological Proxies (eds. M. Williams, A.M. Haywood, F.J.M. Gregory and D.N Schmidt): 191-200. The Micropalaeontological Society Special Publications, The Geological Society, London.

Vajda, V., Calner, M., Ahlberg, A., 2013. Palynostratigraphy of dinosaur footprint-bearing deposits from the Triassic-Jurassic boundary interval of Sweden. Geologiska Föreningens Förhandlinger, 135: 120-130.

Vakhrameev, V.A., 1981. Pollen Classopolis: Indicator of Jurassic and Cretaceous climates. The Palaeobotanist, 28-29: 301-307.

Vakhrameev, V.A., 1987. Climates and distribution of some gymnosperms in Asia during the Jurassic and Cretaceous. Review of Palaeobotany and Palynology, 51: 205-212.

Vakhrameev, V.A., 1991. Jurassic and Cretaceous Floras and Climates of the Earth. Cambridge University Press, Cambridge.

Van Bergen, P.F., Kerp J.H.P., 1990. Palynofacies and sedimentary environments of a Triassic section in Southern Germany. The Netherlands Mededelingen Rijks Geologische Dienst, 45: 23-37.

Van der Zwan, C.J., Spaak, P., 1992. Lower to Middle Triassic sequence stratigraphy and climatology of the Netherlands, a model. Palaeogeography, Palaeoclimatology, Palaeoecology, 91: $277-290$

Van Konijnenburg-Van Cittert, J.H.A., 1971. In situ gymnosperm pollen from the Middle Jurassic of Yorkshire. Acta Botanica Nederlandica, 20: 1-97.

Van Konijnenburg-Van Cittert, J.H.A., 1978. Osmundaceous spores in situ from the Jurassic of Yorkshire, England. Review of Palaeobotany and Palynology, 26: 125-141.

Van Konijnenburg-Van Cittert, J.H.A., 1987. New data on Pagiophyllum maculosum Kendall and its male cone from the Jurassic of North Yorkshire. Review of Palaeobotany and Palynology, 51: 95-105.

Van Konijnenburg-Van Cittert, J.H.A., 1989. Dicksoniaceous spores in situ from the Jurassic of Yorkshire, England. Review of Palaeobotany and Palynology, 61: 273-301.

Van Konijnenburg-Van Cittert, J.H.A., 1993. A review of the Matoniaceae based on in situ spores. Revew of Palaeobotany and Palynology, 78: 235-267.
Van Konijnenburg-Van Cittert, J.H.A., 2002. Ecology of some Late Triassic to Early Cretaceous ferns in Eurasia. Review of Palaeobotany and Palynology, 119: 113-124.

Van Konijnenburg-Van Cittert, J.H.A., 2008. The Jurassic fossil plant record of the UK area. Proceedings of the Geologists' Association, 119: 59-72.

Van Konijnenburg-Van Cittert, J.H.A., Van der Burgh, J., 1989. The flora from the Kimmeridgian (Upper Jurassic) of Culwoger, Sutherland, Scotland. Review of Palaeobotany and Palynology, 61: 1-51.

Van der Schootbrugge, B., Quan, T.M., Lindström, S., Püttmann, W., Heunisch, C., Pross, J., Fiebig, J., Petschick, R., Röhling, H.G., Richoz, S., Rosenthal, Y., Falkowski, P.G. 2009. Floral changes across the Triassic/Jurassic boundary linked to flood basalt volcanism. Nature Geosciences, 2: 589-594.

Van der Zwan, C.J., Spaak, P., 1992. Lower to Middle Triassic sequence stratigraphy and climatology of the Netherlands, a model. Palaeogeography, Palaeoclimatology, Palaeoecology, 91: 277-290.

Visscher, H., Van der Zwan, C.J., 1981. Palynology of the Circum-Mediterranean Triassic: phytogeographical and palaeoclimatological implications. Geologische Rundschau, 70: 625-634.

Visscher, H., Brugman, W.A., Van Houte, M., 1993 Chronostratigraphical and sequence stratigraphical interpretation of the palynomorph record from the Muschelkalk of the Obernsees well, South Germany. Sonderbände der Gesellschaft für Naturkundein Württemberg, 2: 145-152.

Visscher, H., Van Houte, M., Brugman, W.A., 1994. Rejection of a Carnian (Late Triassic) "pluvial event" in Europe. Review of Palaeobotany and Palynology, 83: 217-226.

Wagner, R., ed., 2008. Tabela stratygraficzna Polski. Polska pozakarpacka (in Polish). Państwowy Instytut Geologiczny, Warszawa.

Wang, Z., Wang, L., 1990. Late Triassic fossil plants from upper part of the Shiqianfeng Group in North China. Shanxi Geology, 5: 195-212.

Yaroshenko, O.P., 1975. Morphology of the spores of Pleuromeia rossica and Densoisporites nejburgii. Paleontological Journal, 3: 101-106.

Yaroshenko, O.P., 1977. Palynology and phytogeography of the Early Triassic. Paleontological Journal, 3: 168-177.

Zharkov, M.A., Chumakov, N.M., 2001. Palaeogeography and sedimentation settings during Permian-Triassic reorganizations in biosphere. Stratigraphy and Geological Correlation, 9: 340-363.

Ziegler, A.M., Parrish, J.M., Jiping, Y., Gyllenhaal, E.D., Rowley, D.B., Parrish, J.T., Shangyou, N., Bekker, A., Hulver, M.L., 1994. Early Mesozoic phytogeography and climate. In: Palaeoclimates and Their Modeling (eds. J.R.L. Allen, B.J. Hoskins, B.W. Sellwood, R.A. Spicer and P.J. Valdes): 89-99. Chapman and Hall, London/New York/Tokyo. 